\title{
RECEIVED
}

NOV $O 11996$

OAK RIDGE

NATIONAL

OSTI

LABORATORY
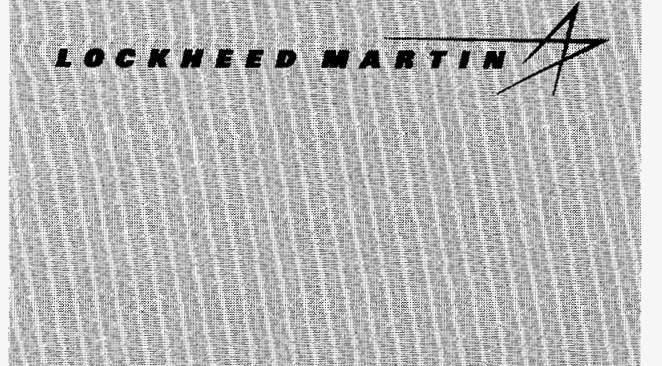

M:

1.

(y)

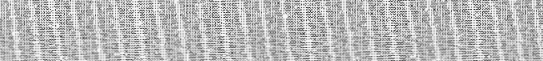

1.1)

the

(i)

1.

t)

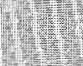

1)

).

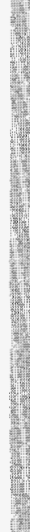

WANAGED AND OPERATED BY

LOCKHEED WARTIN ENERGY RESEARCH CORPORATION FOA THE UUTED STATES

DEPAMIMIET OF ENEREY

ORNL-27 (3-96)
S. M. Bowman

T. Suto

T. Suto

\section{Scale-4 Analysis of Pressurized Water Reactor Critical Configurations: Volume 5-North Anna Unit 1 Cycle 5}

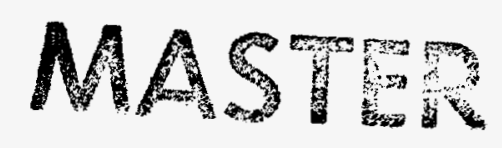


This report has been reproduced directly from the best available copy.

Available to DOE and DOE contractors from the Office of Scientific and Technical Information, P. O. Box 62, Oak Ridge, TN 37831; prices available from (423) 576-8401, FTS 626-8401.

Available to the public from the National Technical Information Service, U.S. Department of Commerce, 5285 Port Royal Road, Springfield, VA 22161.

This report was prepared as an account of work sponsored by an agency of the United States Government. Neither the United States Government nor any agency thereof, nor any of their employees, makes any warranty, express or implied, or assumes any legal liability or responsibility for the accuracy, completeness, or usefulness of any information, apparatus, product, or process disclosed, or represents that its use would not infringe privately owned rights. Reference herein to any specific commercial product, process, or service by trade name, trademark, manufacturer, or otherwise, does not necessarily constitute or imply its endorsement, recommendation, or favoring by the United States Government or any agency thereof. The views and opinions of authors expressed herein do not necessarily state or reflect those of the United States Government of any agency thereof. 
Computational Physics and Engineering Division

\title{
SCALE-4 ANALYSIS OF PRESSURIZED WATER REACTOR CRITICAL CONFIGURATIONS: VOLUME 5-NORTH ANNA UNIT 1 CYCLE 5
}

\author{
S. M. Bowman and T. Suto*
}

Date Completed: October 1994

Date Published: October 1996

\begin{abstract}
*Power Reactor and Nuclear Fuel Development Corporation, Tokyo, Japan; work performed while on assignment at ORNL.
\end{abstract}

\author{
Prepared for \\ Sandia National Laboratories \\ under Memorandum Purchase Orders 66-0162 and AD-4072 \\ with Oak Ridge National Laboratory
}

DISTRIDUTION OF THIS DOCUMENT IS UNLIMTTED

\author{
Prepared by the \\ OAK RIDGE NATIONAL LABORATORY \\ MASTER \\ managed by \\ LOCKHEED MARTIN ENERGY RESEARCH CORP. \\ for the \\ U.S. DEPARTMENT OF ENERGY \\ under contract DE-AC05-96OR22464
}

DISCLAIMER

\begin{abstract}
This report was prepared as an account of work sponsored by an agency of the United States Government. Neither the United States Government nor any agency thereof, nor any of their employees, makes any warranty, express or implied, or assumes any legal liability or responsibility for the accuracy, completeness, or usefulness of any information, apparatus, product, or process disclosed, or represents that its use would not infringe privately owned rights. Reference herein to any specific commercial product, process, or service by trade name, trademark, manufacturer, or otherwise does not necessarily constitute or imply its endorsement, recommendation, or favoring by the United States Government or any agency thereof. The views and opinions of authors expressed herein do not necessarily state or reflect those of the United States Government or any agency thereof.
\end{abstract}




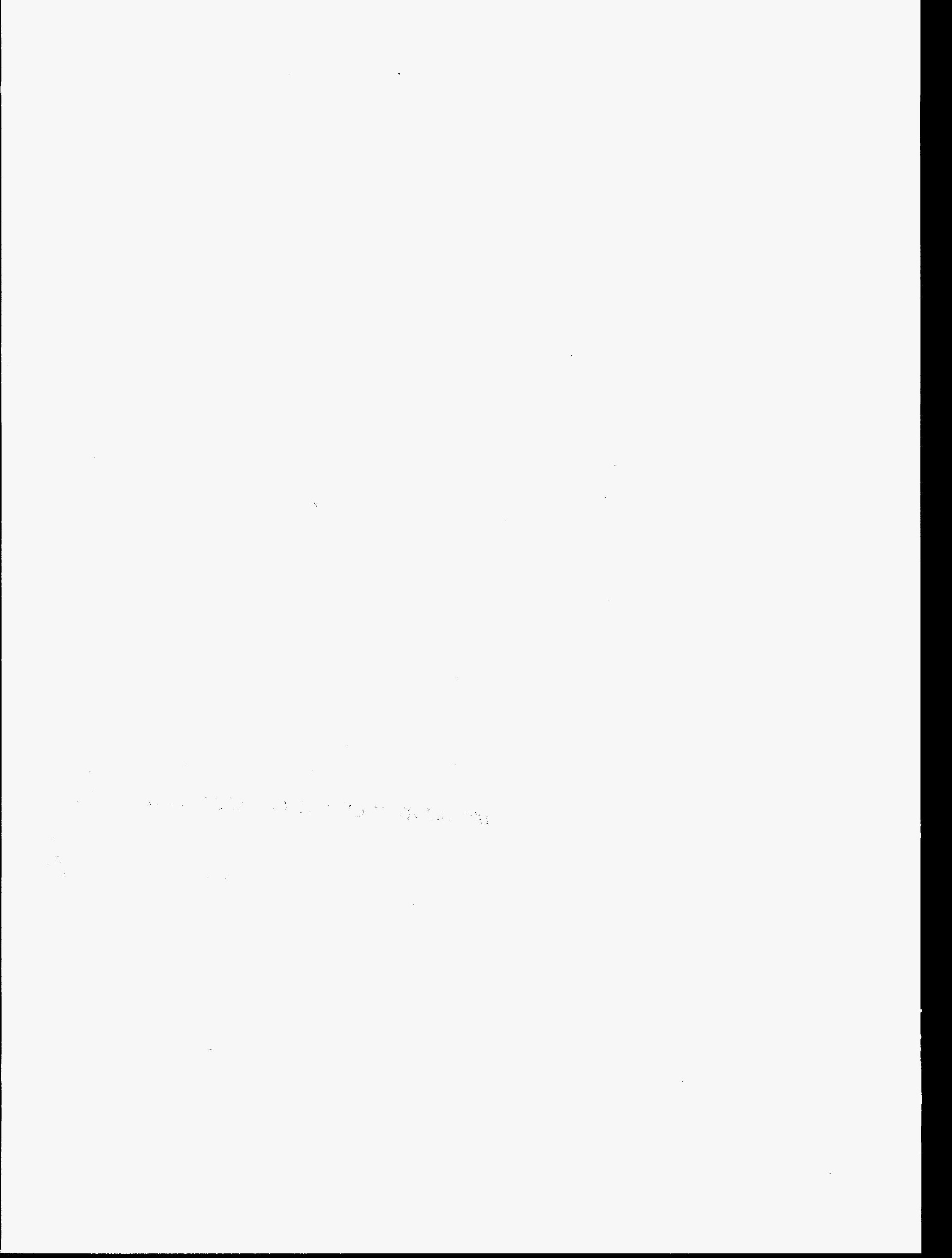




\section{DISCLAIMER}

Portions of this document may be illegible in electronic image products. Images are produced from the best available original document. 


\section{CONTENTS}

Page

LIST OF FIGURES $\ldots \ldots \ldots \ldots \ldots \ldots \ldots \ldots \ldots \ldots \ldots \ldots \ldots \ldots \ldots \ldots \ldots \ldots$

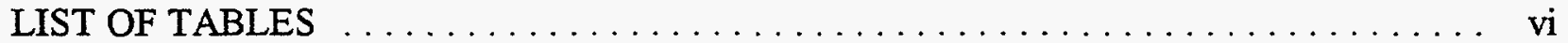

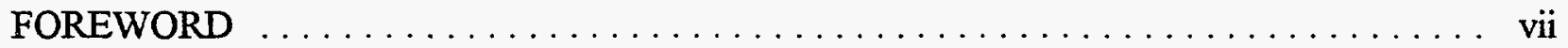

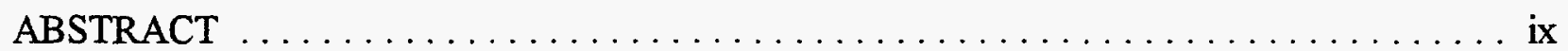

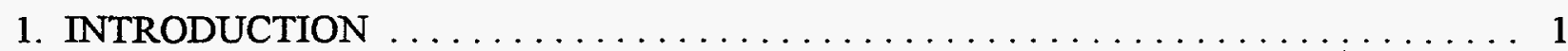

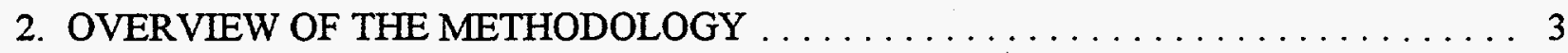

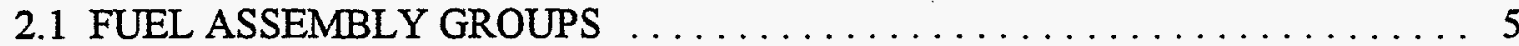

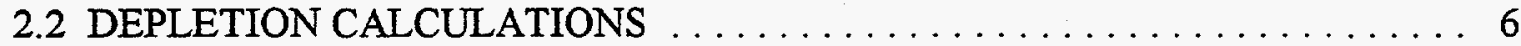

2.3 NUCLIDE CONCENTRATIONS FOR REACTOR CRITICALITY

CALCULATIONS . . . . . . . . . . . . . . . . . . . . . . 9

2.4 CROSS-SECTION PROCESSING BY CROSS-SECTION SET $\ldots \ldots \ldots \ldots 10$

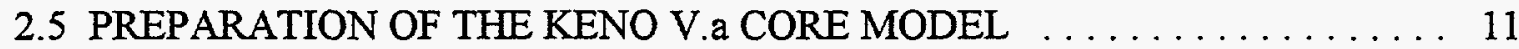

3. PREPARATION OF THE NORTH ANNA 1 CYCLE 5 CORE MODEL . . . . . . . . 13

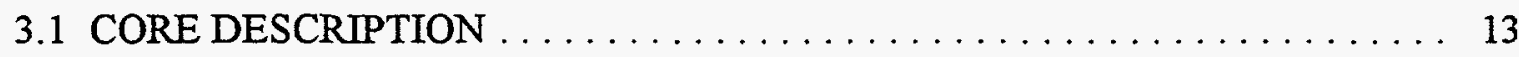

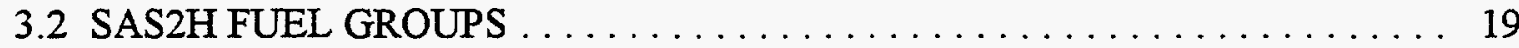

3.2.1 SAS2H Fuel Cell Without BPRs . . . . . . . . . . . . . . 21

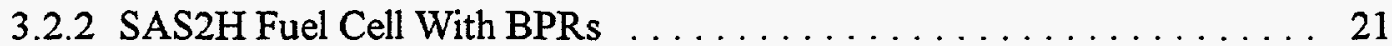

3.3 SIMILAR-BURNUP SUBGROUPING FOR CROSS-SECTION SETS . . . . . 23

3.4 SAS2H DEPLETION CALCULATIONS $\ldots \ldots \ldots \ldots \ldots \ldots \ldots \ldots \ldots$

3.5 BURNUP-DEPENDENT INTERPOLATION OF ISOTOPICS $\ldots \ldots \ldots \ldots .27$

3.5 .1 Assembly Isotopics . . . . . . . . . . . . . . . . . . . . 29

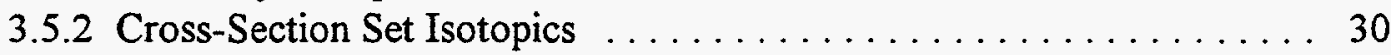

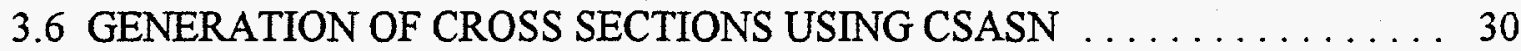

3.7 COMBINING CROSS-SECTION-SET LIBRARIES USING WAX $\ldots \ldots \ldots 30$

3.8 VALIDATION OF CROSS-SECTION SET ASSUMPTIONS $\ldots \ldots \ldots \ldots 31$

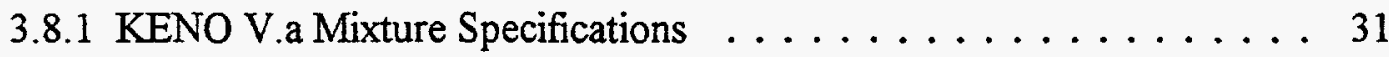

3.8.2 KENO V.a Geometry Specifications $\ldots \ldots \ldots \ldots \ldots \ldots \ldots \ldots$

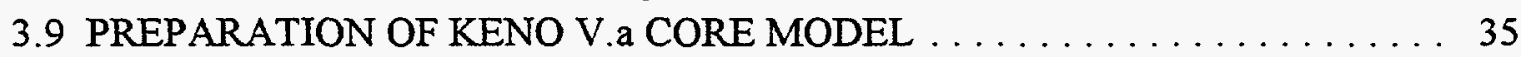

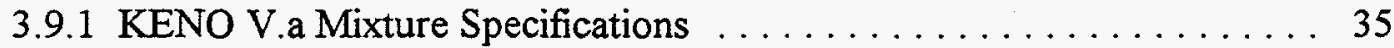

3.9.2 KENO V.a Geometry Specifications $\ldots \ldots \ldots \ldots \ldots \ldots \ldots \ldots . \ldots \ldots$

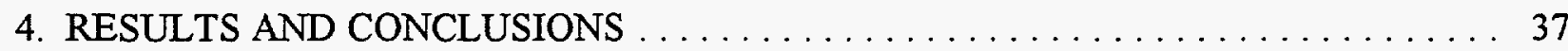

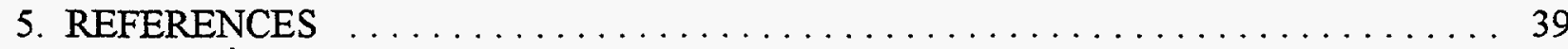


APPENDIX A. NORTH ANNA UNIT 1 CYCLE 5 DATA . . . . . . . . . . . . 43

APPENDIX B. SAS2H CASE INPUT LISTING $\ldots \ldots \ldots \ldots \ldots \ldots \ldots \ldots \ldots \ldots .47$

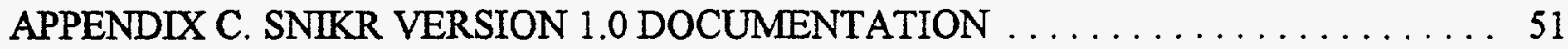

C.1 SNIKR VERSION 1.0 USER'S INPUT GUIDE $\ldots \ldots \ldots \ldots \ldots \ldots 52$

C. 2 SNIKR1 FORTRAN LISTING $\ldots \ldots \ldots \ldots \ldots \ldots \ldots \ldots, 55$

C.3 SNIKR3 FORTRAN LISTING $\ldots \ldots \ldots \ldots \ldots \ldots \ldots \ldots \ldots 69$

C.4 SNIKR INPUT LISTING FOR SPENT FUEL ISOTOPICS . . . . . 79

C.5 SNIKR INPUT LISTING FOR DEPLETED BP ISOTOPICS . . . . . 80

C.6 SAMPLE SNIKR OUTPUT $\ldots \ldots \ldots \ldots \ldots \ldots \ldots \ldots \ldots . \ldots 1$

APPENDIX D. CSASN INPUT LISTINGS $\ldots \ldots \ldots \ldots \ldots \ldots \ldots \ldots \ldots \ldots \ldots .87$

D. 1 CSASN INPUT LISTING FOR CROSS-SECTION SET $3 \ldots \ldots \ldots 88$

D. 2 CSASN INPUT LISTING FOR CROSS-SECTION SET $4 \ldots \ldots \ldots 89$

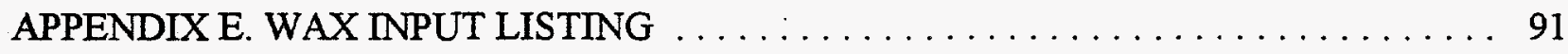

APPENDIX F. KENO V.a INPUT LISTING $\ldots \ldots \ldots \ldots \ldots \ldots \ldots \ldots \ldots \ldots$ 


\section{LIST OF FIGURES}

Figure

Page

1. Overview of the reactor critical calculation procedure. $\ldots \ldots \ldots \ldots \ldots \ldots$

2. SAS2H burnup model of assemblies within a fuel group $\ldots \ldots \ldots \ldots \ldots \ldots$

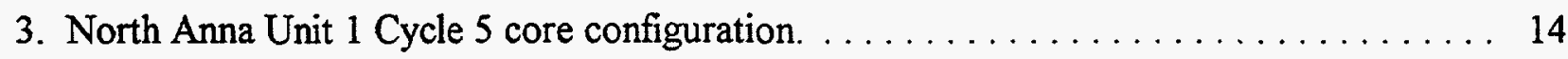

4. Fuel assembly lattice arrangements in North Anna Unit 1 Cycle $5 \ldots \ldots \ldots$

5. North Anna Unit 1 Cycle 5 burnable poison loading configuration $\ldots \ldots \ldots \ldots$

6. North Anna Unit 1 eighth-core symmetric configuration $\ldots \ldots \ldots \ldots \ldots \ldots$

7. Full-core-assembly positions and core baffle configuration $\ldots \ldots \ldots \ldots \ldots \ldots$

8. KENO V.a unit definitions based on component arrays $\ldots \ldots \ldots \ldots \ldots \ldots \ldots$

9. $\mathrm{BOC}, \mathrm{HZP}$ eighth-core relative fission density distribution $\ldots \ldots \ldots \ldots \ldots \ldots$

A.1. North Anna Unit 1 Cycle 5 core loading pattern $\ldots \ldots \ldots \ldots \ldots \ldots$ 


\section{LIST OF TABLES}

Table

Page

1. Nuclides updated by $\mathrm{SAS} 2 \mathrm{H} \ldots \ldots \ldots \ldots \ldots \ldots \ldots \ldots \ldots \ldots \ldots \ldots \ldots$

2. Set of fuel nuclides used in KENO V.a calculations $\ldots \ldots \ldots \ldots \ldots \ldots \ldots \ldots \ldots$

3. North Anna PWR Unit 1 assembly design description $\ldots \ldots \ldots \ldots \ldots \ldots$

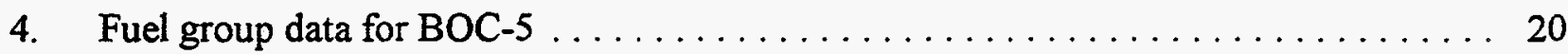

5. Initial uranium isotopic content of fresh fuel $\ldots \ldots \ldots \ldots \ldots \ldots \ldots \ldots \ldots \ldots \ldots$

6. Light-element masses used in $\mathrm{SAS} 2 \mathrm{H}$ calculations $\ldots \ldots \ldots \ldots \ldots \ldots \ldots$

7. Borosilicate glass composition in BPR assemblies $\ldots \ldots \ldots \ldots \ldots \ldots \ldots$

8. Borosilicate glass input atom densities $\ldots \ldots \ldots \ldots \ldots \ldots \ldots \ldots \ldots \ldots \ldots$

9. Effective fuel cells with BPRs $\ldots \ldots \ldots \ldots \ldots \ldots \ldots \ldots \ldots \ldots \ldots \ldots \ldots$

10. Fuel assembly data for eighth-core geometry $\ldots \ldots \ldots \ldots \ldots \ldots \ldots \ldots$

11. Cross-section sets for one-eighth-core assemblies $\ldots \ldots \ldots \ldots \ldots \ldots \ldots \ldots$

12. Cross-section sets for North Anna Unit 1 Cycle 5 BOC $\ldots \ldots \ldots \ldots \ldots \ldots \ldots$

13. SAS2H operating history data by fuel group and cycle $\ldots \ldots \ldots \ldots \ldots \ldots \ldots$

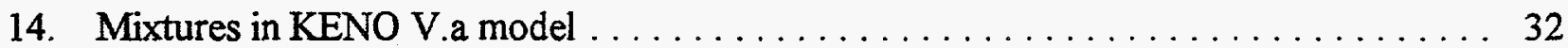

15. Unit numbers used in North Anna KENO V.a core model $\ldots \ldots \ldots \ldots \ldots \ldots \ldots$

A.1 Fuel assembly burnups at BOC for North Anna Unit 1 Cycle $5 \ldots$. . . . . . . . 45 


\section{FOREWORD}

The work described in this report was performed under a quality assurance (QA) program consistent with DOE/RW-214, "Quality Assurance Requirements," as directed by Sandia National Laboratories (SNL) Contract 66-0162. Specifically, work was performed under the QA plan developed in 1992 at Oak Ridge National Laboratory (ORNL) and documented in ORNL QA records as document BCAV-QAAP-002. The analyses, computer codes, and documentation that served as a basis for this report were produced, reviewed, and controlled as per the requirements of the ORNL QA plan. Subsequent documentation of the work in the form of this report was performed under an OCRWM-approved QA program, consistent with DOE/RW-0333P, "Quality Assurance Requirements and Descriptions," as stipulated in SNL Contract No. AD-4072.

Reactor design and burnup cycle data used in this work were obtained primarily from the North Anna Unit 1 Cycle 5 design report, issued by Virginia Electric and Power Company. Core design reports are mandated by the Nuclear Regulatory Commission (NRC); parameters described in the report serve as the basis for startup testing. Use of such data in startup procedures is in accordance with NRC requirements. Thus although the data contained in the core design report are not explicitly qualified under the OCRWM program, they are considered to be consistent with the nature of qualified data under OCRWM QA procedures, and are therefore considered to be appropriate for use in this work. 


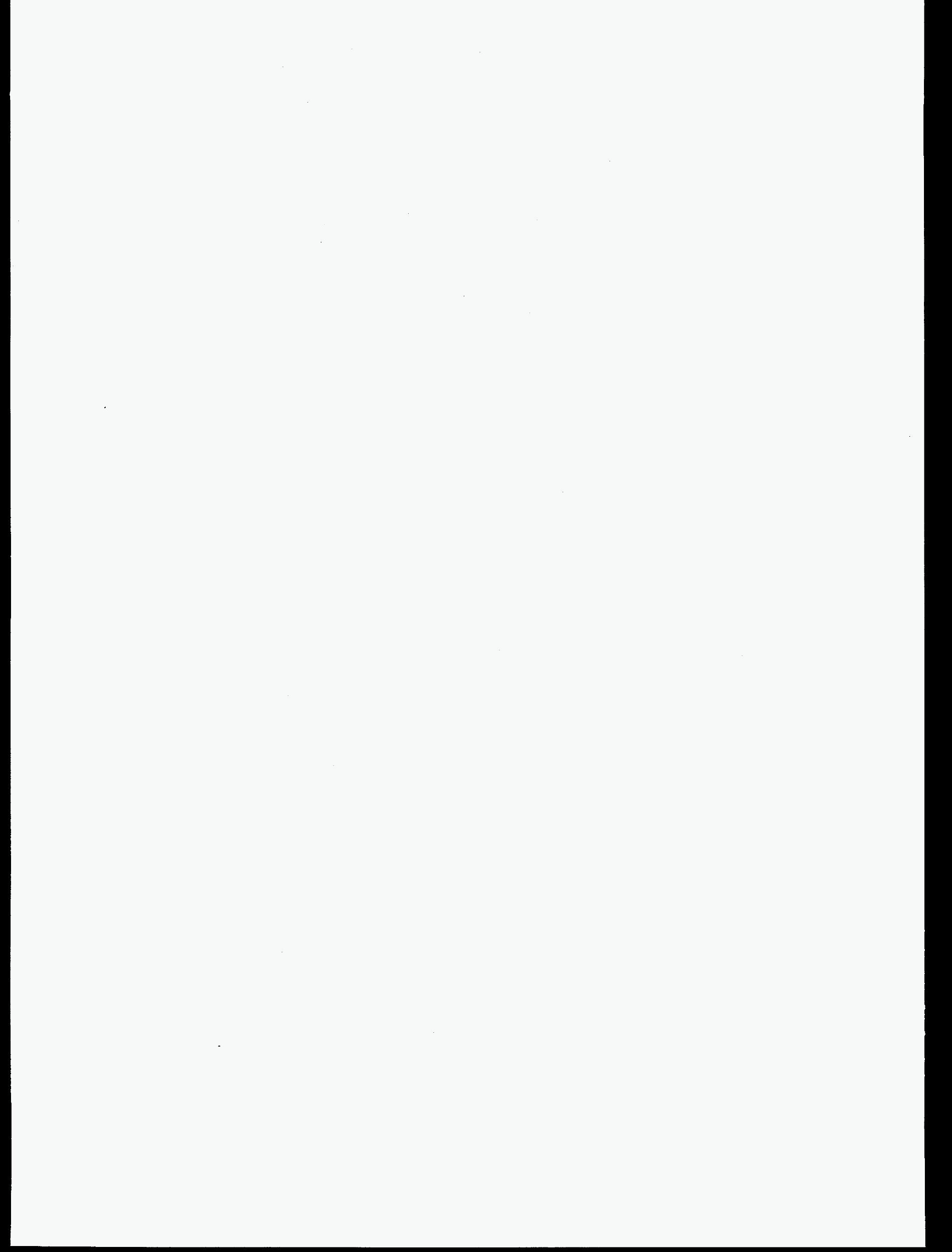




\begin{abstract}
The requirements of ANSI/ANS 8.1 specify that calculational methods for away-fromreactor (AFR) criticality safety analyses be validated against experimental measurements. If credit for the negative reactivity of the depleted (or spent) fuel isotopics is desired, it is necessary to benchmark computational methods against spent fuel critical configurations. This report summarizes a portion of the ongoing effort to benchmark AFR criticality analysis methods using selected critical configurations from commercial pressurized-water reactors (PWR).

The analysis methodology selected for all calculations reported herein was the codes and data provided in the SCALE-4 code system. The isotopic densities for the spent fuel assemblies in the critical configurations were calculated using the SAS2H analytical sequence of the SCALE-4 system. The sources of data and the procedures for deriving SAS2H input parameters are described in detail. The SNIKR code module was used to extract the necessary isotopic densities from the SAS2H results and to provide the data in the format required by the SCALE criticality analysis modules. The CSASN analytical sequence in SCALE-4 was used to perform resonance processing of the cross sections. The KENO V.a module of SCALE-4 was used to calculate the effective multiplication factor $\left(\mathrm{k}_{\text {eff }}\right)$ of each case. The SCALE-4 27-group burnup library containing ENDF/BIV (actinides) and ENDF/B-V (fission products) data was used for all the calculations.

This volume of the report documents the SCALE system analysis of one reactor critical configuration for North Anna Unit 1 Cycle 5. This unit and cycle were chosen for a previous analysis using a different methodology because detailed isotopics from multidimensional reactor calculations were available from the Virginia Power Company. These data permitted comparison of criticality calculations directly using the utility-calculated isotopics to those using the isotopics generated by the SCALE-4 SAS2H sequence. This reactor critical benchmark has been reanalyzed using the methodology described above. The benchmark critical calculation was the beginning-ofcycle (BOC) startup at hot, zero power (HZP). The $\mathrm{k}_{\text {eff }}$ result was 1.0040 , with a standard deviation of 0.0005 .
\end{abstract}




\section{INTRODUCTION}

In the past, criticality analysis of pressurized-water-reactor (PWR) fuel in storage or transport has assumed that the fuel is fresh with the maximum allowable initial enrichment. This assumption has led to the design of widely spaced and/or highly poisoned storage and transport arrays. If credit is assumed for fuel burnup, more compact and economical arrays can be designed. Such reliance on the reduced reactivity of spent fuel for criticality control is referred to as "burnup credit." If burnup credit is applied in the design of a cask for use in the transport of spent light-water-reactor (LWR) fuel to a repository, a significant reduction both in the cost of transport and in the risk to the public can be realized. ${ }^{1}$ These benefits caused the U.S. Department of Energy (DOE) to initiate a program to investigate the technical issues associated with burnup credit in spent fuel cask design. These efforts have been led by Sandia National Laboratories (SNL) and carried out as part of the Cask Systems Development Program within the Office of Civilian Radioactive Waste Management. This five-volume report documents work performed at Oak Ridge National Laboratory (ORNL) as part of a larger effort to demonstrate an acceptable approach for validating computational tools to be used in burnup credit cask design.

The computational tools of interest for burnup credit cask design are initially those currently used and accepted for spent fuel characterization (prediction of isotopics) and criticality safety (prediction of the effective multiplication factor, $\mathrm{k}_{\text {eff }}$ ) in away-from-reactor (AFR) applications. The criticality analysis tools accepted for fresh fuel cask design have typically been validated per the requirements of the ANSV/ANS-8.1 criticality safety standard ${ }^{2}$ (i.e., comparison against experimental data). Numerous critical experiments for fresh PWR-type fuel in storage and transport configurations exist and can be used as part of a validation data base. However, there are no critical experiments with burned PWR-type fuel in storage and transport configurations that can be directly used to extend the data base to the realm of burned fuel. Thus as part of the effort to extend the validation of existing criticality analysis tools to the domain of burned fuel, it was decided to investigate the performance of AFR analysis methods in the prediction of measured reactor critical configurations. Even though elements of a reactor critical analysis do not directly correspond to analyses of spent fuel assemblies in transportation and storage casks (e.g., elevated temperatures in reactor configurations or poison plates in cask designs), comparison against measured critical configurations can be used to validate aspects of spent fuel cask configurations that are not addressed in other experiments (i.e., fission-product interactions and the prediction of time-dependent actinide and fission-product inventories). Reactor critical configurations contain a diverse range of nuclides, including fissile and fertile actinides, fission products, and activation products. Thus nuclear reactor core criticals can be used to test the ability of an analysis methodology to generate accurate burned fuel isotopics and handle the reactivity effects of complex heterogeneous systems containing burned fuel.

To date, the SCALE code system ${ }^{3}$ developed at ORNL has been the primary computational tool used by DOE to investigate technical issues related to burnup credit. ${ }^{4}$ SCALE is a wellestablished code system that has been widely used in AFR applications for spent fuel characterization via the SAS2H/ORIGEN-S analysis sequence ${ }^{s}$ and criticality safety analyses via the CSAS/KENO V.a analysis sequence. ${ }^{6}$ The isotopic composition of the spent fuel is derived from a SAS2H/ORIGEN-S calculation that simulates two-dimensional (2-D) effects in a one-dimensional (1-D) model of an LWR 
fuel assembly. The depletion model is a spatially independent point model using cross sections and neutron flux parameters derived from the 1-D fuel assembly model. The KENO V.a Monte Carlo $\operatorname{code}^{7}$ is used to calculate the neutron multiplication factor for complex multidimensional systems. KENO V.a has a large degree of flexibility in its geometrical modeling capabilities which enables spent fuel arrays and container geometries to be modeled in explicit detail. The SCALE-4 27-group burnup library containing ENDF/B-IV (actinides) and ENDF/B-V (fission products) data was used for all calculations.

Early efforts to analyze reactor criticals ${ }^{8}$ using the SCALE modules concentrated on using utility-generated isotopic data, although some analyses were performed using isotopics calculated with SAS2H. Based on this initial work, a consistent SCALE-based analysis methodology that simplifies both the data requirements and the calculational procedure was developed. The criteria used to select the reactor critical configurations were (1) applicability to the PWR fuel to be used in burnup credit cask design (e.g., long downtimes for decay of short-lived isotopes, large percentages of burned fuel in the configuration); (2) the need to verify consistency in calculated results for different reactor conditions; and (3) the need to provide a comparison with the results of ref. 8. Acceptable performance of the SCALE system in the prediction of $k_{\text {eff }}$ will be judged relative to established SCALE performance for fresh fuel systems. If agreement is seen within the range typical for fresh fuel systems, then it will be concluded that the methodology described herein is valid in terms of its treatment of depletion and decay calculations and fission-product interactions, within the range of application defined by the reactor conditions.

The purpose of this volume of the report is to describe the reanalysis of the hot, zero power (HZP) reactor critical configuration obtained during beginning-of-cycle (BOC) startup physics testing for Virginia Power's North Anna Unit 1 Cycle 5. This unit was previously analyzed in ref. 8, along with a hot, full-power (HFP) BOC configuration. It has since been determined that the HFP case was not an actual measured critical configuration, but merely a calculated critical configuration generated by the utility's reactor physics codes. These two cases were originally selected because of the availability of the operating data and the three-dimensional (3-D) calculated nuclide density distributions from the utility's reactor physics calculations. Differences of approximately $2 \% \Delta \mathrm{k}$ were observed between the results of the original and revised methodologies in the reanalysis of Surry Unit 1 Cycle 2 in Vol. 3 of this report. To investigate these differences further, the North Anna BOC, HZP reactor critical has been reanalyzed using the revised SCALE methodology.

Section 2 of this volume presents an overview of the methodology employed in the reactor critical analyses. Section 3 provides the details of the analysis performed for North Anna 1 Cycle 5. The results and conclusions are discussed in Sect. 4. 


\section{OVERVIEW OF THE METHODOLOGY}

An essential part of any analysis validation effort is to use the same codes, input options, and technical approach for the validation study as that used for the application. To this end, a straightforward calculational strategy was established that minimizes the data required to characterize the spent fuel and is appropriate for use by a cask designer performing criticality analysis for spent fuel assemblies.

The methodology applied in reactor critical analyses can be broken into five steps: (1) grouping of fuel assemblies into similar-content groups and similar-burnup subgroups; (2) calculation of burnup-dependent isotopics for each group; (3) interpolation of decay calculations from results of the previous step to obtain both individual assembly and subgroup isotopics; (4) cross-section processing based on subgroup isotopics; and (5) preparation of a KENO V.a model based on the actual core geometry, individual assembly isotopics, and subgroup-evaluated cross sections. The model developed in step 5 is used to calculate the effective multiplication factor, $\mathrm{k}_{\text {eff }}$ for the reactor.

Figure 1 provides a graphical overview of these steps, showing the relationships between the data and codes used in each stage of the calculation. The first step shown in the figure represents the process of collecting assembly information from reactor documentation. Eighth-core symmetry is assumed to reduce the number of unique assemblies modeled such that the burnup of each assembly in an eighth-core segment represents the average burnup of all assemblies located in the corresponding symmetric position across the core. Using the reactor information, "groups" of assemblies are identified which are of cognate background (i.e., same initial loading and burn cycles). These assembly groups are then further categorized into "subgroups" consisting of assemblies within a group with similar ( $\pm 2 \mathrm{GWd} / \mathrm{MTU}$ ) burnups.

The second step shown in Fig. 1 involves the calculation of isotopic contents using the decay and depletion steps of the SAS2H calculational sequence of SCALE. Calculations are performed for each assembly group based on the initial fresh fuel content and operating history of the group. Output consists of calculated isotopic contents for each of a number of user-specified timesteps.

In step three, the SNIKR code package (not a part of the SCALE system) is used to interpolate between isotopics for appropriate timesteps to obtain the assembly-specific isotopic contents for each assembly to be used in the KENO V.a core model. (SNIKR is a simple tool used to automate the task of extracting, interpolating, and formatting data; however, this process can be performed manually.) SNIKR is also used to calculate the isotopics for the average burnup of each assembly subgroup.

The results of step three are used in step four to create fuel pin models based on the average composition of an assembly subgroup; the CSASN sequence in SCALE is used to calculate the problem-dependent, group-weighted cross sections for each subgroup. The SCALE WAX module combines all subgroup-based cross sections into a single working library where cross-section identifiers are assigned such that each numeric identifier indicates both a specific isotope and the subgroup upon which it was based.

Finally, in step five a KENO V.a model is created based on the core geometry, again assuming eighth-core symmetry. Thus even though a full-core model is prepared, each eighth-core segment of the core is identical in composition to the other eighth-core segments. (A full-core model in KENO V.a is more computationally efficient than an eighth-core model with reflective boundary 


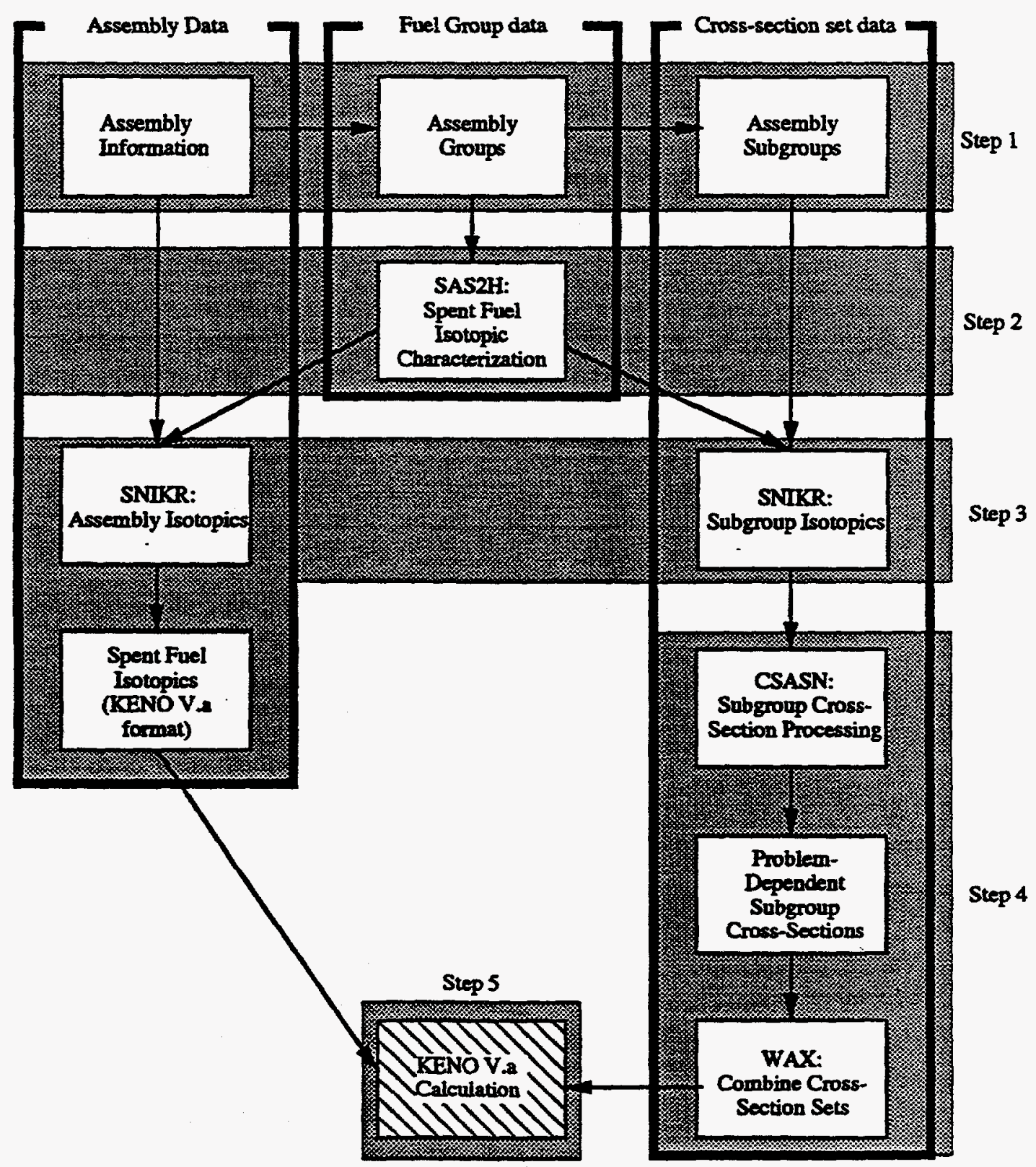

Fig. 1. Overview of the reactor critical calculation procedure. 
conditions.) Fuel assemblies are assumed to be uniform in composition (all fuel pins are comprised of the same material), and isotopics are obtained from the burnup-specific results obtained in step 3 . Assembly isotopes are assigned cross-section identifiers corresponding to the appropriate subgroupbased cross sections derived in step 4 . Remaining core information is obtained from the reactor documentation. Calculations are then performed to determine the value of $\mathrm{k}_{\text {eff }}$ for the reactor model and to verify that the solution has converged.

The specifics of each of the steps described above are discussed in detail in each of the following sections.

\subsection{FUEL ASSEMBLY GROUPS}

Since many assemblies in a reactor begin with identical initial compositions and experience simultaneous operating histories, these similar fuel assemblies can be collected effectively into groups with one depletion calculation performed for each group. It is assumed that at a given burnup, all assemblies within a group have the same isotopic content. If the isotopic content of a group is known as a function of burnup, then one can interpolate to obtain the specific isotopics for a given assembly burnup. This interpolation is discussed further in Sect. 2.3.

A minimum granularity for grouping is to collect fuel assemblies by reactor fuel batch. In the nomenclature generally applied by commercial PWR core designers, a fuel batch is typically comprised of a single enrichment fuel, all loaded at the same time, and all residing in-core for the same fuel cycles. Three fuel batches (i.e., enrichments) are usually present in the first operating cycle of a reactor. These batches are typically designated by the numbers 1,2 , and 3 . Prior to each subsequent cycle of operation, one new batch of fuel is usually added and some of the depleted fuel assemblies are removed. Each new batch of fuel is assigned a number unique to that reactor. If the new fuel assemblies to be loaded consist of more than one enrichment, they may be assigned as a "split batch," using the same number with a different letter appended to each enrichment. For example, if two enrichments were to be added to Cycle 2, the fuel assemblies of one enrichment would be designated as batch $4 \mathrm{~A}$, and those of the other enrichment would be designated as batch 4B. Hence if a given batch of assemblies has experienced identical operating periods, downtimes, and roughly the same power history, the batch meets the minimum requirements for a calculational fuel group. However, within a given fuel batch, additional fuel groups (i.e., separate depletion calculations) may be required when absorber materials [i.e., burnable poison rods (BPRs) or control rods] are present in certain assemblies within a fuel batch.

As discussed, within a fuel group it is possible to interpolate between a series of burnups to determine the isotopic concentrations corresponding to a specific burnup. This interpolation procedure can be used to calculate the contents of each individual assembly. Based on these assembly isotopics, it is possible to generate a content-specific cross-section set for each assembly. However, since nuclide cross sections vary slowly with burnup (after the initial startup of approximately $150 \mathrm{MWd} / \mathrm{MTU}$ ) the analysis methodology can be accurately simplified by preparing problemdependent cross sections for a set of similar assemblies with similar burnups. Unfortunately, because of specific power variations related to the assembly locations in the core, it is possible to have a relatively wide range of burnups within a single fuel group. Thus it may be necessary to divide fuel groups into subgroups or cross-section sets based on burnup such that all assemblies included in a 
cross-section set are within a limited burnup range; the number of cross-section sets will depend on the range of burnups contained in the fuel group. Previous work ${ }^{8}$ has indicated that cross-section sets with burnup ranges of no more than $2 \mathrm{GWd} / \mathrm{MTU}$ can be adequately represented by the average burnup value within the cross-section set.

\subsection{DEPLETION CALCULATIONS}

Depletion calculations were performed using the SAS2 $\mathrm{H}^{5}$ sequence of the SCALE-4 code system and the 27 -group burnup library. The SAS2H sequence invokes the ORIGEN-S ${ }^{9}$ code to perform depletion and decay calculations. The SAS2H procedure uses a 1-D two-part spectrum calculation (part 1 is a pin-cell model, part 2 is an assembly model) at selected times in the irradiation history to generate burnup-dependent cross sections based on the given design and operating parameters. At the end of each burnup step, cross sections for default and any user-specified isotopes are reevaluated based on the new isotopic composition. The purpose of these calculations is to predict the isotopic content of each fuel group as a function of its operating history. For fuel groups comprised of fresh (unburned) fuel at the time of the critical measurements, SAS2H calculations are not necessary; the isotopic content is based on that of the fresh fuel specifications.

Although it is necessary to model the presence of BPRs for the cycle for which the criticality calculation is to be performed, previous studies ${ }^{10,11}$ have shown that the history of the assembly with respect to the insertion and removal of BPRs in earlier reactor cycles is small enough to be neglected $(<1 \% \Delta \mathrm{k} / \mathrm{k})$. To model the influence of the BPRs in the cycle of interest, an effective cell is derived. This effective cell conserves the mass of the nuclides comprising the BPRs, guide tube, and fuel rods. In this effective cell, the densities of the isotopes remain unchanged, but the rod diameters of the glass and stainless steel in the BPRs are modified appropriately for the 1-D assembly model required by SAS2H.

Since, within a fuel group, it is assumed that isotopic content is a function only of burnup, it is possible to calculate the content of the fuel at a given burnup by interpolation between SAS2H/ORIGEN-S isotopics provided at each burnup step. The manner of interpolation is discussed in the following subsection. SAS2H provides the capability to obtain the isotopic composition of a fuel at specified burnup intervals given the initial composition of the fuel, clad, and moderator, design parameters of the fuel rod and lattice, and power history. To provide sufficient points for interpolation, the burnup history was broken into equal intervals of no more than $5 \mathrm{GWd} / \mathrm{MTU}$. (This interval should not be confused with the 2-GWd/MTU interval used to establish assembly subgroups. The 5-GWd/MTU interval represents an interpolation range over which isotopic concentrations are assumed to vary smoothly.) The fuel groups were depleted at least 1.2 times the maximum burnup $\left(\mathrm{B}_{\max }\right)$ of the fuel group. Note that it is generally sufficient to calculate burnups out to the maximum burnup in a group, as this will bound all burnups in the group. A value of $1.2 * \mathrm{~B}_{\max }$ was used to allow for the capability of modeling axial burnup variations where volume-averaged center region burnups may be up to 1.2 times larger than the assembly average. However, axial burnup variations are not included in the models presented in this report.

To make it possible to interpolate between burnup steps and account for downtime between cycles, a simplification is made in the burnup model. Since the burnup actually accumulated during each cycle varies for each fuel assembly in a group, the downtime was split and applied at the end of 
each burnup interval. This practice ensures that the spent fuel isotopics for all fuel assemblies contain the impact of the reactor cycle downtime when interpolation on burnup is performed. The ratio of uptime to downtime for each operating cycle was used to determine the downtime for each burnup interval. Average values for specific power were computed from the fuel group average burnups and the total uptime for the cycle. The average soluble boron concentrations were based on boron letdown curves for each operating cycle. Isotopics for assembly-specific burnups may then be obtained via interpolation between calculated isotopics at the end of each burnup interval (prior to downtime). This approach is illustrated in Fig. 2. The top portion of the picture shows the "actual" burnup histories for two hypothetical assemblies in a fuel group. Note that in this example the number of cycles and downtimes are the same but that burnup in each assembly is different within each cycle. The lower portion of the figure demonstrates how the burnup of each assembly is represented in a SAS2H depletion, using a single calculation to represent the entire fuel group. Each cycle is broken down into multiple burnup intervals, each followed by a downtime (for the first two cycles). The final cycle is calculated with a sufficient number of burnup intervals to exceed the maximum burnup ( $31 \mathrm{MWd} / \mathrm{MTU}$ in assembly A of Fig. 2) by $20 \%$. The isotopics are then available at fixed time intervals, from which interpolation can be performed for assembly-specific burnups. Note that the burnup in each of the first two cycles is selected so as to represent average cycle burnups for the group. Any downtime immediately before the reactor critical conditions was not included in the SAS2H depletion, but was explicitly modeled as described in Sect. 2.3.

As discussed earlier, group-weighted cross sections are calculated as a function of burnup within the SAS2H sequence using flux weighting performed by XSDRNPM for each specified burnup step. Cross sections are updated for a default set of isotopes built into the SAS2H sequence, plus any additional nuclides specified by the user. Table 1 shows the default set plus 44 additional actinides and fission products specified for reactor depletion cases. Also included is oxygen, which is present in significant quantities in $\mathrm{UO}_{2}$ fuel. These nuclides represent a combination of the most important nuclides for burnup credit calculations and for reactor physics calculations. The selection of burnup credit nuclides is based on availability of experimentally measured isotopic concentrations and on sensitivity studies performed for a large number of nuclides under various spent fuel transportation/storage conditions, as described in ref. 12. The reactor physics nuclides are additional isotopes that are not important in a transportation sense, but have been determined to be important for depletion, decay, and criticality calculations under reactor operating conditions (e.g., ${ }^{135} \mathrm{Xe}$ builds in rapidly during reactor operation but decays away with a 9.1-h half-life, and is therefore unimportant in 5-year-cooled spent fuel). These nuclides were identified in earlier work. ${ }^{10,13}$

Any additional cross sections required for depletion calculations are obtained from the more than 1000 nuclides available within the ORIGEN-S one-group LWR library and are adjusted with burnup using the ORIGEN-S spectral parameters (THERM, RES, and FAST) ${ }^{9}$ calculated using fluxes calculated by XSDRNPM. The ORIGEN-S one-group LWR library available in SCALE-4 has been updated to use cross sections from the SCALE-4 27-group burnup library for all 193 nuclides in that library, by extracting one-group cross sections from the output of a low-burnup, LWR-type fuel model using all burnup library nuclides as input.

Note that ORIGEN-S tracks all decay chains and does not account for the loss of volatile isotopes; however, this fact is not felt to have a significant effect on isotopic calculations. 

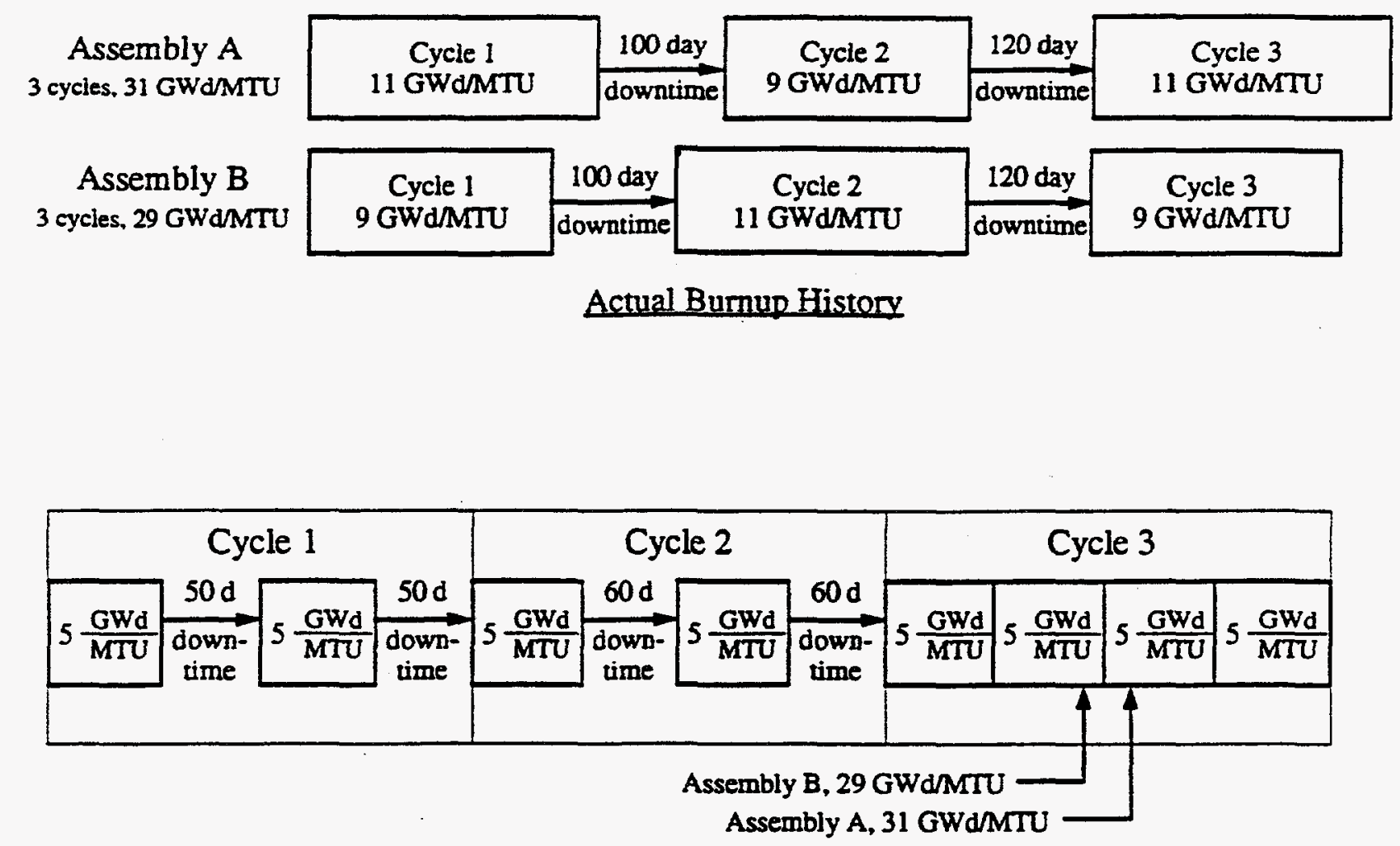

Fig. 2. SAS2H burnup model of assemblies within a fuel group. 
Table 1. Nuclides updated by SAS2H

\begin{tabular}{|c|c|c|c|c|}
\hline${ }^{234} \mathrm{U}^{a}$ & ${ }^{243} \mathrm{Am}^{a}$ & ${ }^{94} \mathrm{Nb}$ & ${ }^{132} \mathrm{Xe}$ & ${ }^{145} \mathrm{Nd}$ \\
\hline${ }^{235} \mathrm{U}^{a}$ & ${ }^{242} \mathrm{Cm}^{a}$ & ${ }^{16} \mathrm{O}^{b}$ & ${ }^{135} \mathrm{Xe}^{a}$ & ${ }^{147} \mathrm{Nd}$ \\
\hline${ }^{236} \mathrm{U}^{a}$ & ${ }^{243} \mathrm{Cm}^{a}$ & ${ }^{99} \mathrm{Tc}$ & ${ }^{136} \mathrm{Xe}$ & ${ }^{147} \mathrm{Pm}$ \\
\hline${ }^{238} \mathrm{U}^{a}$ & ${ }^{244} \mathrm{Cm}^{a}$ & ${ }^{101} \mathrm{Ru}$ & ${ }^{133} \mathrm{Cs}^{a}$ & ${ }^{148} \mathrm{Pm}$ \\
\hline${ }^{237} \mathrm{~Np}^{a}$ & ${ }^{83} \mathrm{Kr}$ & ${ }^{106} \mathrm{Ru}$ & ${ }^{134} \mathrm{Cs}$ & ${ }^{147} \mathrm{Sm}$ \\
\hline${ }^{238} \mathrm{Pu}^{a}$ & ${ }^{85} \mathrm{Kr}$ & ${ }^{103} \mathrm{Rh}$ & ${ }^{135} \mathrm{Cs}$ & ${ }^{149} \mathrm{Sm}$ \\
\hline${ }^{239} \mathrm{Pu}^{a}$ & ${ }^{90} \mathrm{Sr}$ & ${ }^{105} \mathrm{Rh}$ & ${ }^{137} \mathrm{Cs}$ & ${ }^{150} \mathrm{Sm}$ \\
\hline${ }^{240} \mathrm{Pu}^{a}$ & ${ }^{89} \mathrm{Y}$ & ${ }^{105} \mathrm{Pd}$ & ${ }^{136} \mathrm{Ba}$ & ${ }^{151} \mathrm{Sm}$ \\
\hline${ }^{241} \mathrm{Pu}^{a}$ & ${ }^{95} \mathrm{Mo}$ & ${ }^{108} \mathrm{Pd}$ & ${ }^{139} \mathrm{La}$ & ${ }^{152} \mathrm{Sm}$ \\
\hline${ }^{242} \mathrm{Pu}^{a}$ & ${ }^{93} \mathrm{Zr}$ & ${ }^{109} \mathrm{Ag}$ & ${ }^{144} \mathrm{Ce}$ & ${ }^{153} \mathrm{Eu}$ \\
\hline${ }^{241} \mathrm{Am}^{a}$ & ${ }^{94} \mathrm{Zr}$ & ${ }^{124} \mathrm{Sb}$ & ${ }^{141} \mathrm{Pr}$ & ${ }^{154} \mathrm{Eu}$ \\
\hline \multirow[t]{2}{*}{${ }^{242 \mathrm{~m}} \mathrm{Am}^{a}$} & ${ }^{95} \mathrm{Zr}$ & ${ }^{131} \mathrm{Xe}$ & ${ }^{143} \mathrm{Pr}$ & ${ }^{155} \mathrm{Eu}$ \\
\hline & & & ${ }^{143} \mathrm{Nd}$ & ${ }^{155} \mathrm{Gd}$ \\
\hline
\end{tabular}

${ }^{a}$ Automatically updated by SAS2H.

${ }^{b}$ Not an actinide or fission product, but present in $\mathrm{UO}_{2}$ fuel.

\subsection{NUCLIDE CONCENTRATIONS FOR REACTOR CRITICALITY CALCULATIONS}

As has been indicated in previous sections, the isotopic content may be determined for each assembly or cross-section set by interpolating between burnups for which SAS2H/ORIGEN-S depletion calculations have been performed, based on the final burnup of the fuel. The nuclide concentrations output at this point then represent the composition prior to shutdown or discharge. For a criticality condition obtained after the shutdown of the last cycle, it is necessary to perform decay calculations to account for the change in composition due to radioactive decay during the downtime prior to criticality.

The actual number densities used in the criticality calculations are derived from the SAS2H calculation for a given fuel batch using a newly developed interface module, SAS2H Nuclide Inventories for KENO Runs (SNIKR). This module was developed to enable the user to interpolate number densities from a SAS2H calculation as a function of burnup and to perform the necessary decay calculations to model cooling time for use in spent fuel critical calculations. SNIKR has not been incorporated into SCALE at this time; thus input descriptions and code listings have been included in Appendix C.

The current version of SNIKR has been written to be executed as a sequence of computational routines. In the first phase, SNIKR 1, burnup-dependent nuclide inventories are read from a dataset produced from a SAS2H calculation. SNIKR1 uses a Lagrangian interpolation scheme to calculate nuclide concentrations for a specified burnup. In the Lagrangian interpolation scheme, a polynomial of degree 1 less than the number of data points to be fit is used to represent the number density for each nuclide as a function of burnup. Comparisons have been made against results using nuclide concentrations calculated directly from SAS2H for a specified burnup to examine the effect 
of the interpolation procedure on pin-cell $k_{\infty}$ (i.e., 1-D infinite-lattice calculation) values. The results of these comparisons indicated agreement to within $0.1 \% \Delta \mathrm{k}$ in the $\mathrm{k}_{\infty}$ values calculated using isotopics derived from the two methods.

SNIKR1 then sets up the input needed to decay these burnup-specific isotopics to the requested cooling time using the ORIGEN-S point-depletion code. The second phase of SNIKR executes the ORIGEN-S module in the SCALE code system. Phase three, SNIKR3, reads the number densities produced by ORIGEN-S for the requested cooling time and extracts the nuclides to be used in the depleted fuel for the burnup credit criticality analysis. Number densities for these nuclides are then written to output files in the SCALE standard composition input format and the KENO V.a mixing table data format for use in CSASN and KENO V.a calculations, respectively. Typically, the term "SNIKR" is used to refer to the three-step sequence of calculations described above.

SNIKR extracts concentrations for the set of nuclides specified by the user. The set of nuclides selected for the reactor critical benchmark calculations consists of the 48 nuclides listed in Table 2. These nuclides are a subset of those in Table 1, with the exception of ${ }^{103} \mathrm{Ru},{ }^{135} \mathrm{I},{ }^{148} \mathrm{Nd}$, and ${ }^{149} \mathrm{Pm}$. The cross sections of these four nuclides are small enough or change slowly enough with burnup that omitting them from the cross-section update in SAS2H has a negligible effect and are therefore not needed in the SAS2H calculation. In addition to the 25 nuclides selected for use in burnup credit analysis in ref. 4 , the list in Table 2 includes the other nuclides included in an earlier burnup credit feasibility study, ${ }^{1}$ together with nuclides modeled explicitly in the burnup credit work of refs. 10 and 13.

\subsection{CROSS-SECTION PROCESSING BY CROSS-SECTION SET}

The CSASN ${ }^{6}$ sequence of the SCALE system is used to compute problem-dependent fuel pin cross sections based on the isotopic content and geometry of a lattice fuel cell. Based on a 1-D fuel pin model, CSASN invokes BONAMT-S ${ }^{14}$ to perform resonance-shielding calculations using Bondarenko factors, followed by NITAWL-II ${ }^{15}$ calculations to perform resolved resonance range cross-section processing using the Nordheim Integral Treatment.

CSASN cross-section processing is applied only to cross-section-set-averaged nuclide concentrations. As discussed earlier in Sect. 2.1, effective cross sections are not strongly coupled to burnup; hence it is sufficient to compute cross sections for the average burnup of a cross-section set, provided the range of burnups in the cross-section set is not too large (less than 2 GWd/MTU). Nuclide concentrations for use in the CSASN calculation are provided in the SCALE standard composition format in the output from the SNIKR cross-section set calculations.

Because fission-product nuclides represent only a small fraction of the total number density of the fuel, fission-product cross sections are relatively insensitive to the varying isotopic content and need only be calculated for one cross-section set. This insensitivity is also true of many fuel activation products and minor actinides; however, cross sections for seven actinides are known to have a more significant burnup dependence. These isotopes, referred to as the "seven burnup-dependent actinides," are ${ }^{234} \mathrm{U},{ }^{235} \mathrm{U},{ }^{236} \mathrm{U},{ }^{238} \mathrm{U},{ }^{239} \mathrm{Pu},{ }^{240} \mathrm{Pu}$, and ${ }^{241} \mathrm{Pu}$. CSASN cross-section set fuel pin models include the appropriate SNIKR-computed concentrations for each of these isotopes; the remaining nuclides are included only in the highest burnup cross-section set. The highest burnup is 
Table 2. Set of fuel nuclides used in KENO V.a calculations

\begin{tabular}{ccc}
\hline${ }^{234} \mathrm{U}^{a}$ & ${ }^{83} \mathrm{Kr}^{d}$ & ${ }^{141} \mathrm{Pr}^{b}$ \\
${ }^{235} \mathrm{U}^{a}$ & ${ }^{93} \mathrm{Zr}^{b}$ & ${ }^{143} \mathrm{Nd}^{a}$ \\
${ }^{236} \mathrm{U}^{a}$ & ${ }^{95} \mathrm{Mo}^{a}$ & ${ }^{145} \mathrm{Nd}^{a}$ \\
${ }^{238} \mathrm{U}^{a}$ & ${ }^{99} \mathrm{Tc}^{a}$ & ${ }^{147} \mathrm{Nd}^{c}$ \\
${ }^{237} \mathrm{~Np}^{b}$ & ${ }^{101} \mathrm{Ru}^{b}$ & ${ }^{148} \mathrm{Nd}^{c}$ \\
${ }^{238} \mathrm{Pu}^{a}$ & ${ }^{103} \mathrm{Ru}^{c}$ & ${ }^{147} \mathrm{Pm}^{b}$ \\
${ }^{239} \mathrm{Pu}^{a}$ & ${ }^{103} \mathrm{Rh}^{a}$ & ${ }^{148} \mathrm{Pm}^{c}$ \\
${ }^{241} \mathrm{Pu}^{a}$ & ${ }^{105} \mathrm{Rh}^{c}$ & ${ }^{149} \mathrm{Pm}^{c}$ \\
${ }^{242} \mathrm{Pu}^{a}$ & ${ }^{105} \mathrm{Pd}^{b}$ & ${ }^{147} \mathrm{Sm}^{a}$ \\
${ }^{241} \mathrm{Am}^{a}$ & ${ }^{108} \mathrm{Pd}^{b}$ & ${ }^{149} \mathrm{Sm}^{a}$ \\
${ }^{243} \mathrm{Am}^{b}$ & ${ }^{109} \mathrm{Ag}^{b}$ & ${ }^{150} \mathrm{Sm}^{a}$ \\
${ }^{244} \mathrm{Cm}^{b}$ & ${ }^{135} \mathrm{I}^{c}$ & ${ }^{151} \mathrm{Sm}^{a}$ \\
$\mathrm{O}^{a}$ & ${ }^{131} \mathrm{Xe}^{d}$ & ${ }^{152} \mathrm{Sm}^{a}$ \\
& ${ }^{135} \mathrm{Xe}^{c}$ & ${ }^{153} \mathrm{Eu}^{a}$ \\
& ${ }^{133} \mathrm{Cs}^{a}$ & ${ }^{154} \mathrm{Eu}^{b}$ \\
& ${ }^{134} \mathrm{Cs}^{d}$ & ${ }^{155} \mathrm{Eu}^{b}$ \\
& ${ }^{135} \mathrm{Cs}^{a}$ & ${ }^{155} \mathrm{Gd}^{a}$ \\
\hline
\end{tabular}

${ }^{a}$ The 25 nuclides to be used in burnup credit analysis (ref. 4).

${ }^{b}$ Additional burnup credit nuclides from ref. 1 .

'Additional reactor physics nuclides from Virginia Power's

PDQ calculations (ref. 10).

¿Additional reactor physics nuclides from Yankee Atomic's

CASMO-3/SIMULATE-3 calculations (ref. 13).

chosen because it will result in the lowest resonance absorption, and therefore results in a higher and more conservative $k_{\text {eff }}$, however, the effect is extremely small $(<0.1 \% \Delta \mathrm{k} / \mathrm{k})$.

Once cross sections are computed for each cross-section set, the SCALE utility module WAX ${ }^{16}$ is used to combine all CSASN cross-section set working libraries into a single working library for subsequent use by KENO V.a. All cross sections from the highest burnup cross-section set (containing all fission and activation isotopes) are copied into the combined library. For each of the remaining cross-section-set libraries, only the seven burnup-dependent actinides are copied. In addition, for each of the seven burnup-dependent actinides in each cross-section set, the cross-section ID number is modified by prefixing the cross-section set number to the cross-section ID so that the KENO V.a core model can reference the appropriate cross section for each cross-section set. The cross sections with modified ID numbers are then copied into the combined library.

\subsection{PREPARATION OF THE KENO V.a CORE MODEL}

The geometry of the core model is based on the technical specifications of the core geometry; the detailed mechanics of the geometry model are discussed later. Using one-eighth-core symmetry, 
it is possible to build a full-core model using a relatively small number of unique assemblies. For each assembly type, nuclide concentrations are obtained from assembly-specific SNIKR output in KENO V.a mixing table format; thus there are unique mixture data for each assembly type in the model. Within each set of mixing table data, the nuclide ID number of each of the seven burnupdependent actinides is prefixed by the cross-section-set number that represents that assembly (this can be done automatically by SNIKR), so that the effective cross sections computed for the corresponding cross-section set are utilized. These cross sections are located in the working library prepared as described in the previous subsection. 


\section{PREPARATION OF THE NORTH ANNA 1 CYCLE 5 CORE MODEL}

The previous section has given an overview of the technical procedure used in setting up the North Anna 1 Cycle 5 reactor critical calculations to provide a broad overview of the entire process before concentrating on the details. This section describes the North Anna 1 Cycle 5 core, then details the specifics of each step used to set up a model for this core based on the geometry, contents, and operating history of the core. Rather than follow the five steps used previously to outline the procedure, this section will describe each distinct aspect of the process, as illustrated by the individual boxes in Fig. 1.

Discussion of the KENO V.a criticality calculation results will be provided in Sect. 4 of this report.

\subsection{CORE DESCRIPTION}

The North Anna 1 Cycle 5 core consisted of 157 Westinghouse fuel assemblies, each comprised of a $17 \times 17$ lattice containing 264 fuel rods, 24 control rod guide tubes, and 1 instrument tube. The core configuration is shown in Fig. 3 where each square represents an assembly position. At-power reactivity control was maintained using four control banks and two shutdown banks of fulllength Ag-In-Cd control rod clusters, 68 BPR clusters containing a total of 912 fresh and 192 depleted BPRs, and soluble boron. Within each assembly, the lattice positions of guide tubes and/or BPRs are located as illustrated in Fig. 4. The loading of the BPR clusters in Cycle 5 is shown in Fig. 5. Design data were obtained from ref. 17.

The critical condition modeled in this report is based on HZP startup testing for BOC-5. The critical boron concentration was $1836 \mathrm{ppm}$. All core components were assumed to be at a constant temperature of $559 \mathrm{~K}\left(547^{\circ} \mathrm{F}\right)$ based on nominal HZP conditions. All control rods were fully withdrawn to the all-rods-out (ARO) position. The downtime between Cycles 4 and 5 was 136 days ( 0.372 years).

For Cycle 5, five fuel batches were present in the core. Fuel batch 4 was manufactured with $3.21 \mathrm{wt} \%{ }^{235} \mathrm{U}$. The batch 4 fuel assemblies loaded in Cycle 5 were loaded in Cycles 2 and 3 but were discharged prior to Cycle 4. Batch 5 was manufactured with $3.41 \mathrm{wt} \%{ }^{235} \mathrm{U}$ and was loaded in Cycles 3 and 4. Batch 6 was manufactured with 3.59 wt $\%{ }^{235} \mathrm{U}$ and was initially loaded in Cycle 4. Two fresh fuel batches, $7\left(3.60 \mathrm{wt} \%{ }^{235} \mathrm{U}\right)$ and $\mathrm{N} 2 / 5\left(3.59 \mathrm{wt} \%{ }^{235} \mathrm{U}\right)$ were loaded in Cycle 5. The batch N2/5 fuel assemblies were originally manufactured for North Anna Unit 2 but were transferred to Unit 1 when damaged fuel assemblies caused an emergency redesign for North Anna Unit 1 Cycle 5. A full-core loading map and assembly burnup data for Cycle 2 are included in Appendix A. Table 3 provides a physical description of the significant aspects of the fuel design for all assemblies.

To simplify and reduce the volume of input in the KENO V.a model, eighth-core symmetry was assumed in the isotopic input. This assumption reduces the number of fuel assemblies with unique enrichment and burnup specifications to 26 (Fig. 6). The loading pattern for North Anna Unit 1 Cycle 5 (Fig. A.1) was approximately eighth-core symmetric. One batch $\mathrm{N} 2 / 5$ assembly $\left(3.59 \mathrm{wt} \%{ }^{235} \mathrm{U}\right)$ was loaded with three batch 7 assemblies $\left(3.60 \mathrm{wt} \%{ }^{235} \mathrm{U}\right)$ as a symmetric grouping. The assembly burnups were averaged from Table A.1 based on the eighth-core symmetry shown in Fig. 6. Assembly burnups listed throughout the remainder of this report are eighth-core average values. 
(B) Burnable Poison Rod Cluster

Control Rod Cluster

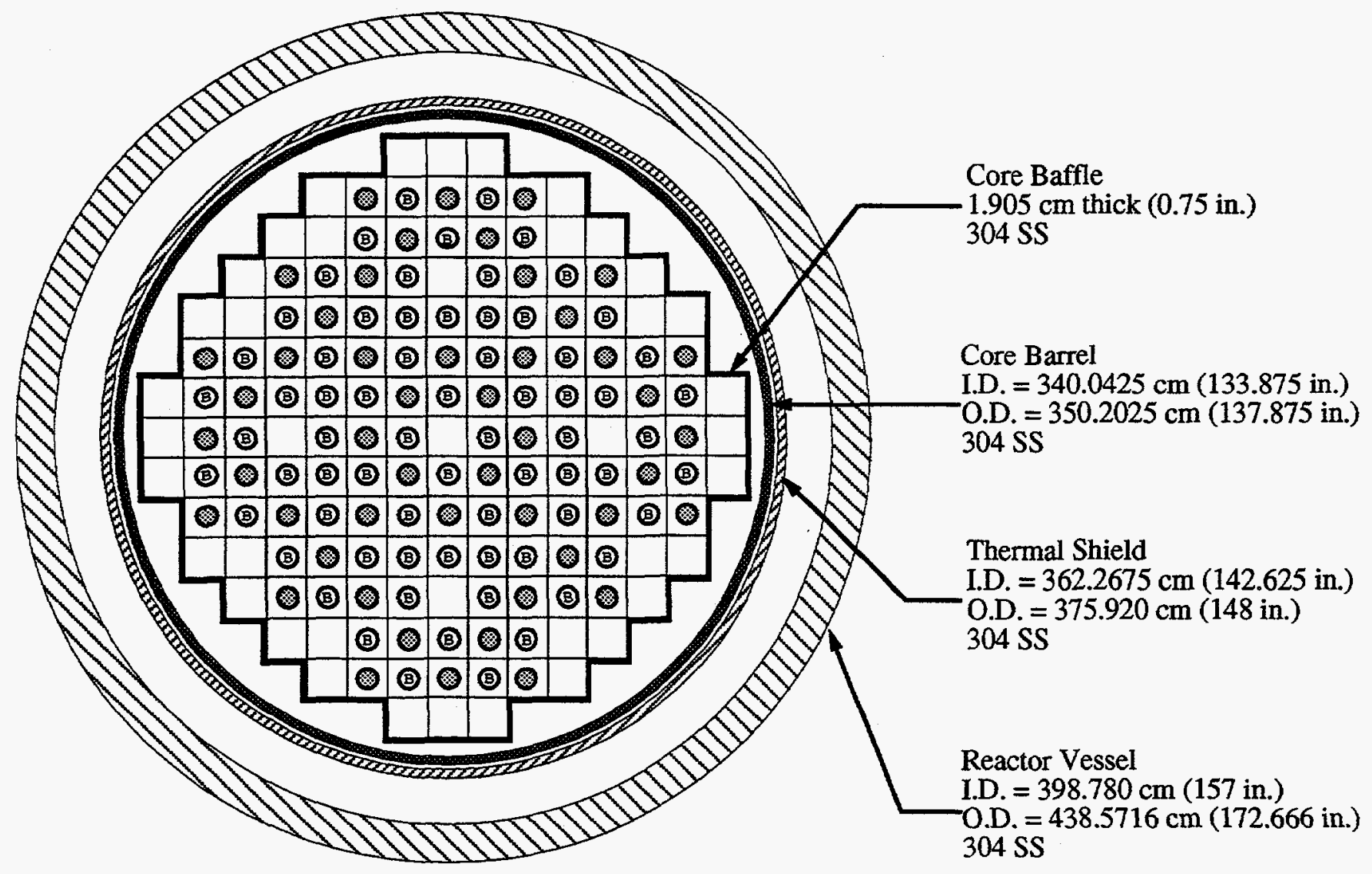

Fig. 3. North Anna Unit 1 Cycle 5 core configuration. 
$\bigotimes$ BURNABLE POISON (BP) ROD

$\square$ GUIDE TUBE

Q INSTRUMENT TUBE

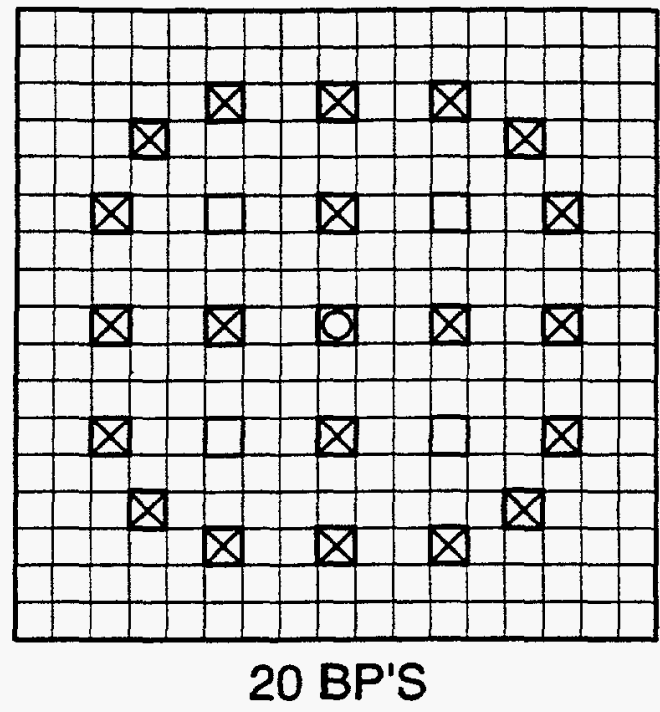

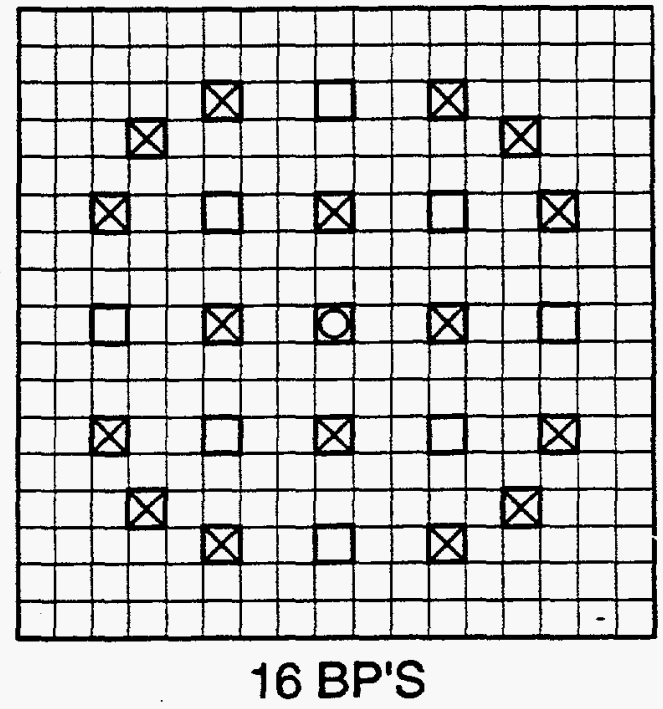

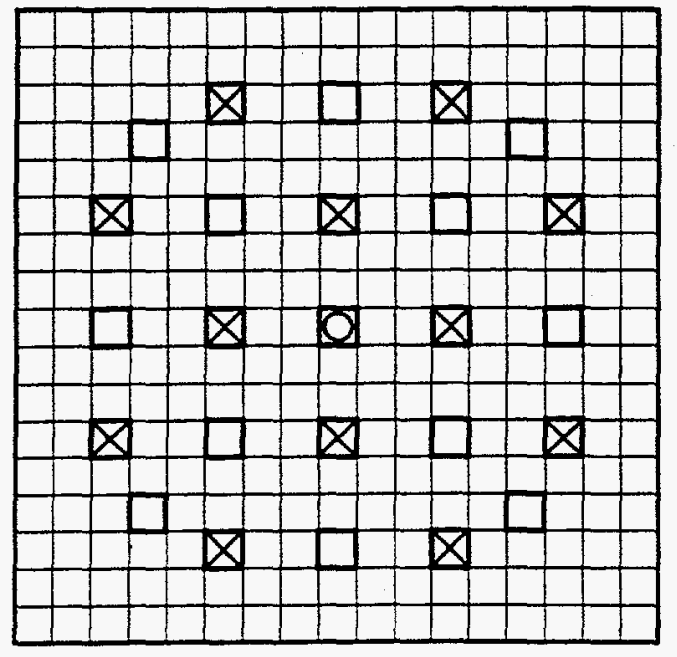

12 BP'S

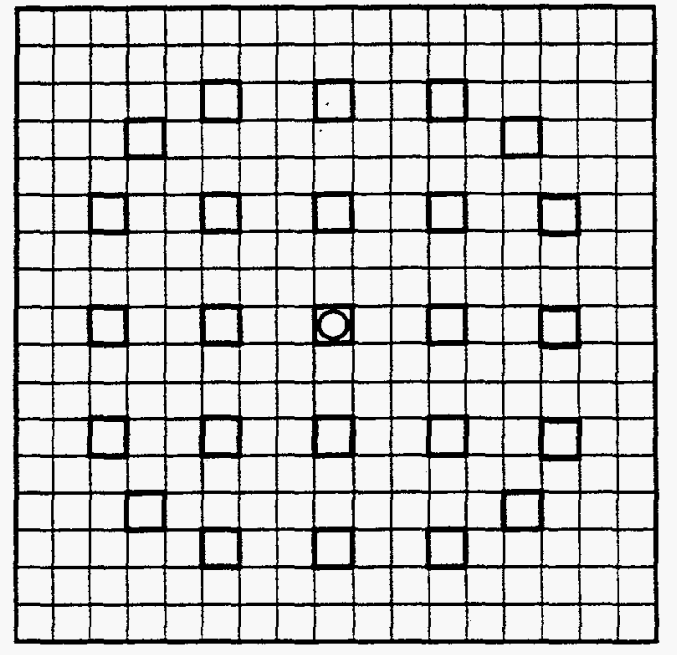

NO BP'S

Fig. 4. Fuel assembly lattice arrangements in North Anna Unit 1 Cycle 5. 
$\begin{array}{llllllllllllllll}\text { R } & \text { P } & \text { N } & \text { M } & \text { L } & \text { K } & \text { J } & \text { H } & \text { G } & \text { F } & \text { E } & \text { D } & \text { C } & \text { B } & \text { A }\end{array}$

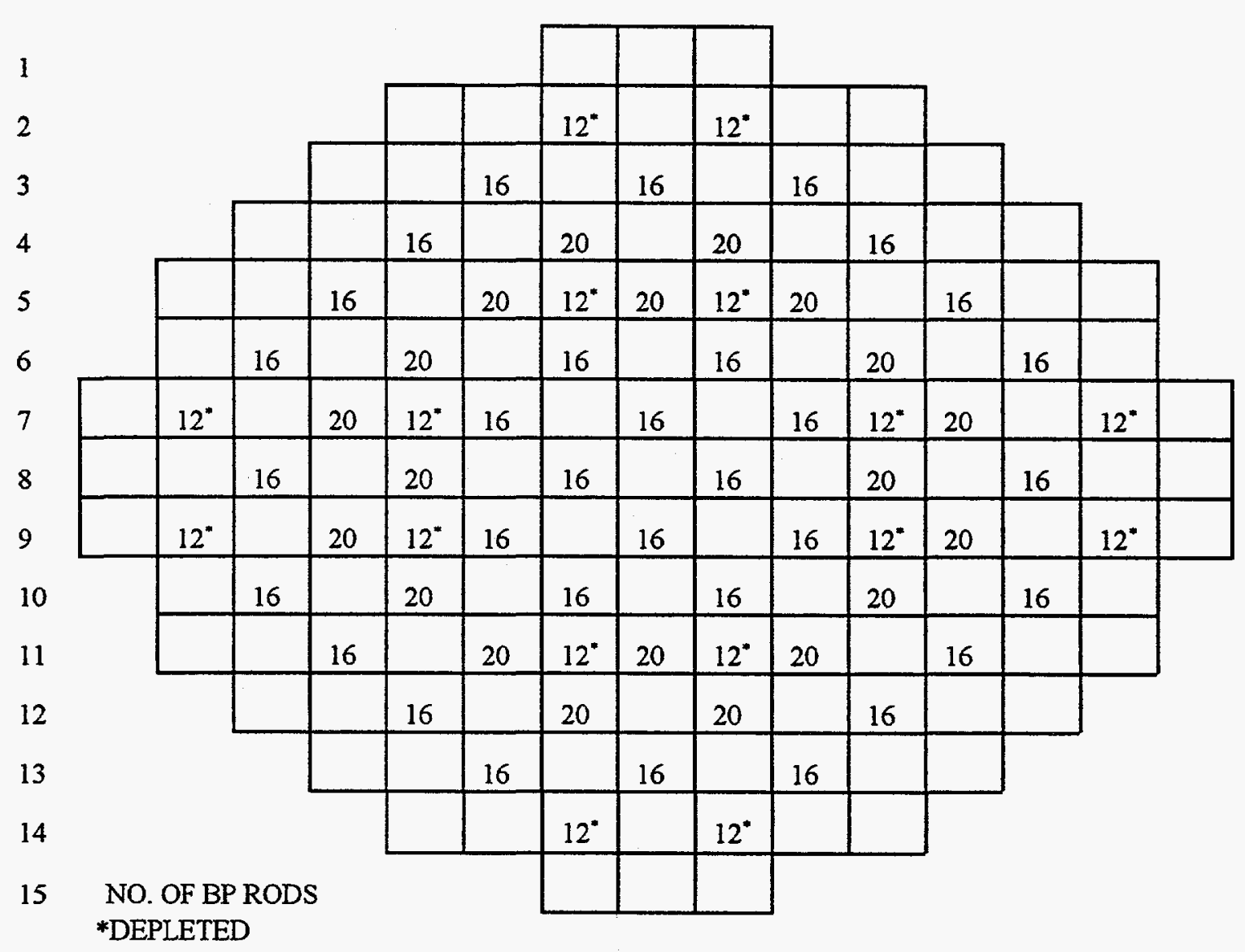

1104 BP RODS

52 FRESH BP CLUSTERS

16 DEPLETED BP CLUSTERS

Fig. 5. North Anna Unit 1 Cycle 5 burnable poison loading configuration. 
Table 3. North Anna PWR Unit 1 assembly design description

\begin{tabular}{|c|c|}
\hline Parameter & Data \\
\hline \multicolumn{2}{|l|}{ Assembly general data } \\
\hline Number of assemblies & 157 \\
\hline Designer & Westinghouse \\
\hline Lattice & $17 \times 17$ \\
\hline Coolant pressure, psia & 2250 \\
\hline Water temperature, $\mathrm{K}\left({ }^{\circ} \mathrm{F}\right)$ & $583.4(590.8)^{a}$ \\
\hline Water density, $\mathrm{g} / \mathrm{cm}^{3}$ & $0.7041^{a, b}$ \\
\hline Number of fuel rods & 264 \\
\hline Number of guide tubes & 24 \\
\hline Number of instrument tubes & 1 \\
\hline Lattice pitch, cm (in.) & $21.50364(8.466)$ \\
\hline \multicolumn{2}{|l|}{ Fuel rod data } \\
\hline Type fuel pellet & $\mathrm{UO}_{2}$ \\
\hline Rod pitch, cm (in.) & $1.25984(0.496)$ \\
\hline Rod OD, cm (in.) & $0.94966(0.374)$ \\
\hline Rod ID, cm (in.) & $0.83566(0.329)$ \\
\hline Pellet diameter, $\mathrm{cm}$ (in.) & $0.81915(0.3225)$ \\
\hline Active fuel length, $\mathrm{cm}$ (in.) & $365.8(144)$ \\
\hline Effective fuel temperature, $\mathrm{K}\left({ }^{\circ} \mathrm{F}\right)$ & $901(1162)^{\circ}$ \\
\hline Clad temperature, $\mathrm{K}\left({ }^{\circ} \mathrm{F}\right)$ & $629(670)^{c}$ \\
\hline Clad material & Zircaloy-4 \\
\hline \multicolumn{2}{|l|}{ Guide tube data } \\
\hline $\mathrm{D}$, in. & $1.143(0.45)$ \\
\hline$O D$, in. & $1.22428(0.482)$ \\
\hline Tube material & Zircaloy-4 \\
\hline \multicolumn{2}{|l|}{${ }^{a}$ Average HFP value. } \\
\hline
\end{tabular}


ORNL-DWG 93M-10021

$\begin{array}{lllllllllllllll}R & P & N & M & L & K & J & H & G & F & E & D & C & B & A\end{array}$

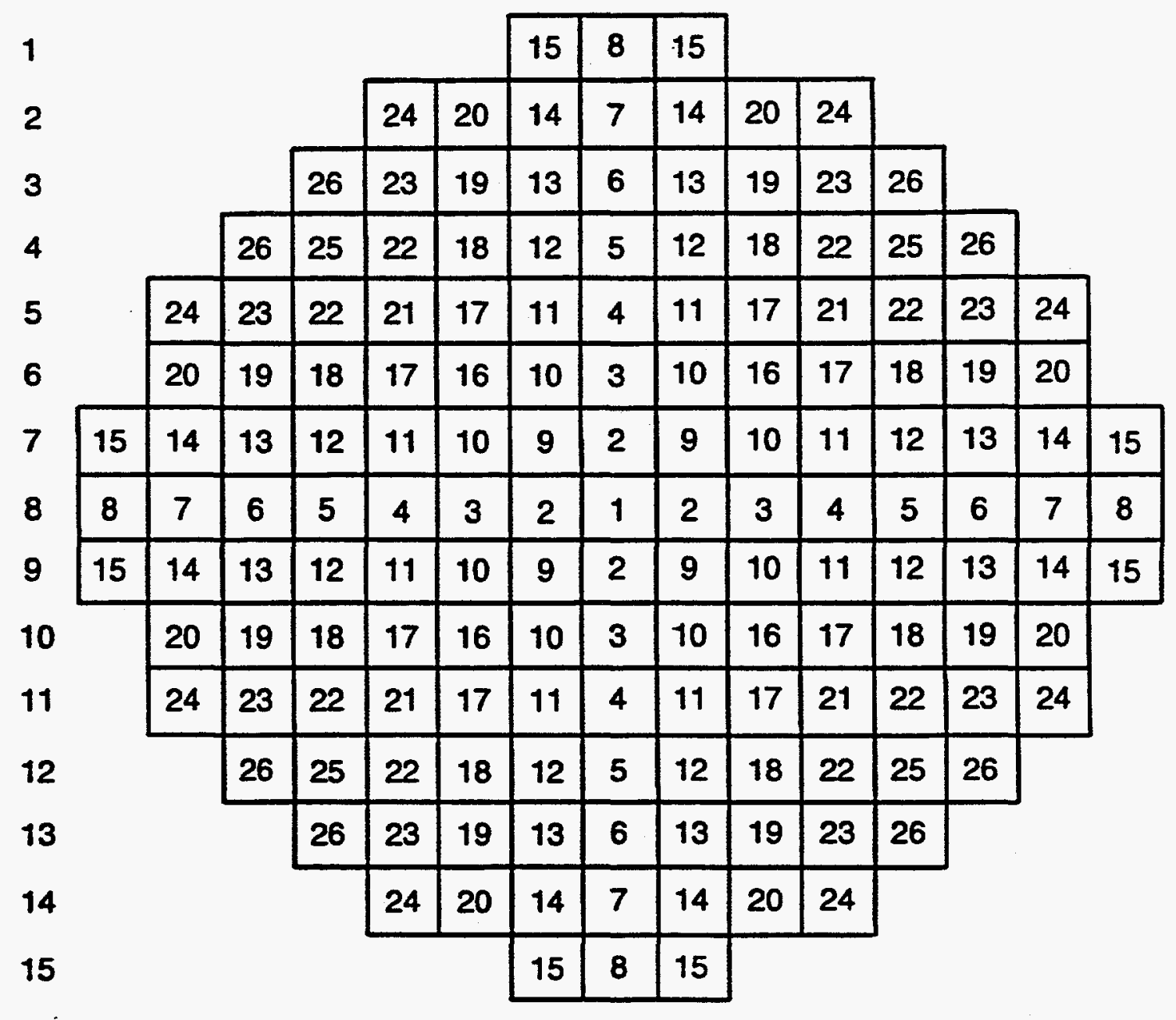

Fig. 6. North Anna Unit 1 eighth-core symmetric configuration. 


\subsection{SAS2H FUEL GROUPS}

Assemblies of a given fuel batch are generally relocated within the core between cycles, resulting in a more evenly distributed burnup among assemblies. Because all fuel assemblies in a batch are loaded in the core during the same operating cycles, each assembly in a batch experiences the same operating (uptime/downtime) history. Thus a starting point for the process of grouping similar-content assemblies is to begin with fuel batches. As indicated in Fig. 1, assembly group information was used in preparation of SAS2H input for depletion calculations. For BOC-5, the North Anna 1 core was comprised of five fuel batches. Because BPR clusters were loaded in certain assemblies in batches 6 and 7, additional subdivision of these batches was necessary. Each of these batches was divided into two fuel groups. Each depleted fuel group was modeled as a single unit in a SAS2H depletion calculation over the range of burnups represented by the assemblies in the group. Table 4 provides relevant information about each fuel group.

Because the only critical configuration to be modeled is at BOC-5, it was not necessary to model fuel depletion in Cycle 5. Based on the reasons presented in Sect. 2.2, it was not considered necessary to model BPRs in previous cycles to generate the depleted fuel isotopics. Thus both Batch 6 fuel groups, $6 \mathrm{~B}$ and $\mathrm{N}$, were modeled with a single SAS2H depletion using the group $\mathrm{N}$ (no BP) model. This modeling simplification was done to remain consistent with the simplifying assumptions in the general methodology. However, 16 depleted BP clusters of 12 BPRs, each from Batch 6 fuel in Cycle 4, were loaded in Cycle 5. Although the group 6N SAS2H depletion was used for the fuel isotopics, it was necessary to perform a SAS2H depletion using the group 6B (12 BP) model to generate the depleted BPR isotopics only.

The initial uranium content of each group was determined from the initial ${ }^{235} \mathrm{U}$ enrichment of the associated fuel batch. The following empirical relationship was used to determine relative isotopic content: ${ }^{19}$

$$
\begin{aligned}
& w_{234}=0.007731\left(w_{235}\right)^{1.0837}, \\
& w_{236}=0.0046 w_{235}, \\
& w_{238}=100-w_{234}-w_{235}-w_{236},
\end{aligned}
$$

where $w$ is the weight percentage of the given uranium isotope. Using this formulation, the fresh fuel isotopics for all enrichments were computed. The results are given in Table 5.

In addition to the heavy-metal fuel material, light elements are also present in the fuel assembly in the fuel clad and grid. Elements whose masses are typically found to be in excess of 0.5 $\mathrm{g} / \mathrm{kgU}$, plus manganese and cobalt, are shown in Table 6, along with their estimated masses. These masses are required by SAS2H. They are not used in the neutronics model, but are applied in determining the $(n, \gamma)$ fraction of energy per fission.

Each SAS2H calculation also requires specification of the temperature of each material for use in cross-section Doppler broadening corrections. However, since material and, therefore, thermal properties change with exposure, and because an assembly's peak temperature is a function of its linear heat rate, the average temperature in the fuel (and to a lesser extent the average clad temperature) will change with burnup and location. The only thermal data available were average fuel, clad, and moderator temperatures as given in Table 3 . 
Table 4. Fuel group data for BOC-5

\begin{tabular}{|c|c|c|c|c|c|c|c|c|}
\hline $\begin{array}{c}\text { SAS2H } \\
\text { fuel } \\
\text { group } \\
\end{array}$ & $\begin{array}{c}\text { North Anna-1 } \\
\text { fuel } \\
\text { batch }\end{array}$ & $\begin{array}{c}\begin{array}{c}\text { No. } \\
\text { of } \\
\text { assemblies }\end{array} \\
\end{array}$ & $\begin{array}{l}\text { Contain } \\
\text { BPRs in } \\
\text { Cycle } 5 \\
\end{array}$ & $\begin{array}{l}\text { Cycles } \\
\text { in-core }\end{array}$ & $\begin{array}{c}\text { Av. B/U } \\
\text { (MWd/MTU) }\end{array}$ & $\begin{array}{c}\text { Min. B/U } \\
\text { (MWd/MTU) }\end{array}$ & $\begin{array}{c}\text { Max. B/U } \\
\text { (MWd/MTU) }\end{array}$ & $\begin{array}{l}\text { Enrichment } \\
\text { (wt \%) }\end{array}$ \\
\hline 4 & 4 & 12 & No & $2,3,5$ & 24,986 & 21,493 & 26,732 & 3.21 \\
\hline 5 & 5 & 20 & No & $3,4,5$ & 29,255 & 20,951 & 32,048 & 3.41 \\
\hline $6 \mathrm{~B}$ & 6 & 8 & Depleted & 4,5 & 14,081 & 14,081 & 14,081 & 3.59 \\
\hline $6 \mathrm{~N}$ & 6 & 49 & No & 4,5 & 15,101 & 9,801 & 17,390 & 3.59 \\
\hline $7 \mathrm{~B}$ & 7 & 52 & Fresh & 5 & 0 & 0 & 0 & 3.60 \\
\hline $7 \mathrm{~N}$ & 7 & 8 & No & 5 & 0 & 0 & 0 & 3.60 \\
\hline $\mathrm{N} 2 / 5$ & $\mathrm{~N} 2 / 5$ & 8 & Depleted & 5 & 0 & 0 & 0 & 3.59 \\
\hline
\end{tabular}

Table 5. Initial uranium isotopic content of fresh fuel

\begin{tabular}{|c|c|c|c|c|c|}
\hline \multirow{3}{*}{$\begin{array}{l}\text { Fuel } \\
\text { batch }\end{array}$} & \multirow{3}{*}{$\begin{array}{c}\% \\
\text { Theoretical } \\
\text { density }\end{array}$} & \multirow{2}{*}{\multicolumn{4}{|c|}{ Initial U isotopes, wt \% }} \\
\hline & & & & & \\
\hline & & ${ }^{234} \mathrm{U}$ & ${ }^{235} \mathrm{U}$ & ${ }^{236} \mathrm{U}$ & ${ }^{238} \mathrm{U}$ \\
\hline 4 & 94.55 & 0.027 & 3.21 & 0.015 & 96.748 \\
\hline 5 & 94.58 & 0.029 & 3.41 & 0.016 & 96.545 \\
\hline 6 & 94.58 & 0.031 & 3.59 & 0.017 & 96.363 \\
\hline 7 & 94.89 & 0.031 & 3.60 & 0.017 & 96.352 \\
\hline $\mathrm{N} 2 / 5$ & 94.88 & 0.031 & 3.59 & 0.017 & 96.352 \\
\hline
\end{tabular}

Table 6. Light-element masses used in SAS2H calculations

\begin{tabular}{cc} 
Element & Weight, g/kgU \\
\hline $\mathrm{O}$ & 135.0 \\
$\mathrm{Cr}$ & 5.9 \\
$\mathrm{Mn}$ & 0.33 \\
$\mathrm{Fe}$ & 12.9 \\
$\mathrm{Co}$ & 0.075 \\
$\mathrm{Ni}$ & 9.9 \\
$\mathrm{Zr}$ & 221.0 \\
$\mathrm{Nb}$ & 0.71 \\
$\mathrm{Sn}$ & 3.6 \\
\hline
\end{tabular}




\subsubsection{SAS2H Fuel Cell Without BPRs}

The SAS2H fuel cell model input for the three fuel groups without BPR clusters, groups 4, 5 , and $₫ \mathrm{~N}$, was relatively simple. Requirements included the dimensions of the fuel rod, clad, controlrod guide tube, and lattice pitch and the number of lattice positions in each fuel assembly not occupied by fuel rods (i.e., control rod guide tubes or instrumentation tubes). From this basic information included in Table 3, SAS2H constructed a 1-D effective assembly model, consisting of a guide tube surrounded by a fuel/moderator region with a volume proportional to the fuel/guide tube volume ratio in the assembly. Cross sections for the fuel region are obtained from a pin cell calculation. More details of this default SAS2H assembly model can be found in ref. 5 .

\subsubsection{SAS2H Fuel Cell With BPRs}

For fuel group 6B with BPR clusters, an effective fuel cell was derived to incorporate the BPR cell together with the guide tube cell in SAS2H. In the effective cell, the densities of the isotopes or elements remained unchanged from their actual densities, but rod diameters of the glass and stainless steel in the BPRs were reduced to account for their absence in the guide tube positions. The method of deriving the effective cell was such that the various material total masses were conserved.

The composition of the borosilicate glass as modeled is listed in Table 7. The value for $\mathrm{B}_{2} \mathrm{O}_{3}$ was obtained from Vol. 2 of this report. ${ }^{18}$ All other data for typical borosilicate glass were obtained from ref. 20 . These data and atomic weights of the elements and isotopic abundance values, ${ }^{21}$ were applied in deriving the atomic densities of the borosilicate glass in Table 8. The glass density, $2.23 \mathrm{~g} / \mathrm{cm}^{3}$, was also obtained from ref. 20 .

The number of BPRs was 12, and the number of guide tubes (including the instrumentation tube) was 13 per assembly-a total of 25 nonfuel locations per assembly. Applying these totals and the dimensions of the BPRs, guide tubes, and lattice pitch, a set of effective unit cell dimensions was computed. Note that in the analyses previously performed for Sequoyah and Surry in Vols. 2 and 3 of this report, the instrumentation tube was inadvertently omitted from the fuel cell calculations. The radius bounding each material was calculated from the outer to inner zone boundary for each average material volume. For example, the water moderator average volume, $\bar{V}_{w}$, is

$$
\bar{V}_{w}=(12)\left(V_{T}-V_{G T}-V_{B P}\right) / 25+(13)\left(V_{T}-V_{G T}\right) / 25 \text {, }
$$

where

$$
\begin{aligned}
V_{T} & =\text { total cell volume }=(\text { pitch })^{2} \times(\text { length }) \\
V_{G T} & =\text { guide tube volume }(\text { same as outer tube in BPR cell }) \\
V_{B P} & =\mathrm{BP} \text { rod total volume. }
\end{aligned}
$$

Then the inner radius of the water, or the effective radius of the BP rod, is

$$
R_{B P}=\sqrt{\left(V_{T}-\bar{V}_{w}-V_{G T}\right) /(\pi L)},
$$


Table 7. Borosilicate glass composition in BPR assemblies

\begin{tabular}{lc}
\hline Compound & Weight fraction \\
\hline $\mathrm{SiO}_{2}$ & 0.805 \\
$\mathrm{~B}_{2} \mathrm{O}_{3}$ & 0.125 \\
$\mathrm{Na}_{2} \mathrm{O}$ & 0.038 \\
$\mathrm{~K}_{2} \mathrm{O}$ & 0.004 \\
$\mathrm{Al}_{2} \mathrm{O}_{3}$ & 0.022 \\
\hline
\end{tabular}

Table 8. Borosilicate glass input atom densities ${ }^{a}$

\begin{tabular}{|c|c|c|c|}
\hline Element & Isotope & Weight fraction & $\begin{array}{l}\text { Density, } \\
\text { atoms } /(\mathrm{barn} \cdot \mathrm{cm})\end{array}$ \\
\hline 0 & & 0.5358 & 0.04497 \\
\hline $\mathrm{Na}$ & & 0.0282 & 0.00165 \\
\hline $\mathrm{Al}$ & & 0.0116 & 0.00058 \\
\hline $\mathrm{Si}$ & & 0.3763 & 0.01799 \\
\hline $\mathrm{K}$ & & 0.0033 & 0.00011 \\
\hline B & & 0.03882 & \\
\hline & ${ }^{10} \mathrm{~B}$ & & $9.595 \mathrm{E}-4^{b}$ \\
\hline & ${ }^{11} \mathrm{~B}$ & & $3.863 E-3$ \\
\hline Total & & 0.99402 & \\
\hline
\end{tabular}

where $L$ is the active fuel length used in computing the volumes. The guide tube dimensions remain the same because they are identical in both types of cells. Each average volume, $V_{\text {ave }}$, within the effective BP rod is calculated from the corresponding actual BP rod dimensions (and the number of BPRs and guide tubes):

$$
V_{\text {ave }}=(12 \pi L)\left(B^{2}-A^{2}\right) / 25 \text {, }
$$


where

$A=$ the material's inner radius in an actual BP rod,

$B=$ the same material zone's outer radius.

Using the prior calculation of the effective outer radius, $B_{e}$, the effective inner radius, $A_{e}$, is

$$
A_{e}=\sqrt{B_{e}^{2}-V_{a v e} /(\pi L)}
$$

Equations (1) and (2) are used repeatedly for each material zone for the entire effective cell determination. Applying the above procedure, the effective cell mockup dimensions were computed as listed in Table 9.

The densities listed in the table were used only in computing material mass for verification of data. The total material masses of the actual BP rods plus that of the guide tubes were compared with the effective cell total masses. The data were used to verify the cell dimensions. In all cases identical weights were computed for the same materials, verifying that the effective cells conserve mass.

\subsection{SIMILAR-BURNUP SUBGROUPING FOR CROSS-SECTION SETS}

Although the assemblies of a given fuel group are identical in terms of initial composition, time in core, and operating history, there may be a relatively broad range of burnups within a fuel group. Even though effective cross sections are felt to be insensitive to minor variations in burnups, it is necessary to set a maximum range of burnups for which an average burnup is an acceptable approximation in determining cross sections. As discussed earlier, a range of no more than $2 \mathrm{GWd} / \mathrm{MTU}$ has been found to be acceptable; this value was used in subdividing fuel groups into similar-burnup cross-section sets. As shown in Fig. 1, cross-section-set information is provided to SNIKR for subsequent use in setting up CSASN calculations. CSASN is used to compute effective cross sections for each cross-section set.

To determine cross-section sets for each fuel group, the fuel assembly burnups in each group were sorted and divided into subgroups where the minimum to maximum burnup range was no larger than $2 \mathrm{GWd}$ /MTU. Eighth-core-averaged assembly burnups are given in Table 10, along with fuel batch, SAS2H fuel group, and cross-section set information. The cross-section-set groupings are shown in Table 11. Table 12 shows the cross-section sets, with the actual burnup ranges for assemblies within each cross-section set, along with the mean average burnup of all assemblies in each cross-section set.

\subsection{SAS2H DEPLETION CALCULATIONS}

SAS2H depletion calculations were required for fuel groups 4,5 , and 6 only, since the other groups consisted of fresh fuel at the time of startup. In the standard composition section of the SAS2H input for each fuel group, the initial uranium isotopic contents for the fuel were as given in Table 5. Although not initially present in the fuel, the additional 44 nuclides from Table 1 were 
Table 9. Effective fuel cell with 12 BPRs

\begin{tabular}{|c|c|c|c|c|}
\hline Zone & Material & $\begin{array}{l}\text { Density, } \\
\left(\mathrm{g} / \mathrm{cm}^{3}\right)\end{array}$ & $\begin{array}{l}\text { SAS2H } \\
\text { mixture } \\
\text { number }\end{array}$ & $\begin{array}{l}\text { Radius } \\
\text { in cell } \\
(\mathrm{cm})\end{array}$ \\
\hline 1 & Air & $1.22 \mathrm{E}-3^{a}$ & 4 & 0.14826 \\
\hline 2 & SS-304 & 7.92 & 5 & 0.15970 \\
\hline 3 & Air & $1.22 \mathrm{E}-3$ & 4 & 0.16718 \\
\hline 4 & Glass & 2.23 & 6 & 0.29564 \\
\hline 5 & Air & $1.22 \mathrm{E}-3$ & 4 & 0.30268 \\
\hline 6 & SS-304 & 7.92 & 5 & 0.33523 \\
\hline 7 & Mod & 0.7149 & 3 & 0.57150 \\
\hline 8 & $\mathrm{Zr}-4$ & 6.44 & 2 & 0.61214 \\
\hline 9 & Mod & 0.7149 & 3 & 0.71079 \\
\hline 10 & Fuel & - & 500 & 2.41668 \\
\hline
\end{tabular}


Table 10. Fuel assembly data for eighth-core geometry

\begin{tabular}{|c|c|c|c|c|}
\hline $\begin{array}{l}\text { Eighth-core } \\
\text { location }\end{array}$ & $\begin{array}{l}\text { North Anna } \\
\text { fuel } \\
\text { batch }\end{array}$ & $\begin{array}{l}\text { SAS2H } \\
\text { fuel } \\
\text { group }\end{array}$ & $\begin{array}{l}\text { Cross- } \\
\text { section } \\
\text { set }\end{array}$ & $\begin{array}{c}\text { Average } \\
\text { burnup } \\
\text { (MWd/MTU) }\end{array}$ \\
\hline 1 & 6 & $6 \mathrm{~N}$ & 7 & 17105 \\
\hline 2 & 7 & $7 \mathrm{~B}$ & 11 & 0 \\
\hline 3 & 4 & 4 & 1 & 21493 \\
\hline 4 & 7 & $7 \mathrm{~B}$ & 11 & 0 \\
\hline 5 & 6 & $6 \mathrm{~N}$ & 7 & 17322 \\
\hline 6 & 7 & $7 \mathrm{~B}$ & 11 & 0 \\
\hline 7 & 6 & $6 \mathrm{~N}$ & 7 & 17390 \\
\hline 8 & 6 & $6 \mathrm{~N}$ & 5 & 9801 \\
\hline 9 & 5 & 5 & 3 & 20951 \\
\hline 10 & 7 & $7 \mathrm{~B}$ & 11 & 0 \\
\hline 11 & 6 & $6 \mathrm{~N}$ & 8 & 14081 \\
\hline 12 & 7 & $7 \mathrm{~B}$ & 11 & 0 \\
\hline 13 & 6 & $6 \mathrm{~N}$ & 6 & 12890 \\
\hline 14 & $\mathrm{~N} 2 / 5$ & $\mathrm{~N} 2 / 5$ & 9 & 0 \\
\hline 15 & 5 & 5 & 4 & 30615 \\
\hline 16 & 6 & $6 \mathrm{~N}$ & 7 & 17158 \\
\hline 17 & 7 & $7 \mathrm{~B}$ & 11 & 0 \\
\hline 18 & 6 & $6 \mathrm{~N}$ & 7 & 15802 \\
\hline 19 & 7 & $6 \mathrm{~N}$ & 11 & 0 \\
\hline 20 & 6 & $7 \mathrm{~B}$ & 7 & 16831 \\
\hline 21 & 6 & $6 N$ & 7 & 15852 \\
\hline 22 & 7 & $7 \mathrm{~B}$ & 11 & 0 \\
\hline 23 & 7 & $7 \mathrm{~N}$ & 10 & 0 \\
\hline 24 & 5 & 5 & 4 & 32048 \\
\hline 25 & 6 & $6 \mathrm{~N}$ & 6 & 12139 \\
\hline 26 & 4 & 4 & 2 & 26732 \\
\hline
\end{tabular}


Table 11. Cross-section sets for one-eighth-core assemblies

\begin{tabular}{|c|c|c|}
\hline $\begin{array}{c}\text { Cross-section } \\
\text { set No. }\end{array}$ & $\begin{array}{c}\text { Assembly } \\
\text { No. }\end{array}$ & $\begin{array}{c}\text { Burnup } \\
\text { (MWd/MTU) }\end{array}$ \\
\hline 1 & $\begin{array}{l}3 \\
\text { Average }\end{array}$ & $\begin{array}{l}21,493 \\
21,493\end{array}$ \\
\hline 2 & $\begin{array}{l}26 \\
\text { Average }\end{array}$ & $\begin{array}{l}26,732 \\
26,732\end{array}$ \\
\hline 3 & $\begin{array}{l}9 \\
\text { Average }\end{array}$ & $\begin{array}{l}20,951 \\
20,951\end{array}$ \\
\hline 4 & $\begin{array}{l}15 \\
24 \\
\text { Average }\end{array}$ & $\begin{array}{l}30,615 \\
32,048 \\
31,332\end{array}$ \\
\hline 5 & $\begin{array}{l}8 \\
\text { Average }\end{array}$ & $\begin{array}{l}9,801 \\
9,801\end{array}$ \\
\hline 6 & $\begin{array}{l}13 \\
25 \\
\text { Average }\end{array}$ & $\begin{array}{l}12,890 \\
12,139 \\
12,640\end{array}$ \\
\hline 7 & $\begin{array}{l}1 \\
5 \\
7 \\
16 \\
18 \\
20 \\
21 \\
\text { Average }\end{array}$ & $\begin{array}{l}17,105 \\
17,322 \\
17,390 \\
17,158 \\
15,802 \\
16,831 \\
15,852 \\
16,638\end{array}$ \\
\hline 8 & $\begin{array}{l}11 \\
\text { Average }\end{array}$ & $\begin{array}{l}14,081 \\
14,081\end{array}$ \\
\hline 9 & $\begin{array}{l}14 \\
\text { Average }\end{array}$ & $\begin{array}{l}0 \\
0\end{array}$ \\
\hline 10 & $\begin{array}{l}23 \\
\text { Average }\end{array}$ & $\begin{array}{l}0 \\
0\end{array}$ \\
\hline 11 & $\begin{array}{l}2 \\
4 \\
6 \\
10 \\
12 \\
17 \\
19 \\
22 \\
\text { Average }\end{array}$ & $\begin{array}{l}0 \\
0 \\
0 \\
0 \\
0 \\
0 \\
0 \\
0 \\
0\end{array}$ \\
\hline
\end{tabular}


Table 12. Cross-section sets for North Anna Unit 1 Cycle 5 KENO V.a model

\begin{tabular}{rlllccc}
\hline $\begin{array}{c}\text { Cross- } \\
\text { section } \\
\text { set No. }\end{array}$ & $\begin{array}{c}\text { SAS2H } \\
\text { fuel } \\
\text { group }\end{array}$ & Enrichment & $\begin{array}{c}\text { Burnable } \\
\text { poison rods } \\
\text { (BPR) }\end{array}$ & $\begin{array}{c}\text { Average } \\
\text { burnup }\end{array}$ & $\begin{array}{c}\text { Burnup } \\
\text { range }\end{array}$ & $\begin{array}{c}\text { No. of } \\
\text { assemblies }\end{array}$ \\
\hline 1 & 4 & 3.21 & None & 21,493 & 21,493 & 1 \\
2 & 4 & 3.21 & None & 26,732 & 26,732 & 1 \\
3 & 5 & 3.41 & None & 20,951 & 20,951 & 1 \\
4 & 5 & 3.41 & None & 31,332 & $30,615-32,048$ & 2 \\
5 & $6 \mathrm{~N}$ & 3.59 & None & 9,801 & 9,801 & 1 \\
6 & $6 \mathrm{~N}$ & 3.59 & None & 12,640 & $12,139-12,890$ & 2 \\
7 & $6 \mathrm{~N}$ & 3.59 & None & 16,638 & $15,802-17,390$ & 7 \\
8 & $6 \mathrm{~N}$ & 3.59 & Depleted & 14,081 & 14,081 & 1 \\
9 & $\mathrm{~N} 2 / 5$ & 3.59 & Depleted & 0 & 0 & 1 \\
10 & $7 \mathrm{~N}$ & 3.60 & None & 0 & 0 & 1 \\
11 & $7 \mathrm{~B}$ & 3.60 & Fresh & 0 & 0 & 8 \\
\hline
\end{tabular}

included at an atom density of $1 \times 10^{-20}\left({ }^{135} \mathrm{Xe}\right.$ was specified with an initial density on the order of its equilibrium concentration, since it quickly reaches this equilibrium concentration shortly after startup), indicating to SAS2H that cross sections for these isotopes should be updated at the end of each burn cycle as discussed previously in Sect. 2.2. The remainder of the fuel pin cell was described as Zircaloy clad in water, with temperature and geometry data as specified in Table 4 . The active fuel length was divided by the total weight of heavy metal in the assembly. This modification gives results in units of burnup per MTU rather than burnup per assembly. Since SAS2H uses a 1-D assembly cell model, the fuel length is arbitrary and may be used as a conversion factor.

Table 13 gives the power history data used for each SAS2H fuel group. Note that a constant burnup per interval was used for each fuel group; this constant spacing is required by SNIKR when interpolating from SAS2H/ORIGEN output. Shorter burnup intervals were used for the once-burned fuel group 6 to have a sufficient number of data points for SNIKR to interpolate. The number of intervals for each group was chosen so that the maximum assembly burnup was exceeded by at least $20 \%$. The average specific power for each fuel group was calculated by dividing the group average burnup by the total uptimes for all cycles that the fuel was in the core.

A copy of the SAS2H input for fuel group 4 is included in Appendix B. With the exception of the uranium isotopics and the burnup steps, inputs for the other fuel group calculations were identical.

\subsection{BURNUP-DEPENDENT INTERPOLATION OF ISOTOPICS}

The atom density output files from each of the previous SAS2H calculations contain isotopic concentrations for the associated fuel group at each burnup step. Using the appropriate group output, SNIKR1 was used to interpolate between burnup intervals to estimate the isotopic 
Table 13. SAS2H operating history data by fuel group and cycle

\begin{tabular}{|c|c|c|c|c|c|c|c|c|}
\hline $\begin{array}{l}\text { SAS2H } \\
\text { fuel } \\
\text { group }\end{array}$ & $\begin{array}{c}\text { Reactor } \\
\text { cycles }\end{array}$ & $\begin{array}{c}\text { Average } \\
\text { power } \\
(\mathrm{MW} / \mathrm{MTU})\end{array}$ & $\begin{array}{c}\text { Actual } \\
\text { uptime } \\
\text { (d) } \\
\end{array}$ & $\begin{array}{c}\text { Actual } \\
\text { downtime }^{a} \\
\text { (d) }\end{array}$ & $\begin{array}{c}\text { Number of } \\
\text { intervals @ } \\
\text { burnup per } \\
\text { interval } \\
\text { (GWd/MTU) }\end{array}$ & $\begin{array}{c}\text { Modeled } \\
\text { burn time } \\
\text { per interval } \\
\text { (d) }\end{array}$ & $\begin{array}{l}\text { Modeled } \\
\text { downtime } \\
\text { per interval } \\
\text { (d) }\end{array}$ & $\begin{array}{c}\text { Cumulative } \\
\text { burnup } \\
\text { (GWd/MTU) }\end{array}$ \\
\hline 4 & 2,3 & 33.719 & 741 & 103 & 7@5 & 148.28 & 20.61 & 35 \\
\hline 5 & 3,4 & 31.023 & 943 & 185 & 8@5 & 161.17 & 31.62 & 40 \\
\hline 6 & 4 & 27.649 & 541 & 0 & 6@4 & 144.67 & 0 & 24 \\
\hline
\end{tabular}

${ }^{a}$ Does not include downtime after last cycle of operation prior to Cycle 5. 
concentration corresponding to the burnup of each assembly and cross-section set in the North Anna 1 models at BOC-2 and EOC-2. This step was the only one necessary for the EOC-2 case, since it occurred at HFP, equilibrium conditions. For the BOC-2 case, SNIKR1 then used these isotopics (which represented nuclide concentrations at the end of the depletion prior to the critical condition at BOC-2) and prepared an ORIGEN-S decay calculation to obtain the concentration of the isotopes after the appropriate downtime of 0.271 years prior to the BOC-2 startup. After ORIGEN-S was executed, SNIKR3 read the ORIGEN-S output and prepared isotopic concentration tables in both SCALE standard composition input format and KENO mixing table format for the selected set of isotopes listed previously in Table 2.

The SNIKR sequence consists of three codes, described earlier in Sect. 2.3, and requires two files. The first file is a SNIKR input file describing the calculation to be performed for a specific assembly or cross-section set; the second is the SAS2H output file containing the atom density data for the appropriate fuel group. SNIKR calculations are automated in a manner similar to SCALE calculational sequences such that the multistep calling of the individual code packages is transparent to the user. Appendix C lists a user input guide for SNIKR Version 1.0, which was used in these analyses, and FORTRAN listings of SNIKR1 and SNIKR3.

Slightly different approaches are taken between preparation of assembly isotopics and crosssection-set isotopics as the results are used in different applications. The following subsections describe each of the two methods.

\subsubsection{Assembly Isotopics}

In the KENO V.a model of North Anna Unit 1 Cycle 5 eighth-core-averaged assembly isotopics calculations are used to provide the nuclide concentrations for each assembly position. The assembly isotopics are based on the average burnup for the assembly, and all fuel rods within the assembly are assumed to possess the same isotopic composition. Hence material numbers for each fuel rod in a given assembly are identical and correspond to a specific KENO V.a mixture number. This mixture is defined based on results of SNIKR calculations for the burnup of the corresponding assembly. In the North Anna KENO V.a model, mixture numbers 101 through 126 correspond to SNIKR calculations for assemblies 1 through 26, respectively. Eighth-core-averaged assembly burnups are given in Table 10, along with fuel group and cross-section set information.

As discussed earlier in Sect. 2.4, cross-section-set-dependent cross sections are required only for the seven burnup-dependent actinides. SNIKR places the cross-section ID modifier in front of the default cross-section ID for each of these isotopes (e.g., ${ }^{238} \mathrm{U}$, with ID number 92238 , would be described as 292238 for all assemblies located in cross-section set 2). Burnable poison isotopics were similarly generated for each of the two eighth-core fuel assembly locations where depleted BPRs were present in Cycle 5. Sample SNIKR input files are included in Appendix C.

The SNIKR output file consists of three sections: a summary of the input and coarsely formatted ORIGEN-S results, isotopic concentrations in SCALE standard composition input format, and isotopic concentrations in KENO V.a mixing table input format. For each assembly calculation, only the latter was of interest; this section was copied and placed directly into KENO V.a input to describe the isotopic composition for the burnup of a specific assembly. A sample SNIKR output is also listed in Appendix C. 


\subsubsection{Cross-Section Set Isotopics}

Burnup-dependent cross sections were required for the seven burnup-dependent actinides. As was previously mentioned, cross-section set calculations were performed with CSASN to obtain the cross sections for these actinides for each cross-section set based on the average burnup groupings shown in Table 13; these groupings were selected based on the burnup range criterion of $2 \mathrm{GWd} / \mathrm{MTU}$ discussed earlier. SNIKR calculations were required for cross-section sets 1 through 8 . The seven burnup-dependent actinides were needed for each set of burned fuel. In addition, cross-section set 4 also included the other actinides and fission products in the fuel mixture.

The SNIKR output file is the same format as was produced for the assembly calculations; however, the region of output data which was of interest was different. The isotopic concentrations in SCALE standard composition input format were copied to a CSASN input file.

\subsection{GENERATION OF CROSS SECTIONS USING CSASN}

Problem-dependent cross-section libraries were produced using the CSASN sequence of SCALE; the details of this process were described in Sect. 2.4. For each cross-section set, a CSASN input deck containing cross-section-set average isotopics was created. Because the physical geometries of all fuel pins were identical, input specifications differed only in the isotopic compositions specified for each set. All cases were set up to use the SCALE ENDF/B-IV and ENDF/B-V based 27-group 27BURNUPLIB cross-section library. All calculations were LATTICECELL-type, with fuel in a Zircaloy clad, with dimensions as specified in Table 4. A borated-water moderator was specified, with a soluble boron concentration. All components were specified with a temperature of $559 \mathrm{~K}\left(547^{\circ} \mathrm{F}\right)$, corresponding to $\mathrm{HZP}$ conditions. An example input listing is shown in Appendix D.

Isotopic concentrations were obtained from the earlier SNIKR cross-section set calculations. Since only the seven burnup-dependent actinides were required for sets 1 through 3 and 5 through 8 , all other actinides and fission products were deleted from the fuel mixture specifications for these cases. Cross-section sets 9 through 11 , comprised only of fresh fuel were specified using the fresh isotopic compositions given in Table 6 . The microscopic cross-section calculations for cross-section set 4 also included the other actinides and fission products in the fuel mixture, along with mixtures for the moderator and structural materials. Cross-section set 4 was selected for these calculations because its spent fuel isotopics represented the highest average burnup. The input listing for crosssection set 4 is also included in Appendix D. The microscopic cross-section calculations for crosssection sets 8, 9, and 11 included the BPR nuclides. CSASN calculations were then performed, with the resulting microscopic working format cross-section library saved for each cross-section set.

\subsection{COMBINING CROSS-SECTION SET LIBRARIES USING WAX}

The WAX ${ }^{16}$ code was used to combine the individual working format libraries (one per crosssection set) into a single library to be used in the KENO V.a core calculation. For cross-section set 4 , selected to include the fission products and additional actinides, WAX copied all cross sections into the combined library. For the cross-section sets selected for the BPR cross sections, WAX copied 
those cross sections in addition to the seven burnup-dependent actinides. For the remaining crosssection sets, WAX copied only the cross sections for the seven burnup-dependent actinides. For each of these actinides, the cross-section ID was modified by adding the cross-section set number as a prefix, to be consistent with the numbering scheme used in the SNIKR-produced KENO V.a mixingtable-format isotopics for each assembly. The WAX input listing is provided in Appendix E.

\subsection{PREPARATION OF KENO V.a CORE MODEL}

The KENO V.a model used to determine $k_{\text {eff }}$ for the North Anna 1 BOC-5 core consists of four parts. The first section of input contains code parameter specifications. The only significant aspect of this section is the use of 1003 generations of 1000 neutrons per generation; hence, the calculation was based on one million histories (three generations were automatically skipped by KENO V.a). Parameter specifications are followed by mixture specifications, geometry specifications, and plotting specifications. The plotting specifications are unimportant in the criticality calculation and were simply used in debugging and verifying geometry input. The following subsections describe the details of the material and geometry specifications for this model.

\subsubsection{KENO V.a Mixture Specifications}

In describing the composition of a fuel assembly, it has been assumed that all fuel rods in the assembly are identical and may be represented by the assembly-averaged burnup. No attempt was made to account for burnup asymmetries within an assembly, as this information was not readily available and should have little effect on the computed solution. Thus only a single fuel rod description is necessary to describe all fuel rods in a given assembly. In addition, in this model, axial power distributions are ignored, and assemblies are represented by a model that assumes a constant (average) burnup distribution along the length of the assembly. Thus the composition of fuel in an assembly is uniform and is represented by a single material specification. Based on the results of an axial end effects study, ${ }^{22}$ this assumption has a minor effect $(<0.1 \% \Delta \mathrm{k} / \mathrm{k})$ that is probably conservative for the average burnup in these models. Because it is possible to take advantage of the one-eighth-core symmetry of the core, only 26 assemblies are required to represent all 157 assembly positions in the core. Hence only 26 material mixtures are necessary for the full-core model. These mixture specifications come from the 26 assembly calculations performed earlier using SNIKR for mixtures 101 through 126. The portions of the SNIKR output copied into the KENO V.a input represent complete mixture specifications for each of the 26 materials.

Material specifications were also required for all remaining materials (i.e., clad, borated water, and BPR materials). Concentrations for each isotope were obtained from the output of the CSASN cross-section calculations. Mixture numbers 11 through 13 were used for the burnable poison materials. A unique mixture number was assigned the BPR in each eighth-core fuel assembly that contained depleted BPRs. Table 14 lists all materials included in the core model by mixture number. 
Table 14. Mixtures in KENO V.a model

\begin{tabular}{cl}
$\begin{array}{c}\text { Mixture } \\
\text { No. }\end{array}$ & \\
\hline 1 & Clad \\
2 & Description \\
3 & Borated moderator \\
4 & 50\% borated moderator, 50\% stainless steel (top and bottom reflector) \\
5 & Stainless steel (core barrel) \\
6 & Borated moderator (outside core barrel) \\
7 & Stainless steel (thermal shield) \\
8 & Borated moderator (outside thermal shield) \\
9 & Stainless steel (reactor vessel) \\
$11-13$ & Burnable poison: fresh BP for assemblies 2, 4, 6, 10, 12, 17, 19, 22; \\
$101-126$ & depleted BP for assembly 11; depleted BP for assembly 14 \\
\hline
\end{tabular}

\subsubsection{KENO V.a Geometry Specifications}

A fuel rod was defined for each of the 26 one-eighth-core fuel assemblies based on the dimensions given in Table 4. Identical dimensions were used for all rod specifications. Fuel rods were assigned to Unit Numbers 101 to 126 , respectively; the fuel region of each rod was linked to its corresponding material number (e.g., fuel rod 101 used material 101 for the fuel region). All rods were specified with a void gap and Zircaloy clad, centered in a water cuboid. Fuel rods and enclosing cuboids were modeled as having a length equal to that of the active fuel length of the rod (i.e., fuel assembly top and bottom structures were neglected). A 50:50 mixture of borated $\mathrm{H}_{2} \mathrm{O}$ and stainless steel was used as a top and bottom reflector $(25 \mathrm{~cm}$ thick) to account for structural materials above and below the active fuel region.

Unit 161, representing a control rod guide tube, was created using the dimensions in Table 4, with water inside the tube and centered within a water cuboid. Burnable poison rods were created as Units 162-164. Each BPR was put inside a control rod guide tube.

A $17 \times 17$ array was then defined for each of the 26 fuel assemblies, which were assigned Unit numbers 1-26 corresponding to their eighth-core location. The 264 fuel rod locations in each assembly were filled with the fuel rod containing the assembly average isotopics. The remaining array locations were appropriately filled with guide tubes or BPRs according to the full-core BPR loading configuration in Fig. 5 and the fuel assembly lattice arrangements in Fig. 4. Each array was surrounded by a thin layer of moderator to obtain an assembly lattice spacing of $21.50364 \mathrm{~cm}$ (8.466 in.).

The core baffle surrounding the outermost assemblies was created as a composite of several smaller segments, comprised of four different cuboid shapes. Units 41 to 44 were used to define 
these shapes. Figure 7 illustrates the use of these four unit types in modeling the core baffle. The figure also shows assembly position numbers for the full core, based on one-eighth-core symmetry and the numbering scheme shown in Fig. 6 . Using these position numbers, arrays of assemblies and core baffle segments were used to define larger units, to minimize the number of KENO V.a "holes" placed in the global unit. Figure 8 illustrates the grouping of assemblies used. Global Unit 70 contained the core barrel, thermal shield, and reactor vessel. All other units were placed within Unit 70 using KENO V.a "holes." Note that core baffle components drawn in black in the figure represent individual components not included in these arrays and were entered as individual holes in the global array. Unit number assignments used in the model are given in Table 15.

This completes the geometric description of the core. As a reference, a listing of the entire KENO V.a input for the BOC-5 HZP case is included in Appendix F. 

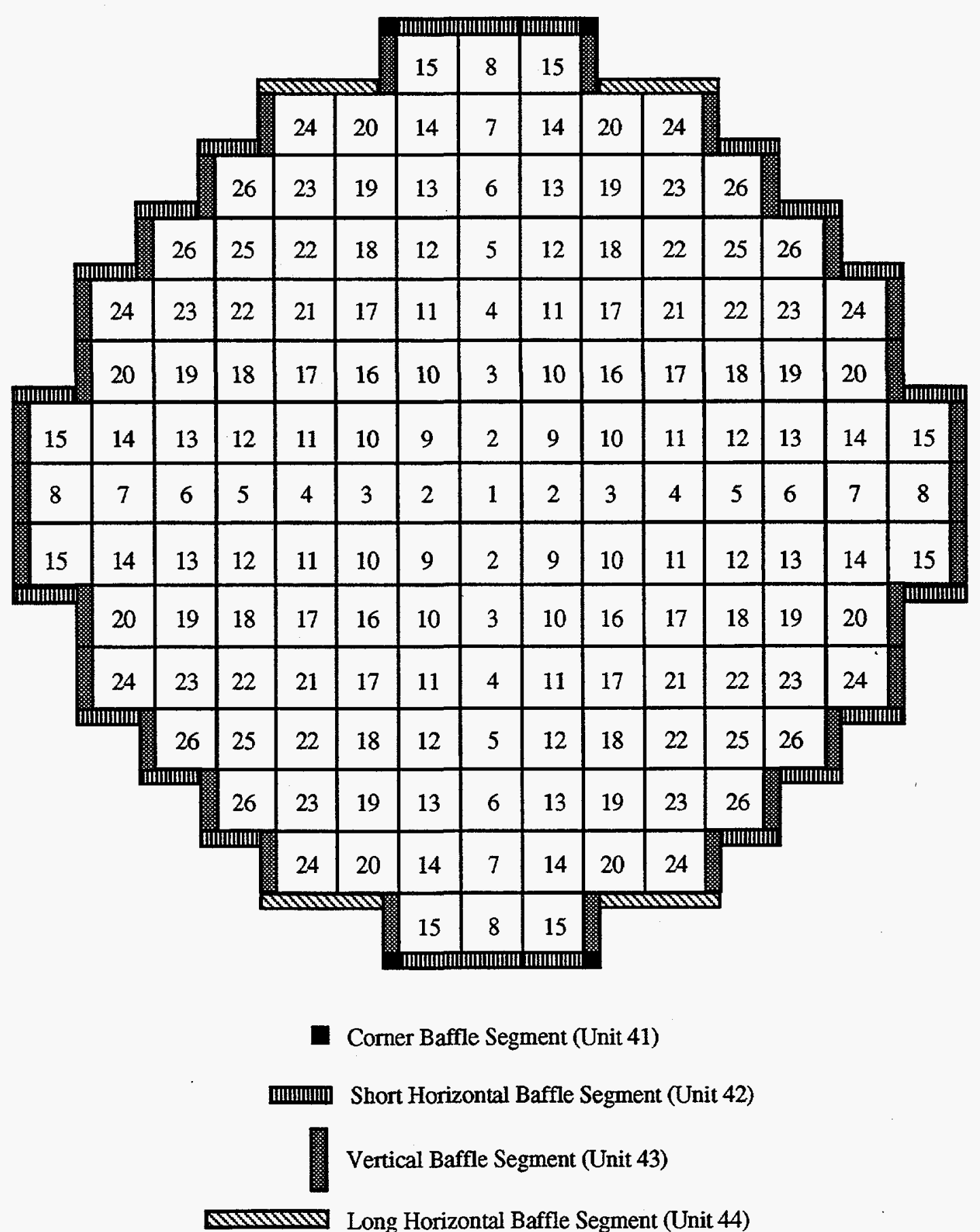

Fig. 7. Full-core-assembly positions and core baffle configuration. 


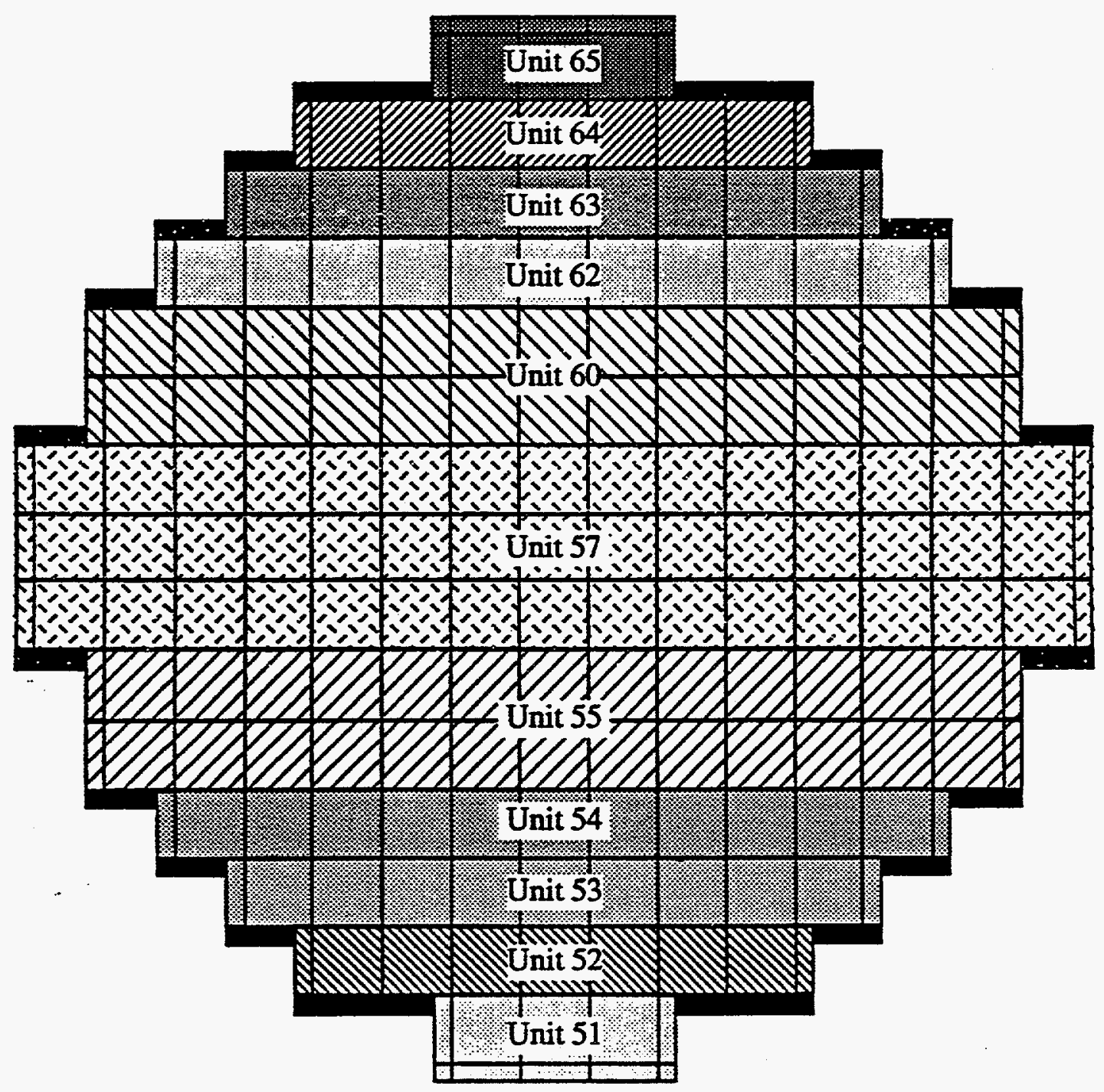

Fig. 8. KENO V.a unit definitions based on component arrays. 
Table 15. Unit numbers used in North Anna KENO V.a core model

\begin{tabular}{ll}
\hline $\begin{array}{l}\text { Unit } \\
\text { No. }\end{array}$ & \multicolumn{1}{c}{ Description } \\
\hline $1-26$ & Fuel assemblies for positions 1 to 26 , respectively \\
41 & $1.905 \times 1.905 \mathrm{~cm}$ (corner) segment of core baffle \\
42 & $21.50364 \times 1.905 \mathrm{~cm}$ (horizontal) segment of core baffle \\
43 & $1.905 \times 21.50364 \mathrm{~cm}$ (vertical) segment of core baffle \\
44 & $43.00728 \times 1.905 \mathrm{~cm}$ (horizontal) segment of core baffle \\
51 & "Bottom" of baffle + row 1 of assemblies + vertical baffle ends \\
52 & Row 2 of assemblies + vertical baffle ends \\
53 & Row 3 of assemblies + vertical baffle ends \\
54 & Row 4 of assemblies + vertical baffle ends \\
55 & Rows 5 and 6 of assemblies + vertical baffle ends \\
57 & Rows $7-9$ of assemblies + vertical baffle ends \\
60 & Rows 10 and 11 of assemblies + vertical baffle ends \\
62 & Row 12 of assemblies + vertical baffle ends \\
63 & Row 13 of assemblies + vertical baffle ends \\
64 & Row 14 of assemblies + vertical baffle ends \\
65 & Row 15 of assemblies + vertical baffle ends + "top" of baffle \\
70 (GLOBAL) & Reactor vessel + thermal shield + core barrel + vertical baffle ends \\
$101-126$ & Fuel rods for assemblies 1-26, respectively \\
161 & Water-filled control rod guide tube \\
$162-164$ & BPRs in control rod guide tubes \\
\hline
\end{tabular}




\section{RESULTS AND CONCLUSIONS}

The KENO V.a criticality calculations for the North Anna 1 Cycle 5 BOC model described in this report yielded a value for $k_{\text {eff }}$ of $1.0040 \pm 0.0005$. The results are based on 1000 generations of 1000 neutrons per generation, for a total of $1 \times 10^{6}$ histories. The average fission group reported by SCALE, representing the average neutron energy at which fission occurs, was calculated to be $20.3838 \pm 0.0038$. For the 27-group burnup library, group 20 spans the energy range 0.4 to $0.8 \mathrm{eV}$. Numerical experiments with a different starting random number and different starting source shape and location indicate that these solutions are well converged and adequate source sampling achieved (see ref. 7 for a discussion of what constitutes convergence).

The relative fission density distribution (normalized to the core-average value) computed by KENO V.a is shown in Fig. 9 for a one-eighth-core average. These data may be interpreted as relative power densities and show the approximate shape expected for an operating PWR core, indicating no major anomalies in the core assembly model. Note that even though $\mathrm{k}_{\text {eff }}$ a total system parameter, is considered to be well converged, individual assembly fission distributions are based on substantially fewer histories, especially in outer-core regions, and therefore are subject to significantly higher uncertainties.

These $\mathrm{k}_{\text {eff }}$ results are approximately $2 \% \Delta \mathrm{k} / \mathrm{k}$ greater than those reported for the North Anna and North Anna reactor critical benchmark calculations ${ }^{8}$ performed with the original SCALE scoping calculations but are consistent with the results performed with the revised methodology as summarized in Vol. 1 of this report. Differences in the earlier analyses that have been identified and their probable order of importance are use of a lumped fission product to account for all nuclides not explicitly modeled, fewer fuel batches and cross-section sets, fewer neutrons per generation and fewer total neutron histories, and use of an earlier version of SAS2H. The consistency in results for the revised methodology and its straightforward procedure for calculating isotopics provide a high level of confidence in these results. The complexity in the isotopic calculational procedure of the initial methodology, the use of lumped fission products, and the inability to reproduce results due to loss of data from the earlier work reduces confidence in the original calculations.

The results of these calculations demonstrate that even with a relatively simple core model using eighth-core assembly-averaged burnups, it is possible to closely predict, in a best-estimate fashion, the critical condition for a lattice primarily comprised of spent fuel assemblies. Results are also consistent with SCALE validation calculations performed based on experiments using mixedoxide fuel rods in square lattice configurations. ${ }^{23}$ Hence one may conclude that the methodology applied in performing these reactor critical calculations is valid for performing criticality safety analyses for systems with spent fuel. 


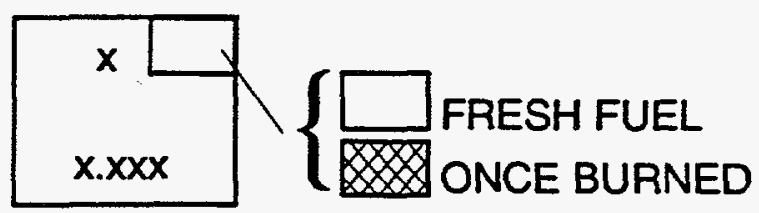

1/8 CORE ASS'Y LOCATION

RELATIVE FISSION DENSITY

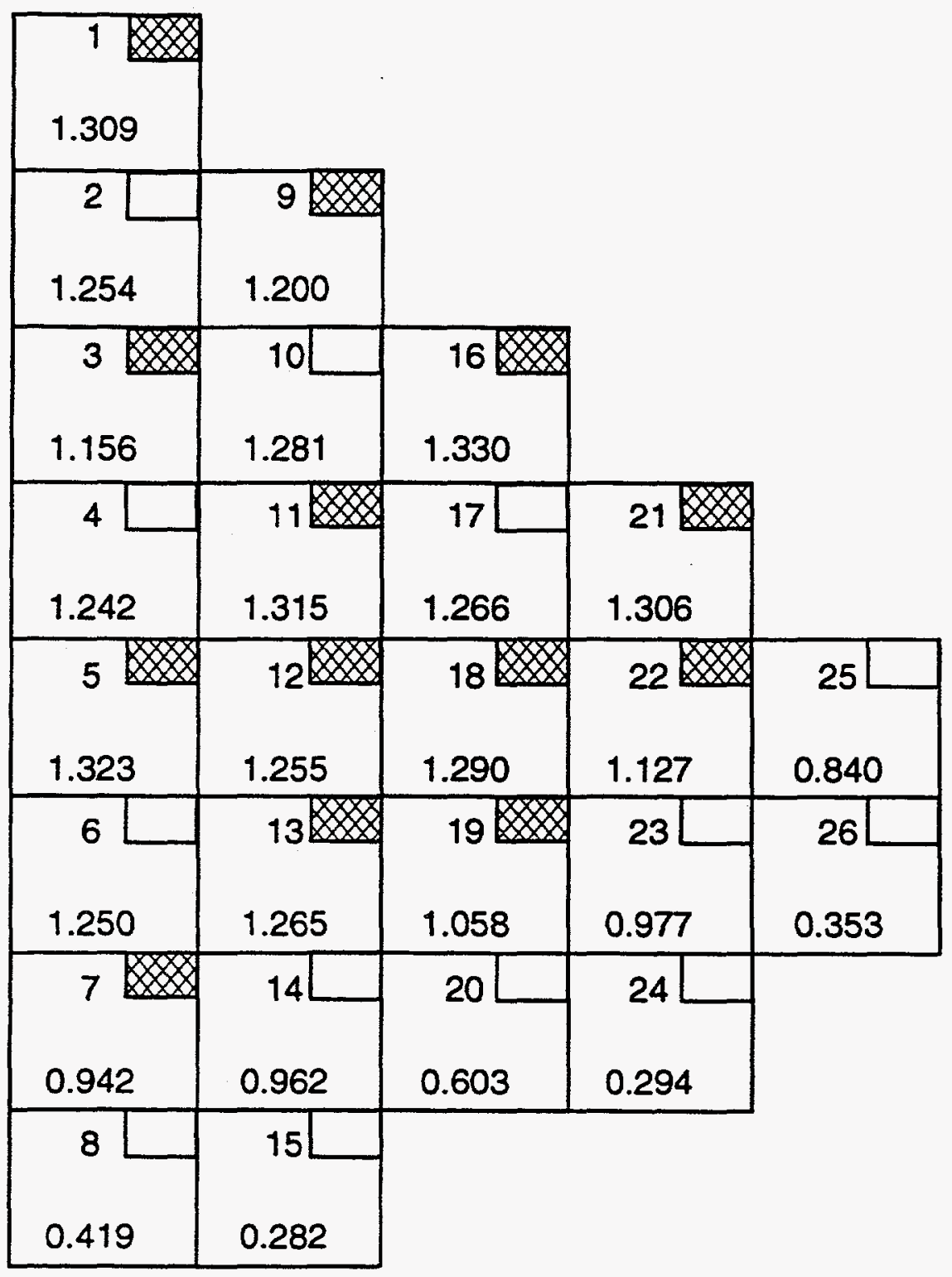

Fig. 9. BOC, HZP eighth-core relative fission density distribution. 


\section{REFERENCES}

1. T. L. Sanders and R. M. Westfall, "Feasibility and Incentives for Burnup Credit in Spent Fuel Transport Casks," Nucl. Sci. Eng. 104 (1990).

2. "American National Standard for Nuclear Criticality Safety in Operations with Fissionable Materials Outside Reactors," ANSI/ANS-8.1-1983.

3. SCALE: A Modular Code System for Performing Standardized Computer Analyses for Licensing Evaluation, NUREG/CR-0200, Rev. 4 (ORNL/NUREG/CSD-2/R4), Vols. 1, 2, and 3 (February 1995). Available from Radiation Shielding Information Center as CCC545.

4. M. C. Brady and T. L. Sanders, "A Validated Methodology for Evaluating Burnup Credit in Spent Fuel Casks," Proc. of International Conference on Nuclear Criticality Safety, Christ Church, Oxford, United Kingdom, September 9-31, 1991.

5. O. W. Hermann and C. V. Parks, "SAS2H: A Coupled One-Dimensional Depletion and Shielding Analysis Code," Sect. S2 of SCALE: A Modular Code System for Performing Standardized Computer Analyses for Licensing Evaluation, NUREG/CR-0200, Rev. 4 (ORNL/NUREG/CSD-2/R4), Vols. 1, 2 and 3 (February 1995). Available from Radiation Shielding Information Center as CCC-545.

6. N. F. Landers and L. M. Petrie, "CSAS4: An Enhanced Criticality Safety Analysis Module with an Optimum Pitch Search Option" Sect. C4 of SCALE: A Modular Code System for Performing Standardized Computer Analyses for Licensing Evaluation, NUREG/CR0200, Rev. 4 (ORNL/NUREG/CSD-2/R4), Vols. 1, 2 and 3 (February 1995). Available from Radiation Shielding Information Center as CCC-545.

7. L. M. Petrie and N. F. Landers, "KENO V.a: An Improved Monte Carlo Criticality Program with Supergrouping," Sect. F11 of SCALE: A Modular Code System for Performing Standardized Computer Analyses for Licensing Evaluation, NUREG/CR0200, Rev. 4 (ORNL/NUREG/CSD-2/R4), Vols. 1, 2, and 3 (February 1995). Available from Radiation Shielding Information Center as CCC-545.

8. J.-P. Renier and C. V. Parks, "Reactor Critical Calculations for Validation of Burnup Credit Analysis Methods," Trans. Am. Nucl. Soc. 62, 308 (1990).

9. O. W. Hermann and R. M. Westfall, "ORIGEN-S: A SCALE System Module to Calculate Fuel-Depletion, Actinide Transmutation, Fission Product Buildup and Decay, and Associated Radiation Source Terms," Sect. F7 of SCALE: A Modular Code System for Performing Standardized Computer Analyses for Licensing Evaluation, NUREG/CR0200, Rev. 4 (ORNL/NUREG/CSD-2/R4), Vols. 1, 2 and 3 (February 1995). Available from Radiation Shielding Information Center as CCC-545. 
10. B. H. Wakeman and S. A. Ahmed, Evaluation of Burnup Credit for Dry Storage Casks, EPRI NP-6494, Electric Power Research Institute, August 1989.

11. O. W. Hermann and M. C. Brady, Comparisons of SAS2H and CASMO-3 Benchmark $k_{\infty}$ Calculations for Reactor Fuel With and Without Burnable Poisons, ORNL/TM-12490, Martin Marietta Energy Systems, Inc., Oak Ridge Natl. Lab. (to be published).

12. B. L. Broadhead et al., Investigation of Nuclide Importance to Functional Requirements Related to Transport and Long-Term Storage of LWR Spent Fuel, ORNL/TM-12742, Martin Marietta Energy Systems, Inc., Oak Ridge Natl. Lab. (to be published).

13. D. G. Napolitano and D. G. Adli, Burnup Credit Criticality Analysis Using Advanced Nodal Techniques, Yankee Atomic Electric Co., March 1992.

14. N. M. Greene, "BONAMI-S: Resonance Self-Shielding by the Bondarenko Method," Sect. F1 of SCALE: A Modular Code System for Performing Standardized Computer Analyses for Licensing Evaluation, NUREG/CR-0200, Rev. 4 (ORNL/NUREG/ CSD2/R4), Vols. 1, 2, and 3 (February 1995). Available from Radiation Shielding Information Center as CCC-545.

15. N. M. Greene, L. M. Petrie, and R. M. Westfall, "NITAWL-II: SCALE System Module for Performing Resonance Shielding and Working Library Production," Sect. F2 of SCALE: A Modular Code System for Performing Standardized Computer Analyses for Licensing Evaluation, NUREG/CR-0200, Rev. 4 (ORNL/NUREG/ CSD-2/R4), Vols. 1, 2 and 3 (February 1995). Available from Radiation Shielding Information Center as CCC545.

16. N. M. Greene, "User's Guide for Utility Modules," Sect. M15 of SCALE: A Modular Code System for Performing Standardized Computer Analyses for Licensing Evaluation, NUREG/CR-0200, Rev. 4 (ORNL/NUREG/CSD-2/R4), Vols. 1, 2 and 3 (February 1995). Available from Radiation Shielding Information Center as CCC-545.

17. C. B. LaRoe, A. Abbasi, North Anna Unit I Cycle 5 Design Report, N. E. Technical Report No. 384, Virginia Electric and Power Company (July 1984).

18. S. M. Bowman, O. W. Hermann, and M. C. Brady, SCALE-4 Analysis of Pressurized Water Reactor Critical Configurations: Volume 2 - Sequoyah Unit 2 Cycle 3, ORNL/TM-12294, Vol. 2, Martin Marietta Energy Systems, Inc., Oak Ridge Natl. Lab., March 1995.

19. O. W. Hermann, J-P. Renier, and C. V. Parks, Technical Support for a Proposed Decay Heat Guide Using SAS2H/ORIGEN-S Data, NUREG/CR-5625 (ORNL-6698), Martin Marietta Energy Systems, Inc., Oak Ridge Natl. Lab., September 1994. 
20. G. W. Morey, The Properties of Glass, 2nd ed., Reinhold, New York, 1954.

21. F. W. Walker, J. R. Parrington, and F. Feiner (revisors of edition), Nuclides and Isotopes, 14th ed., General Electric Co., San Jose, California, 1989.

22. S. E. Turner, "An Uncertainty Analysis-Axial Burnup Distribution Effects," Proc. Workshop Use of Burnup Credit in Spent Fuel Transport Casks, Washington, D.C., February 21-22, 1988, SAND89-0018, TTC-0884, UC-820, T. L. Sanders, Ed., Sandia National Laboratories, October 1989.

23. S. M. Bowman et al., "Validation of SCALE-4 for Burnup Credit Applications," Nucl. Tech. 110, 3 . 


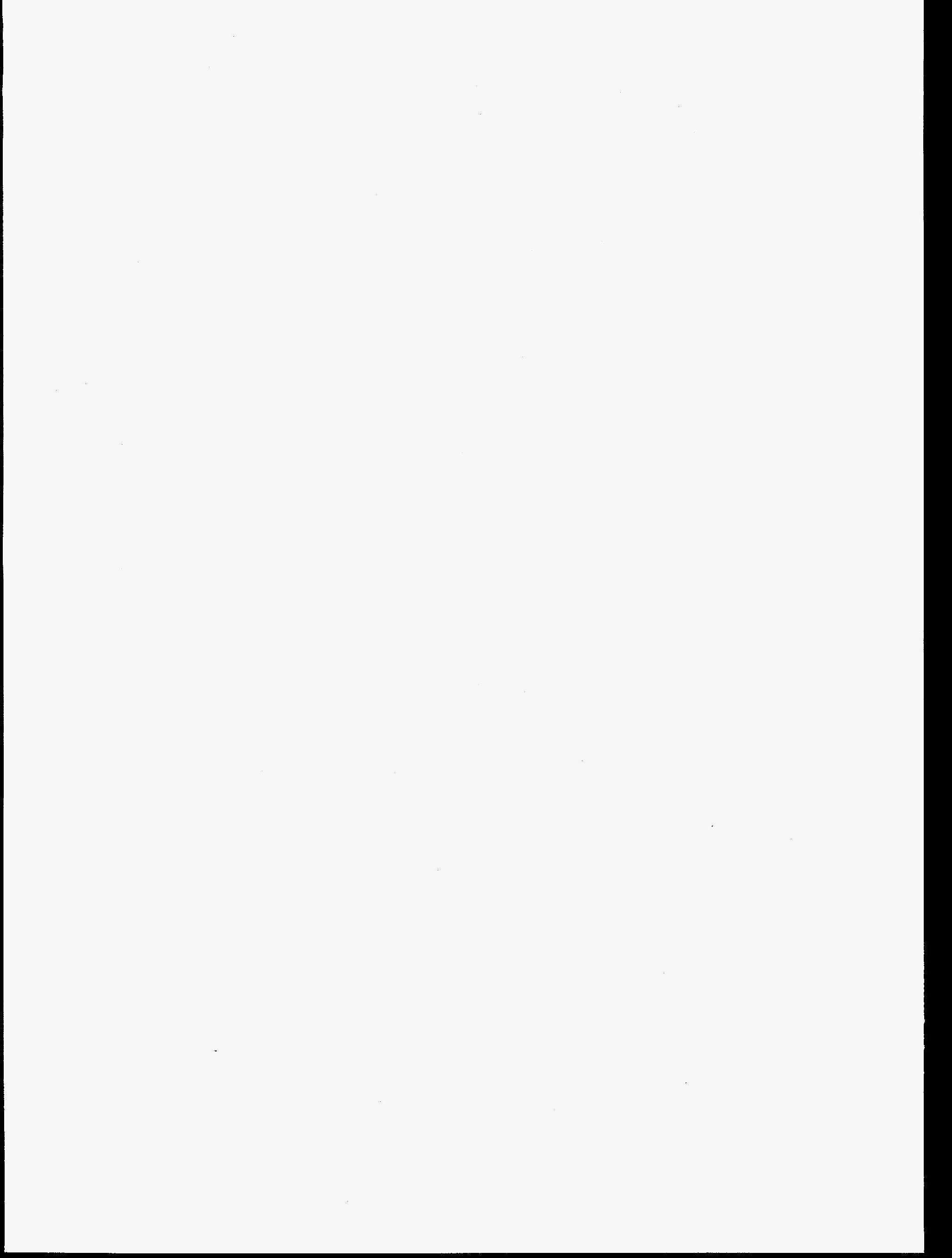




\section{APPENDIX A \\ NORTH ANNA UNIT 1 CYCLE 5 DATA}

The initial core loading pattern of Cycle 5 is shown in Fig. A.1. The initial and final burnup distributions in the core for Cycle 5 are listed in Table A.1. The assemblies are grouped in the table into the eighth-core symmetric sets as loaded in Cycle 5. 


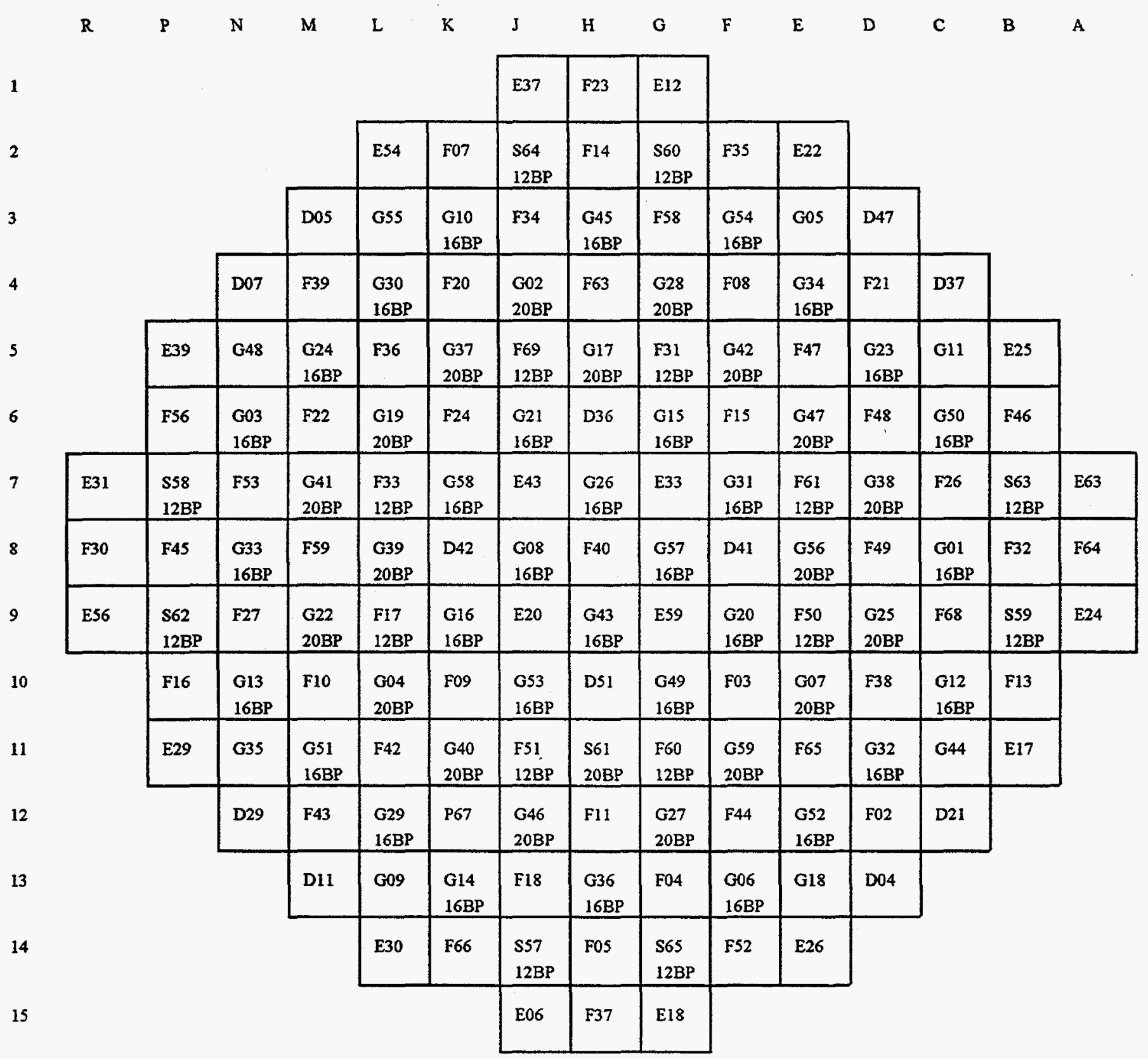

Fig. A.1. North Anna Unit 1 Cycle 5 core loading pattern. 
Table A.1. Fuel assembly burnups at BOC for North Anna Unit 1 Cycle 5

\begin{tabular}{|c|c|c|c|c|c|}
\hline $\begin{array}{l}\text { Assembly } \\
\text { ID }\end{array}$ & Batch & $\begin{array}{c}\text { Burnup } \\
\text { (MWd/MTU) }\end{array}$ & $\begin{array}{l}\text { Assembly } \\
\text { ID }\end{array}$ & Batch & $\begin{array}{c}\text { Burnup } \\
\text { (MWd/MTU) }\end{array}$ \\
\hline$\overline{\mathrm{D} 04}$ & 4 & 21732 & $\mathrm{Fl4}$ & 6 & 12870 \\
\hline D05 & 4 & 21191 & $\mathrm{~F} 15$ & 6 & 13206 \\
\hline D07 & 4 & 21611 & Fl6 & 6 & 12008 \\
\hline Dll & 4 & 21439 & F17 & 6 & 11904 \\
\hline $\mathrm{D} 21$ & 4 & 25272 & F18 & 6 & 12022 \\
\hline D29 & 4 & 27402 & F20 & 6 & 12621 \\
\hline D36 & 4 & 26307 & F21 & 6 & 15892 \\
\hline D37 & 4 & 27427 & $\mathrm{~F} 22$ & 6 & 15899 \\
\hline D41 & 4 & 26415 & F23 & 6 & 15887 \\
\hline D42 & 4 & 26573 & $\mathrm{~F} 24$ & 6 & 15730 \\
\hline D47 & 4 & 26829 & F26 & 6 & 15937 \\
\hline D51 & 4 & 27631 & $\mathrm{~F} 27$ & 6 & 16049 \\
\hline E06 & 5 & 21047 & F30 & 6 & 15926 \\
\hline E12 & 5 & 21002 & F31 & 6 & 15805 \\
\hline $\mathrm{E} 17$ & 5 & 20992 & F32 & 6 & 15575 \\
\hline E18 & 5 & 20764 & F33 & 6 & 15620 \\
\hline E20 & 5 & 30537 & F34 & 6 & 15756 \\
\hline E22 & 5 & 30731 & F35 & 6 & 15747 \\
\hline E24 & 5 & 30766 & F36 & 6 & 17105 \\
\hline E25 & 5 & 30471 & F37 & 6 & 17248 \\
\hline E26 & 5 & 30478 & F38 & 6 & 17191 \\
\hline E29 & 5 & 30827 & F39 & 6 & 17010 \\
\hline E30 & 5 & 30943 & F40 & 6 & 17182 \\
\hline E31 & 5 & 30164 & $\mathrm{~F} 42$ & 6 & 17196 \\
\hline E33 & 5 & 32157 & F43 & 6 & 17055 \\
\hline E37 & 5 & 32152 & F44 & 6 & 17655 \\
\hline E39 & 5 & 32200 & F45 & 6 & 17382 \\
\hline $\mathrm{E} 43$ & 5 & 32077 & F46 & 6 & 17546 \\
\hline E54 & 5 & 32015 & $\mathrm{~F} 47$ & 6 & 17490 \\
\hline E56 & 5 & 32122 & F48 & 6 & 17208 \\
\hline E59 & 5 & 32110 & F49 & 6 & 17317 \\
\hline E63 & 5 & 31554 & F50 & 6 & 17023 \\
\hline F02 & 6 & 10012 & F51 & 6 & 16784 \\
\hline F03 & 6 & 9846 & F52 & 6 & 16920 \\
\hline F04 & 6 & 9831 & F53 & 6 & 16873 \\
\hline F05 & 6 & 9513 & F56 & 6 & 16707 \\
\hline F07 & 6 & 13382 & F58 & 6 & 16762 \\
\hline F08 & 6 & 12644 & F59 & 6 & 16771 \\
\hline F09 & 6 & 11907 & F60 & 6 & 16810 \\
\hline F10 & 6 & 12814 & F61 & 6 & 13932 \\
\hline F11 & 6 & 13304 & F63 & 6 & 14347 \\
\hline F13 & 6 & 12995 & F64 & 6 & 14172 \\
\hline
\end{tabular}


Table A.1. (continued)

\begin{tabular}{|c|c|c|c|c|c|}
\hline $\begin{array}{l}\text { Assembly } \\
\text { ID }\end{array}$ & Batch & $\begin{array}{c}\text { Burnup } \\
\text { (MWd/MTU) }\end{array}$ & $\begin{array}{l}\text { Assembly } \\
\text { ID }\end{array}$ & Batch & $\begin{array}{c}\text { Burnup } \\
\text { (MWd/MTU) }\end{array}$ \\
\hline$\overline{\text { F65 }}$ & 6 & 13886 & G31 & 7 & 17338 \\
\hline F66 & 6 & 14131 & G32 & 7 & 17246 \\
\hline F67 & 6 & 14145 & G33 & 7 & 17071 \\
\hline F68 & 6 & 13944 & G34 & 7 & 16731 \\
\hline F69 & 6 & 14094 & G35 & 7 & 16975 \\
\hline G01 & 7 & 13540 & G36 & 7 & 16727 \\
\hline G02 & 7 & 13371 & G37 & 7 & 17097 \\
\hline G03 & 7 & 13191 & G38 & 7 & 17003 \\
\hline G04 & 7 & 13358 & G39 & 7 & 16868 \\
\hline G05 & 7 & 13353 & G40 & 7 & 16771 \\
\hline G06 & 7 & 13541 & G41 & 7 & 15737 \\
\hline G07 & 7 & 13044 & G42 & 7 & 15641 \\
\hline G08 & 7 & 13385 & G43 & 7 & 15957 \\
\hline G09 & 7 & 18084 & G44 & 7 & 15695 \\
\hline G10 & 7 & 18116 & G45 & 7 & 16033 \\
\hline Gll & 7 & 17679 & G46 & 7 & 15919 \\
\hline G12 & 7 & 17913 & G47 & 7 & 15730 \\
\hline G13 & 7 & 18009 & G48 & 7 & 15737 \\
\hline G14 & 7 & 17593 & G49 & 7 & 16170 \\
\hline G15 & 7 & 17838 & G50 & 7 & 16183 \\
\hline G16 & 7 & 18010 & G51 & 7 & 16226 \\
\hline G17 & 7 & 18038 & G52 & 7 & 16199 \\
\hline G18 & 7 & 17500 & G53 & 7 & 14752 \\
\hline G19 & 7 & 17620 & G54 & 7 & 14843 \\
\hline G20 & 7 & 17728 & G55 & 7 & 14988 \\
\hline G21 & 7 & 17525 & G56 & 7 & 15090 \\
\hline G22 & 7 & 16991 & G57 & 7 & 14661 \\
\hline G23 & 7 & 17218 & G58 & 7 & 14754 \\
\hline G24 & 7 & 16976 & G59 & 7 & 14809 \\
\hline G25 & 7 & 17441 & S57 & $\mathrm{N} 2 / 5$ & 15037 \\
\hline G26 & 7 & 17349 & S58 & $\mathrm{N} 2 / 5$ & 13276 \\
\hline G27 & 7 & 17305 & S59 & $\mathrm{N} 2 / 5$ & 12693 \\
\hline G28 & 7 & 17297 & S60 & $\mathrm{N} 2 / 5$ & 12918 \\
\hline G29 & 7 & 17408 & S61 & $\mathrm{N} 2 / 5$ & 12790 \\
\hline \multirow[t]{4}{*}{ G30 } & 7 & 17409 & S62 & $\mathrm{N} 2 / 5$ & 12530 \\
\hline & & & S63 & $\mathrm{N} 2 / 5$ & 12740 \\
\hline & & & S64 & $\mathrm{N} 2 / 5$ & 12841 \\
\hline & & & S65 & $\mathrm{N} 2 / 5$ & 12606 \\
\hline
\end{tabular}


APPENDLX B

SAS2H CASE INPUT LISTING 
=sas2 parm='hal t08, skipshipdata'

sas2h: north anna critical isotopes, batch 5, 5gwd/mtu int, $\times 8$ cycles 27burnuplib latticecell

เ

mixtures of fuel-pin-unit-cell:

uo2 10.9458901922340 .029922353 .41922360 .0169223896 .545 end

kr-83 $1001-20901$ end

$k r-85 \quad 1 \quad 0 \quad 1-20901$ end

sr-90 $11001-20901$ end

$y-89 \quad 1 \quad 001-20901$ end

mo-95 $1001-20901$ end

$\begin{array}{lllll}z r-93 & 1 & 0 & 1-20 & 901 \\ & \text { end }\end{array}$

$\begin{array}{lllll}2 r-94 & 1 & 0 & 1-20 & 901 \\ & \text { end }\end{array}$

$2 r-95 \quad 1 \quad 0 \quad 1-20901$ end

nb-94 $1001-20901$ end

tc-99 $1001-20901$ end

$r h-103 \quad 1 \quad 0 \quad 1-20901$ end

rh-105 $1001-20901$ end

ru-101 1 1 $011-20901$ end

ru-106 $1001-20901$ end

pd-105 1 0 $1-20901$ end

pd-108 $1001-20901$ end

ag-109 $100 \quad 1-20901$ end

sb-124 $100 \quad 1-20901$ end

$i-135 \quad 1 \quad 0 \quad 1-20901$ end

$x e-131 \quad 1 \quad 0 \quad 1-20901$ end

$x e-132 \quad 1 \quad 0 \quad 1-20901$ end

$x e-135 \quad 1 \quad 0 \quad 6-9 \quad 901$ end

$x e-136 \quad 1 \quad 0 \quad 1-20901$ end

cs-133 $1001-20901$ end

cs-134 $1001-20901$ end

cs-135 $1001-20901$ end

cs-137 $1001-20901$ end

ba-136 $1001-20901$ end

la-139 $1001-20901$ end

pr-141 $1001-20901$ end

pr-143 $1001-20901$ end

ce-144 $1001-20901$ end

nd-143 $1001-20901$ end

nd-145 $1001-20901$ end

$\mathrm{pm}-147 \quad 1 \quad 0 \quad 1-20901$ end

pm-148 $100 \quad 1-20901$ end

pm-149 $1001-20901$ end

nd-147 $1001-20901$ end

sm-147 $1001-20901$ end

sm-149 $1001-20901$ end

sm-150 $1001-20901$ end

$\mathrm{sm}-151 \quad 1 \quad 0 \quad 1-20901$ end

sm-152 $1001-20901$ end

gd-155 $1001-20901$ end

eu-153 $1001-20901$ end

eu-154 $1001-20901$ end

eu-155 $1001-20901$ end

zircalloy 21629 end

h2o 3 den $=0.70411583$ end

arbm-bormod $0.7041110050001003575 .0 \mathrm{e}-6583$ end

1 $575 \mathrm{pn}(\mathrm{wt}$ ) boron (550 ppm at cycle 3 and $600 \mathrm{ppm}$ at cycle 4)

end comp

,

'

- fuel-pin-cell geometry:

squarepitch 1.259840 .81915130 .9499620 .835660 end

I 
more data $s z f=0.6$ end

1

।

assembly and cycle parameters:

npin/assm $=264$ fuelngth $=790.81$ ncycles $=8$ nlib/cyc=1

printlevel $=4$ lightel $=9 \quad$ inplevel $=1$

numinstr $=1$ ortube $=0.61214$ srtube $=0.5715$ and

power $=31.023$ burn=161.17 down=31.62 end

power $=31.023$ burn=161.17 down=31.62 end

power $=31.023$ burn=161.17 down $=31.62$ end

power $=31.023$ burn=161.17 down=31.62 end

power $=31.023$ burn $=161.17$ down $=31.62$ end

power $=31.023$ burn=161.17 down $=31.62$ end

power $=31.023$ burn=161.17 down $=31.62$ end

power $=31.023$ burn $=161.17$ down $=0$ end

- 135 or 5.9 mn 0.33

fe 12.9 co 0.075 ni 9.9

zr 221 nb 0.71 sn 3.6

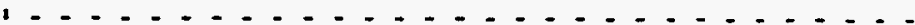

end 


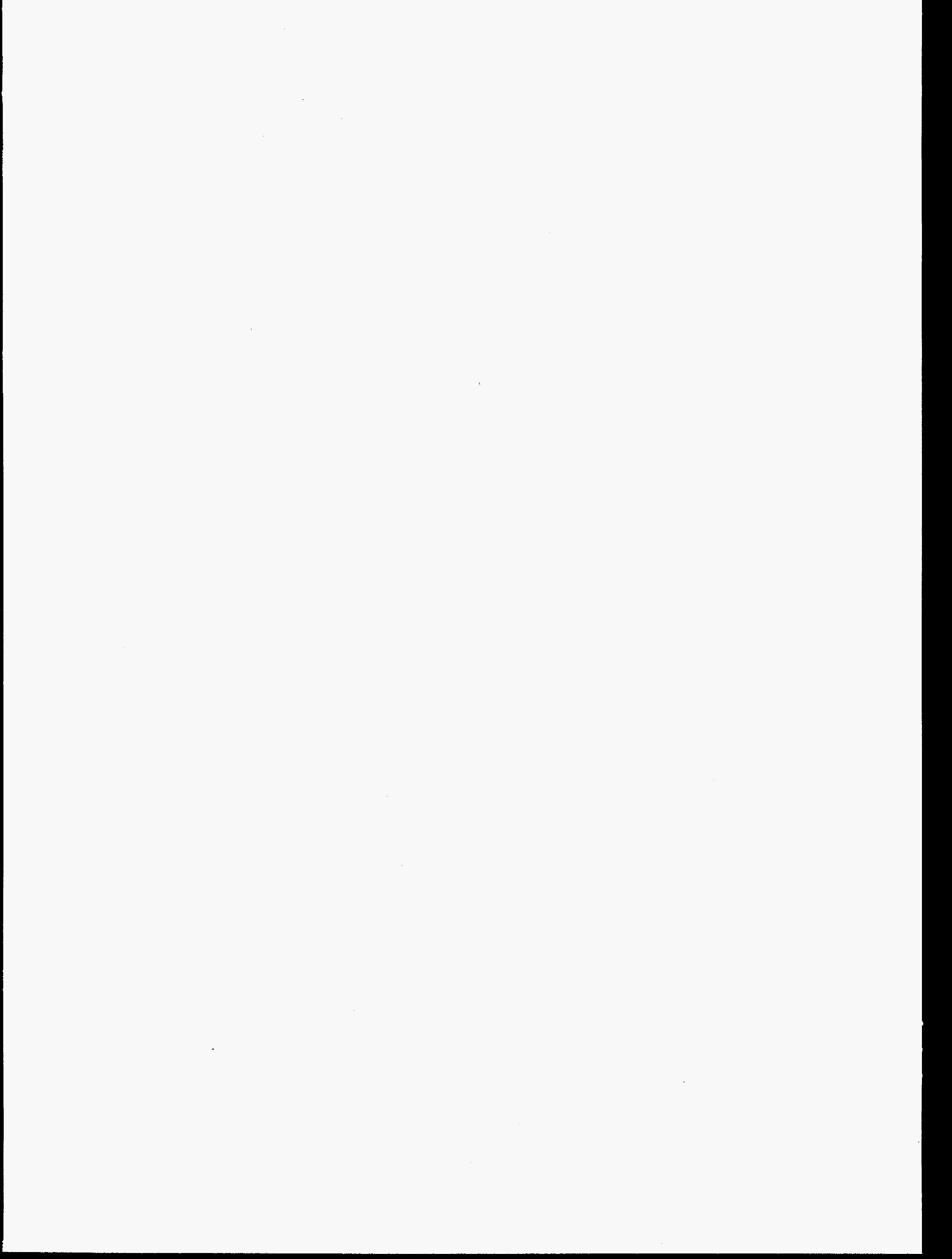


APPENDLX C

SNIKR VERSION 1.0 DOCUMENTATION 


\section{SNIKR VERSION 1.0 USER'S INPUT GUIDE}

Each entry below must begin in column 1. Recommended values are given in parentheses.

Line 1

$$
\text { SNIKR1 }
$$

Line 2 Title card for SNIKR1 (80-character maximum)

Line $3 \quad$ READ BURNUP

Line $4 \quad$ N72=ii (I2 format)

Unit number for SAS2H atom density file (72)

Line $5 \quad$ NOUT $=$ ii (I2 format)

Unit number for SNIKR1 output file (70)

Line 6

BURN=xxxxxx.x (F8.1 format)

Desired burnup in MWd/MTU for interpolation

Line $7 \quad \mathrm{NCYC}=\mathrm{ii}$ (I2 format)

Number of cycles in SAS2H depletion

Line $8 \quad$ END BURNUP

Line $9 \quad$ READ DECAY

Line 10 NORS=ii (12 format)

Unit number for ORIGEN-S input file created by SNIKRI (74)

Line $11 \quad \mathrm{~N} 71=\mathrm{ii}$ (I2 format)

Unit number to which ORIGEN-S will write the restart file containing the isotopic data at the requested cooling times. This file will then be read by SNIKR3 (71)

Line 12 COOLTME $=x x x . x x$ (F6.2 format)

Cooling time in years at which isotopics are desired

Line 13 LIGHTEL=ii (I2 format)

Number of light-element nuclides for which isotopics are desired. Data will be read after "END DECAY." This option allows the user to extract light-element data in addition to actinide and fission-product data and/or to adjust the concentrations of light-element nuclides. 


\section{Line 14 END DECAY}

If LIGHTEL > 0, enter the following data for each light-element nuclide (free format):

a. Nuclide ID number

b. Atom density of nuclide

c. Option flag

$1=$ replace $\mathrm{SAS} 2 \mathrm{H}$ atom density with value entered above

$2=$ replace SAS2H atom density only if SAS2H value is zero

$3=$ add the atom density to the SAS2H value. Using this option and an atom density of zero above will extract data from SAS2H without modification.

\section{Line 15 SNIKR3}

Line 16 Title card for SNIKR3 (80-character maximum)

Line 17 READ MXFUEL

Line 18 N71=ii (12 format)

Unit number from which SNIKR3 will read the ORIGEN-S restart file containing the isotopic data at the requested cooling times (71)

Line 19 NICE=ii (I2 format)

Unit number to which SNIKR3 writes the data for input to ICE (75)

Line 20 NOUT3=ii (I2 format)

Unit number to which SNIKR3 writes the data in SCALE standard composition and KENO V.a mixing table input formats (73)

Line 21 NCOOL=ii (I2 format)

Cooling time step in ORIGEN-S output from which isotopic data are to be extracted

Line 22 FISPROD=iii (I3 format)

Actinide and fission-product nuclides for which isotopic data are to be extracted

$0=25$ burnup credit nuclides from ref. 4

$-1=37$ burnup credit nuclides from ref. 1

$-2=48$ nuclides used in reactor critical calculations (Table 2)

$-3=193$ nuclides (all nuclides in 27-group burnup library)

$\mathrm{N}=$ Read $\mathrm{N}$ nuclides specified by user after "END MXFUEL"

Line 23 MIXF=iiii (I4 format)

Mixture number for SCALE standard composition input 
Line 24 IDMOD=ii (I2 format)

Fuel nuclide ID modifier for seven burnup-dependent actinides

Line 25 END MXFUEL

If FISPROD $>0$, enter the nuclide IDs here. (Format 10(1X,I5)) 


\section{C.2 SNIKR1 FORTRAN LISTING}

c

program snikr 1

common /const/ beonv, burn, cool, mixf, idmod, smacto

common /index/ nburn, nerit, nlitl, ile, iact, ifp, i tot, ncyc

common /untnos/ n72, nout, n71, nors, nice

common /ident/ idlitl(40), idcrit(200), iddk (2000)

common /adens/ adl itl(40), ltyp(40), adcrit (200), addk(2000)

cormon /title/ ittl( 20$)$

dimension tstep(10)

c read input to snikr needed to set up ors runs

data tstep/0.08,0.25,0.5, 1.0,2.0,3.0,5.0,10,15,20/

call 1 rdinpt 1

c

c write input to nout

write(nout, 120) ittl

write(nout, 130)n72

write(nout, 140) nout

write(nout, 150)burn

write(nout, 160)bconv

write(nout, 170)ncyc

write(nout, 140)nors

write(nout, 180)cool

write(nout, 190)nlitl

120 format(20a4)

130 format $(4 x, 12)$

140 format $(5 x, j 2)$

150 format $(5 x, f 8.1)$

160 format $(6 x, f 6.4)$

170 format $(5 x, i 2)$

180 format $(8 x, f 6.2)$

190 format $(8 x, i 2)$

c

c retrieve number densities from sas2h output (n71) for burn call density

c write(nout, 110 ) (iddk(i), $\operatorname{addk}(i), j=1, i$ tot)

c 110 format $(4(i 8,2 x, 1 p, e 10.4))$

c

c if the requested burnup or cooling time is 0 , it is not necessary

c to perform the origen-s step if(burn.eq.0.0.0r.cool.eq.0.0)go to 1000

c set up origen-s run to decay isotopics for requested cool time call tymstp(ncool, tstep) write(nout, 100)ncool

100 format ( $1 * * * *$ needed for phase 3 input**** ncool $=1, i 2,1.1)$ call litel(O)

call wrtors(tstep) go to 2000

c $* * * * \star * * * * *$ check file nout for messages

1000 continue

ncool $=0$

call rdinpt3(ncool)

call litel(0)

call clect(1)

call wrtice

c write number densities for mixing in keno to ... nout3 call wrtkeno

2000 stop end

c

c read input data for phase one calculations, reading sas $2 h$ output c and setting up origen-s decay only case 
subroutine rdinpt 1

common /const/ bconv, burn, cool, mixf, idmod, smacto

common /index/ nburn, ncrit, nlitl, ile, jact, ifp, i tot, ncyc

cormon /untnos/ n72, nout, n71, nors, nice

common /ident/ idlitl(40), iderit (200), iddk(2000)

common /adens/ adlitl (40), ltyp(40), adcrit $(200)$, addk (2000)

common /title/ ittl( 20$)$

character*6 ichk

$n 5=5$

read $(n 5,110)$ ichk

c read and check if appropriate phase input - snikr1

if (ichk.ne. 'snikr'') stop 5101

c read title card

read(n5, 120) ittl

c read label and check to be sure burn data is next read $(n 5,110)$ ichk

if (ichk.ne. 'read b')stop 5102

c read $n 72$, unit number for sas $2 h$ file 72 output to be read from $\operatorname{read}(n 5,130) n 72$

c read nout, unit number for output to be written to $\operatorname{read}(n 5,140)$ nout

c read burnup in mwd/mtu that number densities are to be retrieved from $n 72$ read(n5, 150)burn

c read metal (mtu/assembly), bconv is conversion factor for burnups

read from $n 72$

read(n5, 160)bconv

**** modified snikr, now read from sas $2 h$ output

read ncyc, number of burn cycles used to produce sas $2 h$ output on $n 72$ read(n5, 170)ncyc

c read and check that this is end of burnup data read $(n 5,110)$ ichk

if (ichk.ne.' end bu') stop 5103

c read and check that decay data begins with next card read(n5, 110) ichk

if (ichk.ne. 'read d')stop 5104

c read nors, unit number for origen-s input to be written $\operatorname{read}(n 5,140)$ nors

c read $n 71$, unit number for origen-s output to be written for phase 3 read(n5, 130)n71

c read cooling time in years to be used to set up origen-s decay case $\operatorname{read}(n 5,180) \mathrm{cool}$

c read the number of light elements to be specified in the decay case read(n5, 190)nlitl

c read and check that this is the end of decay data read(n5, 110) ichk

if(ichk.ne.'end de') st op 5105

c if nlitl is greater than zero read in id's of light elements if(nlitl.eq. 0$)$ go to 1000 read( $\left.n 5,{ }^{*}\right)$ (idl itl(i), adlitl(i), ltyp(i), $\left.i=1, n l i t l\right)$

1000 cont inue

c

write input to nout

write(nout, 120)ittl

write(nout, 130)n 72

write(nout, 140)nout

write(nout, 150)burn

write(nout, 160) bconv

write(nout, 170)ncyc

write(nout, 140)nors

write(nout, 180) cool

write(nout, 190)nlitl return

110 format (a6)

120 format (20a4)

130 format $(4 x, i 2)$ 


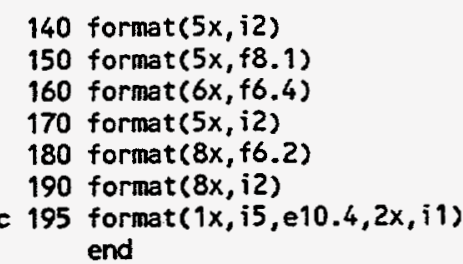

c

c returns iddk and addk arrays for the appropriate burnup, burn

c

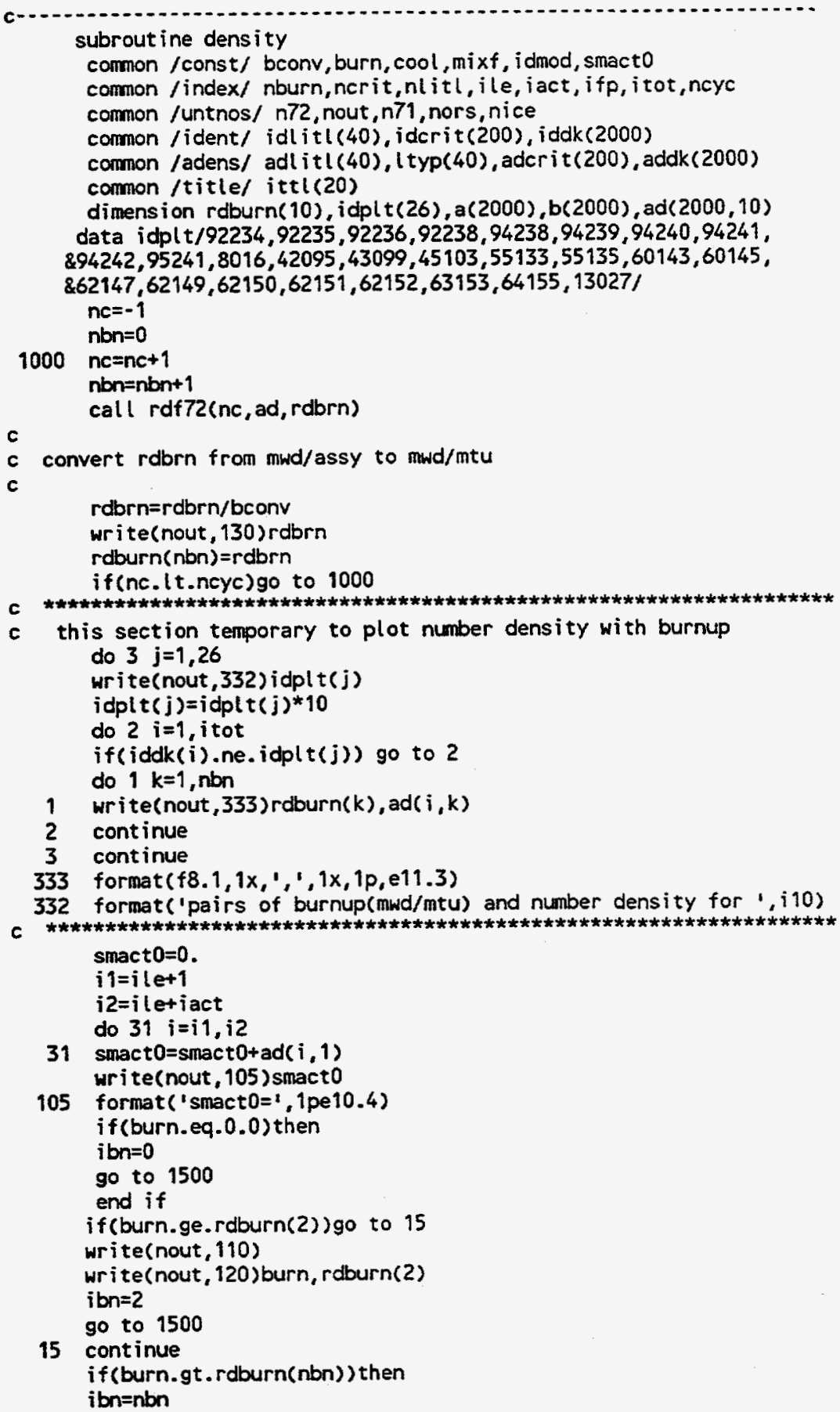


write(nout, 110)

write(nout, 140) burn, rdburn(nbn)

go to 1500

end if

do $20 i=1$, nbn

bdif $f=a b s$ ( $r d$ burn( $i$ ) - burn)/burn

if(bdiff. 1 t. 0.01$)$ then

$i b n=i$

go to 1500

end if

if(rdburn(i).gt.burn)go to 1250

i low $=$ i

20 cont inue

1250 cont inue

ih $\mathrm{i}=\mathrm{i}$ low+1

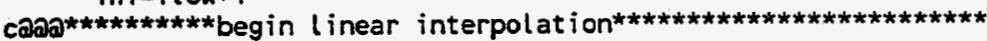

c do $25 k=1$, itot

c $\quad a(k)=\operatorname{ad}(k, i l o w)$

c $25 b(k)=a d(k$, ihi $)$

c call interp $(a, b$, rdburn(ilow), rdburn(ihi) $)$

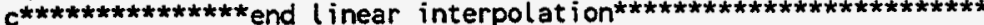

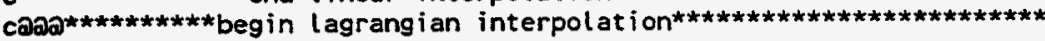

do $27 \mathrm{i=1}$, itot

do $26 \mathrm{j}=2, \mathrm{nbn}$

$26 a(j-1)=a d(i, j)$

do $28 k=2, n b n$

$28 b(k-1)=\operatorname{rdburn}(k)$

nbint=nbn-1

call lagint (b,a, nbint, burn, conc)

$27 \operatorname{addk}(i)=$ conc

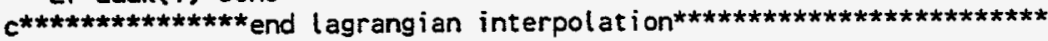
return

1500 continue

c write(nout, 160)

c write(nout, 150)(iddk(i), ad( $i, i b n), i=1, i$ tot)

do $30 j=1$, i tot

$30 \operatorname{addk}(j)=\operatorname{ad}(j, i b n)$

c write(nout, 150)(iddk(i), addk(i), $i=1, i$ tot) return

110 format('\$\$warning........-1$)$

120 format ('requested burnup of $1, f 10.3,1 \mathrm{gwd} / \mathrm{mtu}$ is less than first"

$\& /$ 'cycle burnup of $1, f 10.3,1$. first cycle burnup has been used')

130 format (' $r$ dbrn $=1, f 10.3$ )

140 format ('requested burnup of $1, f 10.3, '$ gwd/mtu is greater than last \&./'cycle burnup of ',f10.3,'. final cycle burnup has been used')

c 150 format $(4(i 8,2 x, 1 p, e 10.4))$

c 160 format ('past $1500^{\prime}$ ') end

subroutine rdf 72 (nc, ad, rdburn)

comon /const/ bconv, burn, cool, mixf, idmod, smact 0

comon /index/ nburn, nerit, nlitl, ile, iact, ifp, itot, ncyc

common /untnos/ n72, nout, n71, nors, nice

common /ident/ idlitl $(40)$, idcrit $(200)$, iddk(2000)

comon /adens/ adt itl(40), $(\operatorname{typ}(40)$, adcrit (200), addk (2000)

common /title/ ittl(20)

dimension $\operatorname{ad}(2000,10)$

character $* 4$ itest, $t t 172(20)$

nct $=$ nct +1

ind $=3$

c

read the following quantities from file 72 in addition to nuclide id and number density

1) Lpass, library pass no. used for origen-s case

2) mtime, position no. of data from unit no. 71

3) tw, time from start of assembly burnup, $d$

4) dum?

5) rdburn, accumulated burnup at tw, mwd/assembly 


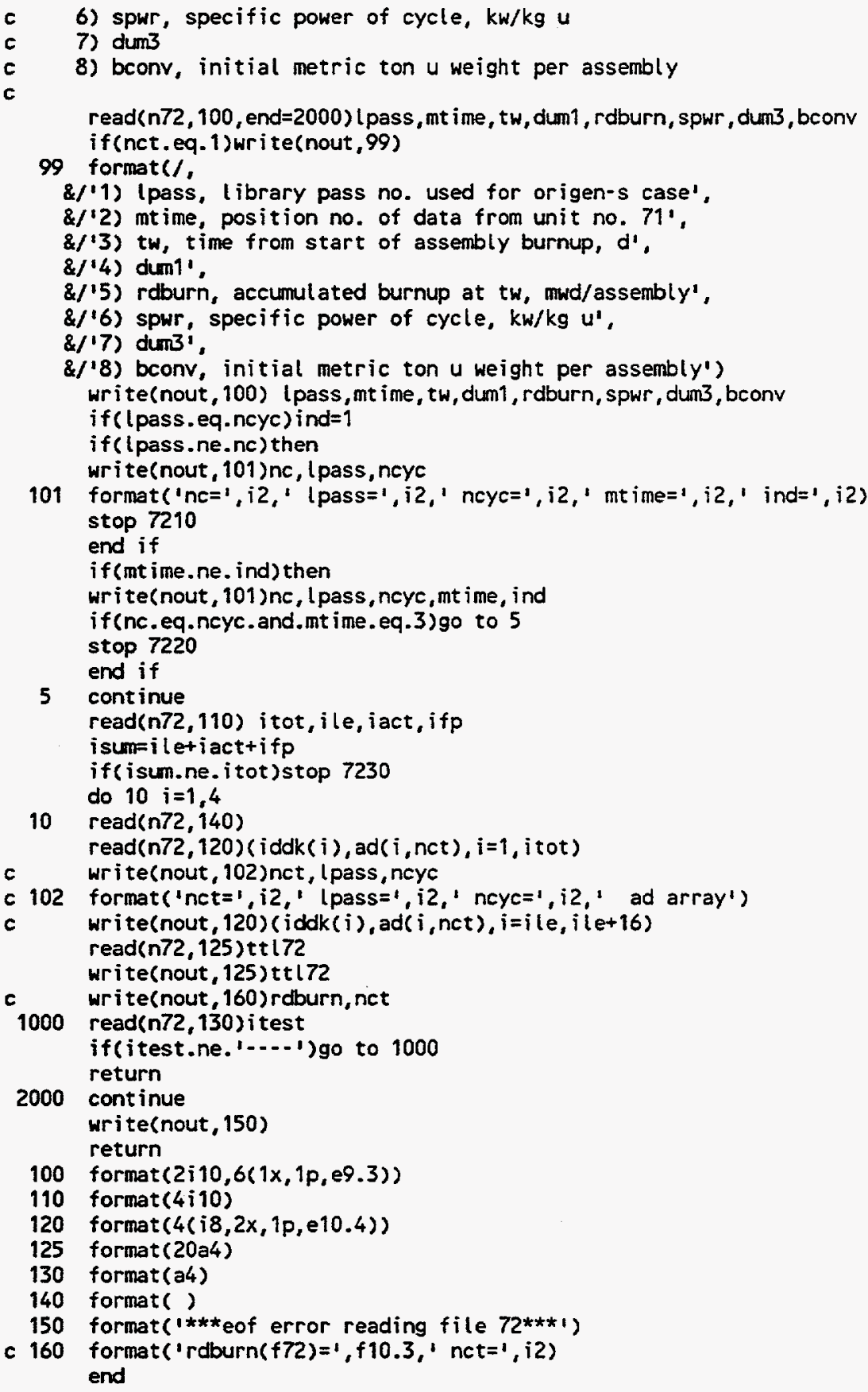

subroutine lagint $(x, y, n, x$ int, yout)

c this subroutine performs lagrangian interpolation within a set of

c $(x, y)$ pairs to give the $y$ value corresponding to $x$ int. the degree of

c the interpolating polynomial is one less than the number of points

c supplied. taken from gerald's "applied numerical analysis" pg 181

c parameters are:

$c \quad x$ - array of values of the independent variable

c $y$ - array of function values corresponding to $x$

c $n$ - number of points

c xint - the $x$-value for which estimate of $y$ is desired

c yout - the $y$-value returned to caller

dimension $x(10), y(10)$ 


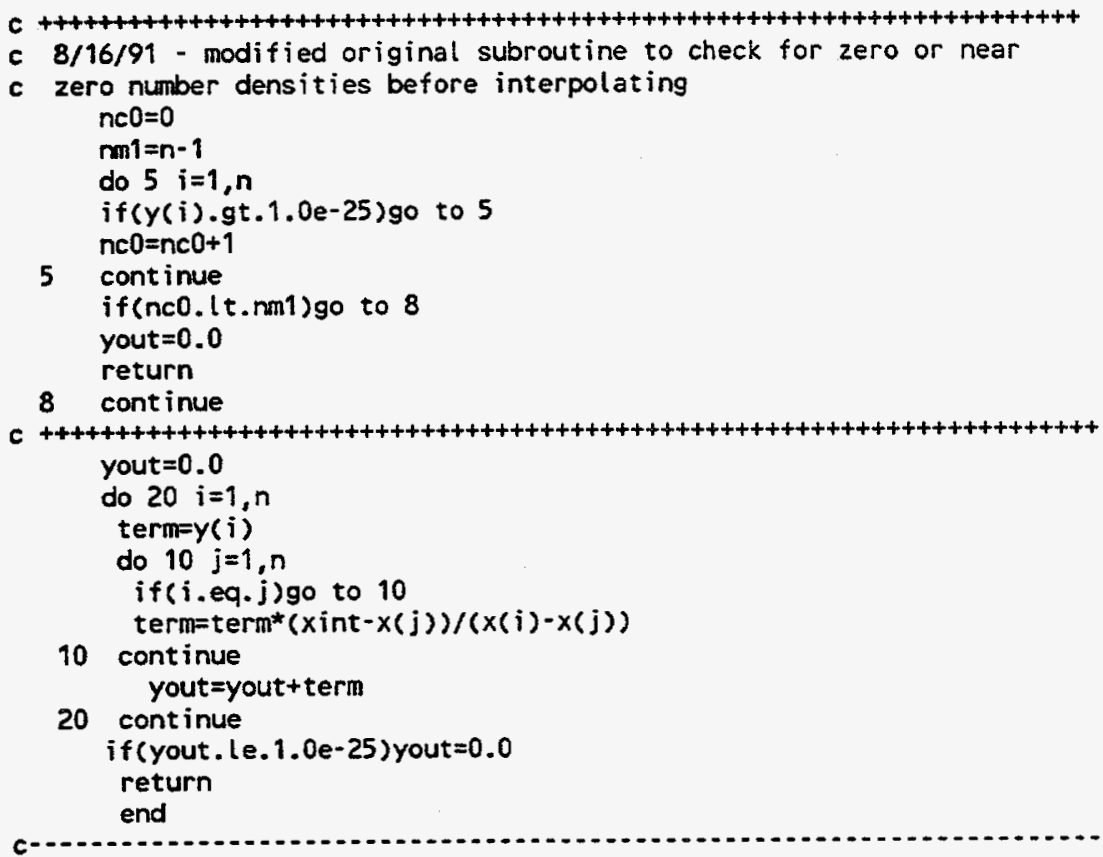

subrout ine interp $(a 1, a 2, b 1, b 2)$

c

c this routine linearly interpolates atom density as a

c function of burnup

c

cormon /const/ bconv, burn, cool, mixf, idmod, smacto

common /index/ nburn, ncrit, nlitl, ile, iact, ifp, itot, ncyc

common /untnos/ $\mathrm{n} 72$, nout, $n 71$, nors, nice

comon /ident/ idl itl(40), iderit (200), iddk(2000)

common /adens; adl itl(40), I typ (40), adcrit $(200)$, addk $(2000)$

common /title/ ittl( 20$)$

dimension al $(2000)$, a2 2000$)$

$\mathrm{db}=\mathrm{b} 2-\mathrm{b} 1$

del $b=b 2$-burn

do $10 i=1$, itot

slope $=(a 2(i)-a 1(i)) / d b$

addk $(i)=a 2(i)-s$ lope*delb

if(addk(i).lt.0.0)stop 7299

if (iddk(i).ne.922350)go to 10

write(nout, 111)b1,a1(i), b2,a2(i), slope, delb

write(nout, 112)addk(i)

10 cont inue

111 format $\left(' b 1=1, f 8.1, a_{1}=1, e 11.4,{ }^{\prime} b 2=1, f 8.1,1, a 2=1, e 11.4\right.$,

\&' slope=', e11.4,' delb=1,e11.4)

112 format('value for (inear interp for 92235 ', 1x, e11.4)

return

end

subrout ine tymstp(ncool, tstep)

common /const/ bconv, burn, cool, mixf, idmod, smacto

common /index/ nburn, nerit,nlitl, ile, iact, ifp, i tot, ncyc

common /untnos/ n72, nout, n71, nors, nice

common /ident/ idl it l(40), idcrit(200), iddk(2000)

cormon /adens/ adlitl $(40), l \operatorname{typ}(40)$, adcrit $(200), \operatorname{addk}(2000)$

common /title/ ittl( 20$)$

dimension tstep (10)

c

c this routine will check requested cooling time against the

c default tstep array and make any changes that are necessary

to accomodate the user's request 
if the user request a decay step not in the defaut $t$ ist

$c$ the time step nearest the requested cooling time will be

c altered. the longest cooling time allowed is 20 years.

$\operatorname{cootm} x=20$

do $10 j=1,10$

if(cool.ne.tstep(i))go to 10

ncool $=\mathbf{i}$

return

10 continue

if (cool. le.coolmx)go to 20

write(nout, 100)cool, coolmx

stop 801

20 cont inue

do $30 \quad j=1,9$

if (tstep (j).lt.cool.and.cool. lt.tstep $(j+1)$ ) then

$\mathrm{jcool}=\mathrm{j}$

go to 40

end if

30 continue

tstep $(10)=\mathrm{cool}$

ncool $=10$

return

$40 \quad f 1=c o o l-t s t e p(j c o o l)$

f2=tstep $(\mathrm{jcool}+1)-\mathrm{cool}$

if $(f 1 . g t . f 2)$ jcool $=\mathrm{jcool}+1$

tstep $(j \mathrm{cool})=\mathrm{coOl}$

ncool $=\mathrm{jcOOl}$

return

100 format('requested cooling time ', $f 7.2$, ' larger than maximum of ', \& 4 . 1, 'years' end

subrout ine litel(iflag)

c this subroutine checks to see if any

c light elements are requested by the

c user, if oxygen is not explicitly

c requested it is added.

common /const/ bconv, burn, cool, mixf, idmod, smact 0

comon /index/ nburn, nerit, nlitl, ile, iact, ifp, itot, ncyc

common /untnos/ n72, nout, n71, nors, nice

common /ident/ idlitl(40), iderit(200), iddk (2000)

common /adens/ adlitl(40), ltyp(40), adcrit(200), addk(2000)

comon /title/ ittl(20)

if(nlitl.ne.0)go to 10

nlitl=1

idt it $(1)=8016$

l typ $(1)=1$

go to 30

10 continue

do $20 \mathrm{i}=1, \mathrm{nlitl}$

if(idtitl(i).eq.8016)go to 35

20 continue

nlit l=nlitl+1

idlitl(nlitl) $=8016$

ltyp(nlitl)=1

30 continue

if(iflag.eq.1)go to 45

adlit $l(n l i t l)=2.0^{*}$ smacto

write(nout, 110)adl itl (nl itl)

110 format('adlitl(nlit) $=1$, 1pe10.4?

35 continue

do $40 i=1, n$ ititl

do $40 j=1$, ile

$i d t=i d l i t(i) * 10$ 


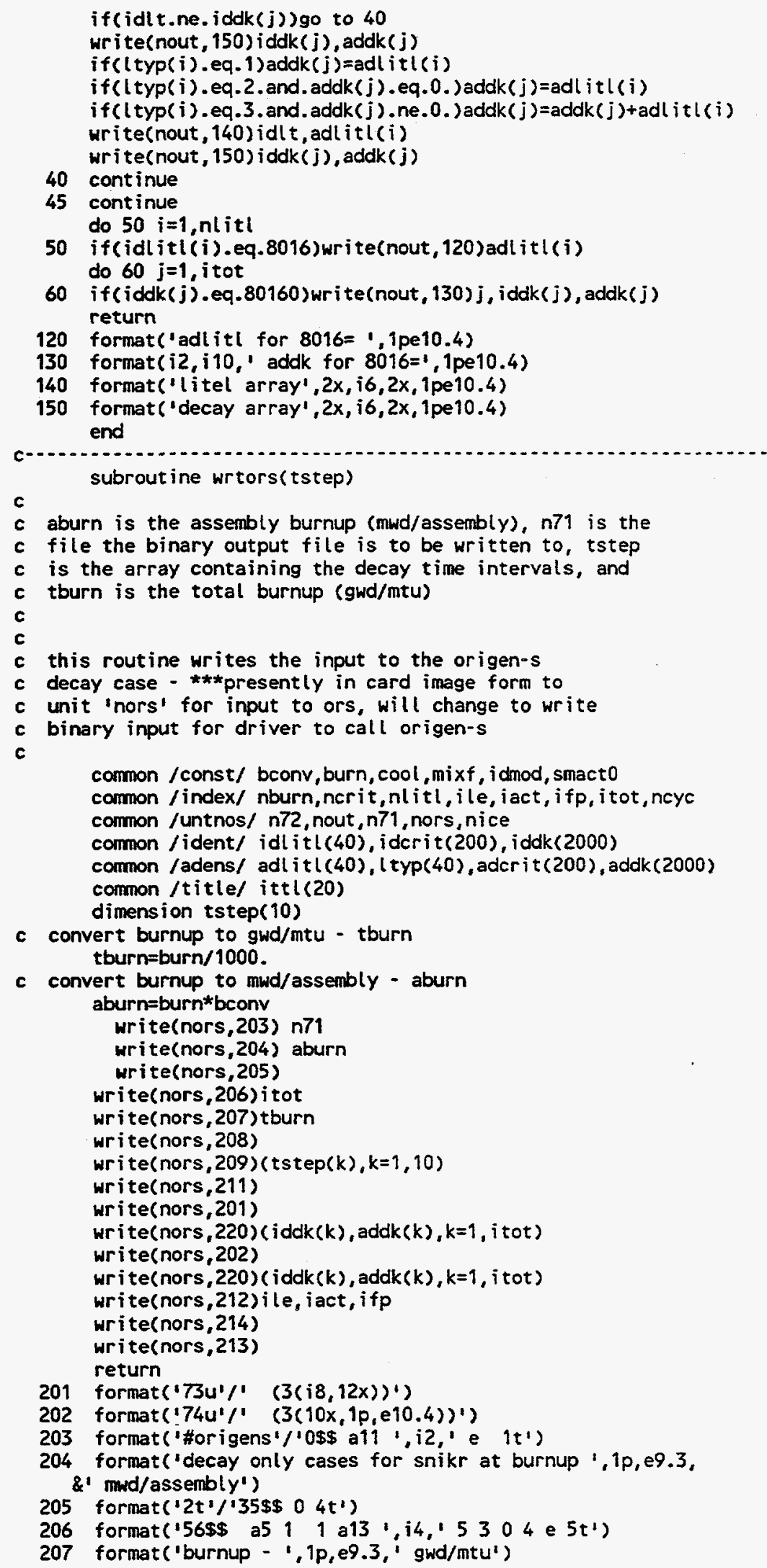



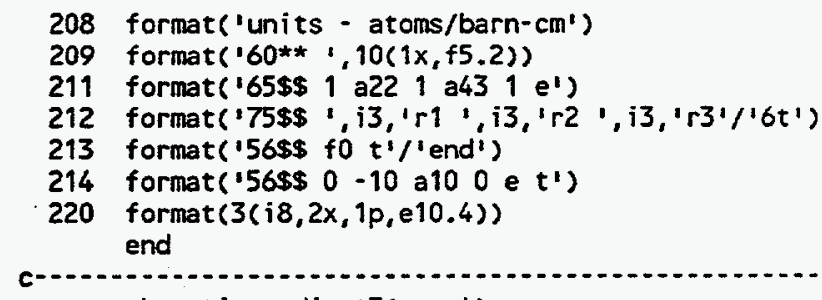

subrout ine rdinpt3(ncool)

common /const/ bconv, burn, cool, mixf, idmod, smacto

common /index/ nburn, nerit, nlitl, ile, iact, ifp, itot, ncyc

common /untnos/ n72, nout, n71, nors, nice

comon /ident/ idlitl(40), idcrit (210), iddk(2000)

common /adens/ adlitl(40), $l \operatorname{typ}(40)$, adcrit $(200)$, addk $(2000)$

common /title/ ittl(20)

character*6 ichk

dimension idat1(25), idat2(37), idat3(49), idat4(193)

data idat1/92234,92235,92236,92238,94238,94239,94240,94241,

$894242,95241,8016,42095,43099,45103,55133,55135,60143,60145$,

$862147,62149,62150,62151,62152,63153,64155 /$

data idat2/92234,92235,92236,92238,93237,94238,94239,94240,94241. $894242,95241,95243,96244,8016,40093,42095,43099,44101,45103,46105$, $846108,47109,55133,55135,59141,60143,60145,61147,62147,62149$, $\& 62150,62151,62152,63153,63154,63155,64155 /$

data idat $3 / 92234,92235,92236,92238,93237,94238,94239,94240,94241$, $894242,95241,95243,96244,8016,36083,40093,42095,43099$,

$844101,44103,45103,45105,46105,46108,47109,53135,54131,54135$,

$855133,55134,55135,59141,60143,60145,60147,60148,61147,61148$, $861149,62147,62149,62150,62151,62152,63153,63154,63155,64155$, $\$ 99999 /$

data idat $4 / 32072,32073,32074,32076,33075,34076,34077,34078,34080$, $834082,35079,35081,36080,36082,36083,36084,36085,36086,37085,37086$, $837087,38086,38087,38088,38089,38090,39089,39090,39091,40090,40091$, $840092,40093,40094,40095,40096,41093,41094,41095,8016,42095,42096$, $842097,42098,42099,42100,43099,44099,44100,44101,44102,44104,44105$, $844106,46104,46105,46106,46107,46108,46110,47107,47109,47111,48108$, $848110,48111,48112,48113,48114, \quad 48116,49113,49115,50115,50116$. $850117,50118,50119,50120,50122,50123,50124,50125,50126,51121,51123$, $851124,51125,51126,52122,52123,52124,52125,52126, \quad 52128$,

$852130,52132,53127,53129,53130,53131,54128,54129,54130,54131,54132$, $854133,54134,54136,55133,55134,55135,55136,55137,56134,56135,56136$, $\& 56137,56138,56140,57139,57140,58140,58141,58142,58143,58144,59141$, $859142,59143,60142,60143,60144,60145,60146,60150,61151,62147,62148$, $862150,62151,62152,62153,62154,63151,63152,63156,63157,64154,64156$, $864157,64158,64160,65159,65160,66160,66161,66162,66163,66164,67165$. $\$ 68166,68167,44103,45103,45105,53135,54135,60147,60148,61147,61148$, $862149,61149,63153,63154,63155, \quad 64155,90232,91233,92233,92234$, $892235,92236,92238,93237,94238,94239,94240,94241,94242,95241$, 895243,962441

$n 5=5$ read(n5, 110)ichk

c read and check if appropriate phase input - snikr3

if (ichk.ne.'snikr3')stop 5301

c read title card read(n5, 120)ittl

c read label and check to be sure mxfuel data is next $\operatorname{read}(n 5,110)$ ichk

if (ichk.ne. 'read $\mathrm{m}$ ') stop 5302

c read $n 72$, unit number for origen-s file 71 output to be read from read( $n 5,130) n 71$

c read nice, unit number for ice input to be written to read(n5, 140)nice

c read nout, unit number for output to be written to read( $n 5,140)$ nout

c read ncool, number of cooling step for which densities are to be read if (ncool .gt . 0) read $(n 5,110)$

if (ncool.eq. 0$)$ read $(n 5,145)$ ncool 
c read flag nf is to determine which fuel nuclides will be used in

c keno calculations:

c $\quad=0$ use ttc713 intersection with sid bierman's nucs

c $\quad=-1$ use ttc713

c $\quad=-2$ use ttc713 u sid u vepco u casmo

c $\quad=-3$ use all 27burnuplib nuclides

c $\quad=n$ read in user's choice of nuclides

read(n5, 150)nfis

if (nf is.eq. 0 ) then

nerit $=25$

do $10 \quad i=1$, nerit

10 iderit(i)=idat1(i)

go to 500

end if

if (nf is.eq. -1$)$ then

nerit $=37$

do $20 i=1$, nerit

20 idcrit(i)=idat2(i)

go to 500

end if

if (nf is.eq. -2 ) then

nerit $=49$

do 21 i=1,ncrit

21 idcrit(i)=idat3(i)

go to 500

end if

if (nf is.eq. -3 ) then

nerit $=193$

do $31 i=1$, nerit

31 iderit(i)=idat4(i)

go to 500

end if

if (nfis.gt.0)ncrit=nfis

500 cont inue

c read mixture number to be used for fuel of this burn in keno calculations read( $n 5,160) \mathrm{mixf}$

c read integer modifier for fuel nuclide id's for use in ice run $\operatorname{read}(n 5,145)$ idmod

c read and check that this is end of fuel mix data read $(n 5,110)$ ichk

if (ichk.ne. 'end $m x^{2}$ )stop 5303

c if fisprod is greater than zero read in id's of elements in fuel for

c criticality calculations

if (nfis.le.0)go to 1000

$\operatorname{read}(n 5,170)(i d c r i t(i), i=1, n c r i t)$

1000 continue

c

c write input to nout

write(nout, 120) ittl

write(nout, 130 )n71

write(nout, 140)nice

write(nout, 140)nout

write(nout, 145)ncool

write(nout, 150 ) nf is

write(nout, 160)mixf

write(nout, 145) idmod

write(nout, 170)(iderit(i), $i=1$, nerit)

110 format (a6)

120 format (20a4)

130 format $(4 x, i 2)$

140 format $(5 x, i 2)$

145 format $(6 x, i 2)$

150 format $(8 x, i 3)$

160 format $(5 x, 14)$

170 format $(10(1 x, i 5))$

return

end 


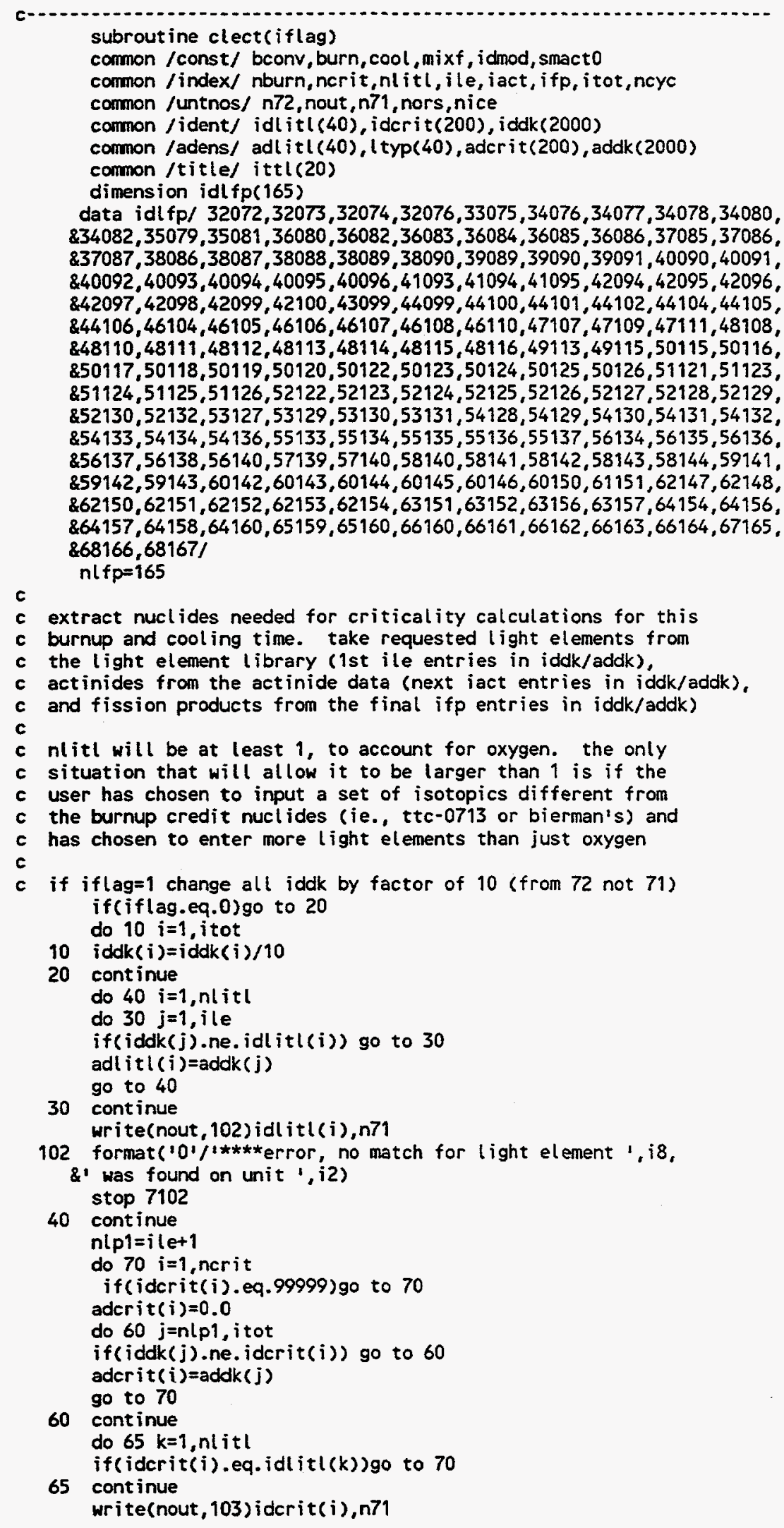


103 format( $101 / 1 * * * *$ error, no match for nuclide ', i8,

\&' was found on unit 1, i2)

stop 7103

70 continue

c add contribution from light element and actinide/fission product libr do $80 \mathrm{i=1,nlitl}$

do $80 j=1$,ncrit

if(idcrit(j).ne.idlitl(i))go to 80

adcrit $(j)=\operatorname{adcrit}(j)+\operatorname{adl} i t(i)$

80 continue

c compute number density for lumped-fission product if requested

c only available for nfis=-2 (for mikey's use only)***

adt $f p=0.0$

if $0=i$ le + iact

c do we need to calculate a lumped fission product

c check to see if idcrit $=99999$, if so calculate $1 \mathrm{fp}$

c also (if ickfp=1) check to see if any nuclide in idcrit is also

c in idlfp, if so set idlfp to zero

c ickfp=0 will calculate the virginia power lumped fission product

c explicitly ickfp=0

c ickfp=1 calculates vp lfp minus $f p$ in idcrit array \#don't use now

c ickfp=1

$k 99=0$

do $92 k l=1$, ncrit

if(iderit(kl).eq. 99999$) k 99=k$ l

if (ickfp.eq.0)go to 92

do $90 j=1, n l f p$

if(idlfp $(j)$.ne.iderit(kl))go to 90

write(nout, 110 )idlfp(j)

id $f p(j)=0$

go to 92

90 continue

92 continue

110 format (i10,' nuclide was in idlfp and idcrit')

c no Ifp calculation is required if $k 99=0$

if ( $k 99$. eq. 0 ) return

do $95 \mathrm{i}=1$, ifp

$j=i f p 0+i$

do $94 k j=1, n l f p$

if(iddk(j).ne.idlfp(kj))go to 94

adl $f p=a d t ~ f p+\operatorname{addk}(j)$

go to 95

94 continue

95 continue

adcrit $(k 99)=$ adl fp

return

end

c

$c$

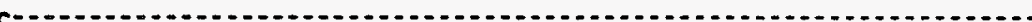

subroutine wrtice

common /const/ bconv, burn, cool, mixf, idmod, smacto

common /index/ nburn, ncrit, nlitl, ile, iact, ifp, itot, ncyc

common /untnos/ n72, nout, n71, nors, nice

common /ident/ idlitl(40), idcrit (200), iddk(2000)

common /adens/ adlitl(40), (typ(40), adcrit(200), addk(2000)

comnon /title/ ittl(20)

dimension $i 2(200), i 5(200), i 11(201), i d a c t(7)$

character ${ }^{*} 4$ dum, $t$, ice, end

data idact $/ 92234,92235,92236,92238,94239,94240,94241 /$

$t=1 \quad t$

ice $=$ '\#ice'

end $=$ 'end' 
$\operatorname{mix}=1$

write(nice, 110) ice

write(nice, 110)ittl

110 format(2024)

dum $=11 \$ \$$,

write(nice, 110) dum

$\mathrm{i} i=0$

$14=10$

kopt $=4$

write(nice, 120)mix, ncrit, ii, ii, ii , i4, kopt

120 format( $6 i 12)$

write(nice, 110)t

do $10 i=1$, nerit

$10 \quad i 2(i)=1$

dum $=12 \$ \$$.

write(nice, 110)dum

write(nice, 120)( $i 2(i), i=1$, nerit)

if (idnod.eq.0)go to 35

do $30 j=1,7$

do $30 i=1$, nerit

if(iderit(i).ne. idact(j))go to 30

30 continue

35 continue

c

dum a '3\$\$!

write(nice, 110)dum

write(nice, 120)(iderit(i), i=1, nerit)

c

dum $\square 14$ **

write(nice, 110)dum

write(nice, 130)(aderit(i), $i=1$, ncrit)

130

format $(1 p, 6 e 12.4)$

$i 5(1)=4$

dum $=15 \$ \$$,

write(nice, 110)dum

write(nice, 120) (i5 (i) , $j=1$, mix $)$

write(nice, 110)t

$c$

dum= $17 \$ \$$

write(nice, 110) dum

write(nice, 140)

write(nice, 110)t

140 format(' a8 2 e')

c

$i 11(1)=1$

i11(2)=mixf

dum $=111 \$ s:$

write(nice, 110)dum

write(nice, 120)(i11(i), $i=1$, mix +1$)$

write(nice, 110)t

write(nice, 110)end

c

return

end

subroutine wrtkeno

cormon /const/ bconv, burn, cool, mixf, idmod, smacto

common /index/ nburn, ncrit, nlitl, ile, iact, ifp, itot, ncyc

common /untnos/ n72, nout, n71, nors, nice

common /ident/ idlitl(40), idcrit(200), iddk(2000)

cormon /adens/ adlitl(40), ltyp(40), adcrit $(200)$, addk(2000) 


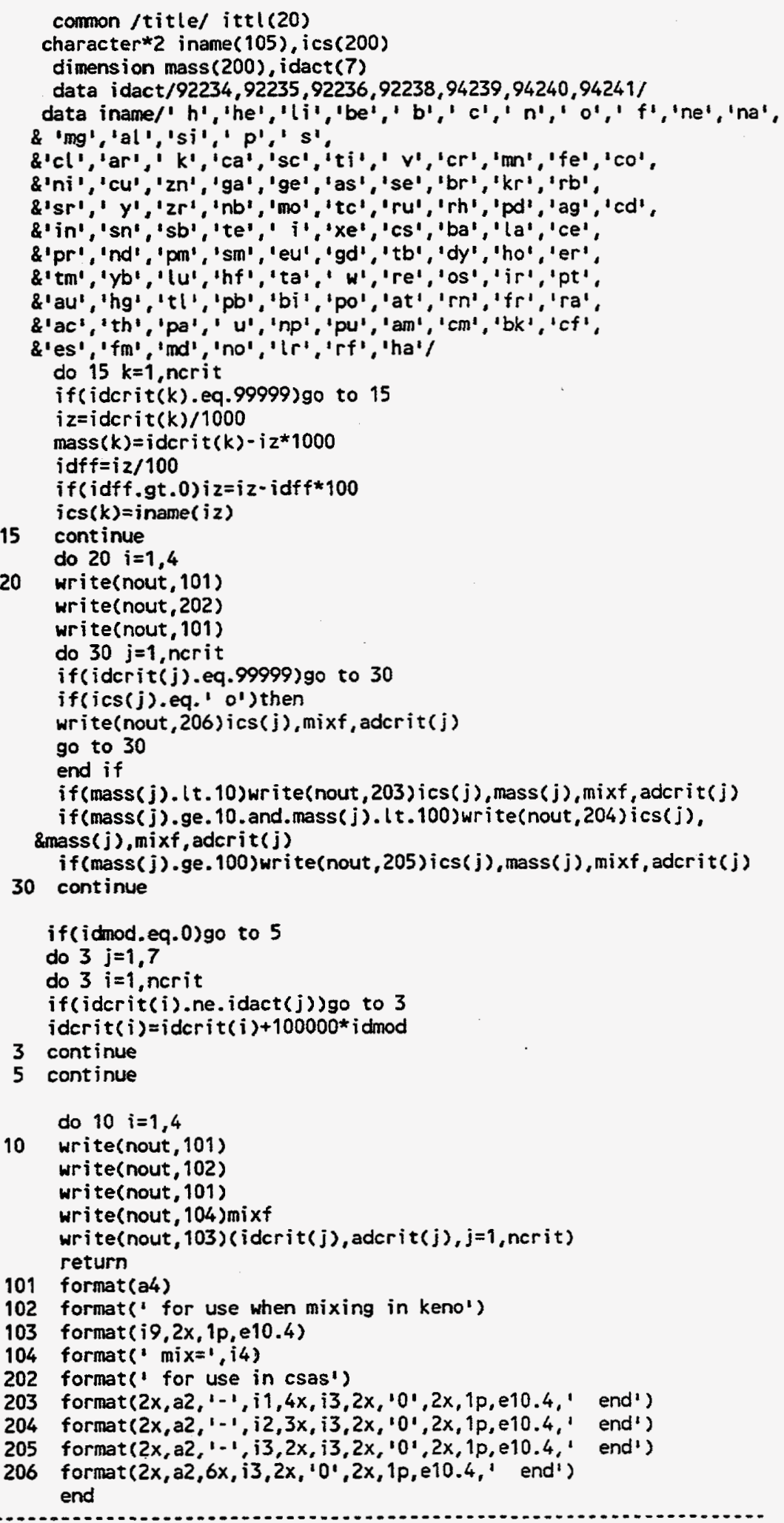




\section{C.3 SNIKR3 FORTRAN LISTING}

c

program snikr3

comon /const/ beonv, burn, cool, mixf, idmod, smacto

common /index/ nburn, nerit, nlitl, ile, iact, ifp, itot, ncyc

comon /untnos/ n72, nout, n71, nors, nice

common /ident/ idlitl(40), iderit (210), iddk(2000)

common /adens/ adlitl(40), ltyp(40), aderit (200), addk (2000)

cormon /title/ ittl(20)

dimension tym(20)

c read snikr1 input again

call rdinpt 1

c read input to snikr needed to set up ice run

ncool $=0$

catl rdinpt3 (ncool)

c retrieve number densities at cooltime for nuclides to be used in

c criticality analyses

nnct $=0$

nncl $=1$

if (ncool.lt.0) then

ncool $=0$

nncl $=11$

end if

1000 continue

nnct $=$ nnct +1

npos=ncool + nnet

call $\operatorname{rdf} 71$ (npos, tym)

rewind $n 71$

call litel(1)

call clect $(0)$

c set up ice run to create mixture cross sections for keno calcs

c first remove any nuclides with number densities less than 1e-24

write(nout, 107) npos

write(nout, 108)tym(npos)

write(nice, 107) npos

write(nice, 108) tym(npos)

call wrtice

c use mixed cross sections written on unit nice in keno calc

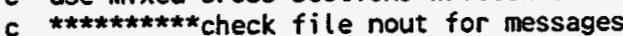

c write number densities for mixing in keno to ...nout3

107 format ('isotopic results for cool step ', i2)

108 format ('origens cooling time $(y r)=1, f 6.2$ )

call wrtkeno

if (nnct.lt.nncl)go to 1000

stop

end

$c$

c read input data for phase one calculations, reading sas2h output

$c$ and setting up origen-s decay only case

subrout ine rdinpt 1

common /const/ bconv, burn, cool, mixf, idmod, smacto

common /index/ nburn, ncrit, nlitl, ile, iact, ifp, i tot, ncyc

common /untnos/ $n 72$, nout, n71, nors, nice

common /ident/ idititl(40), idcrit(210), iddk(2000)

comnon /adens/ adtitl(40), ltyp(40), adcrit $(200)$, addk(2000)

common /title/ ittl(20)

character $* 6$ ichk

$n 5=5$

read(n5, 110) ichk

c read and check if appropriate phase input - snikr1

if (ichk.ne. 'snikr ' ') stop 5101

c read title card

read $(n 5,120)$ ittl 
c read label and check to be sure burn data is next read(n5, 110)ichk

if (ichk.ne. 'read b') stop 5102

c read $n 72$, unit number for sas $2 h$ file 72 output to be read from $\operatorname{read}(n 5,130) n 72$

c read nout, unit number for output to be written to read( $n 5,140)$ nout

c read burnup in mwd/mtu that number densities are to be retrieved from $n 72$ read $(n 5,150)$ burn

c read metal (mtu/assembly), bconv is conversion factor for burnups

read from $n 72$

read(n5, 160)bconv

**** modified snikr, now read from sas $2 h$ output

read ncyc, number of burn cycles used to produce sas $2 \mathrm{~h}$ output on $n 72$ read(n5, 170)ncyc

c read and check that this is end of burnup data read( $n 5,110)$ ichk

if (ichk.ne. 'end bu') stop 5103

c read and check that decay data begins with next card read(n5, 110)ichk

if (ichk.ne. 'read d') stop 5104

c read nors, unit number for origen-s input to be written read $(n 5,140)$ nors

c read $n 71$, unit number for origen-s input to be written for phase 3 $\operatorname{read}(n 5,130) n 71$

c read cooling time in years to be used to set up origen-s decay case read $(n 5,180)$ cool

c read the number of light elements to be specified in the decay case read(ns, 190)nlitl

c read and check that this is the end of decay data read( $n 5,110)$ ichk

if (ichk.ne.' 'end de')stop 5105

c if nlitl is greater than zero read in id's of light elements if (nlitl.eq.0)go to 1000 read(n5,195)(idlitl(i), adlitl(i), (typ(i), i=1, nlitl)

1000 continue

write input to nout

write(nout, 120) ittl

write(nout, 130)n72

write(nout, 140)nout

write(nout, 150) burn

write(nout, 160) bconv

write(nout, 170)ncye

write(nout, 140) nors

write(nout, 180) cool

write(nout, 190)nlitl

return

110 format (a6)

120 format (20a4)

130 format $(4 x, 12)$

140 format $(5 x, 12)$

150 format $(5 x, f 8.1)$

160 format $(6 x, f 6.4)$

170 format $(5 x, i 2)$

180 format $(8 x, f 6.2)$

190 format $(8 x, i 2)$

195 format ( $1 x, i 5,1 p, e 10.4,0 p, 2 x, i 1)$

end

c

c

subrout ine rdinpt3 (ncool)

common /const/ bconv, burn, cool, mixf, idmod, smacto

common /index/ nburn, ncrit, nlitl, ile, iact, ifp, itot, ncyc

common /untnos/n72, nout, n71, nors, nice 
common /ident/ idlitl(40), idcrit(210), iddk(2000)

common /adens/ adtitl(40), l typ(40), adcrit(200), addk (2000)

common /title/ ittl(20)

character*6 ichk

dimension idat $1(25)$, idat2(37), idat3(49), idat4(193)

data idat1/92234,92235,92236,92238,94238,94239,94240,94241,

$894242,95241,8016,42095,43099,45103,55133,55135,60143,60145$,

$\& 62147,62149,62150,62151,62152,63153,64155 /$

data idat2/92234,92235,92236,92238,93237,94238,94239,94240,94241. $\& 94242,95241,95243,96244,8016,40093,42095,43099,44101,45103,46105$, $246108,47109,55133,55135,59141,60143,60145,61147,62147,62149$, $\$ 62150,62151,62152,63153,63154,63155,64155 /$

data idat3/92234,92235,92236,92238,93237,94238,94239,94240,94241, $894242,95241,95243,96244,8016,36083,40093,42095,43099$,

$\$ 44101,44103,45103,45105,46105,46108,47109,53135,54131,54135$,

$855133,55134,55135,59141,60143,60145,60147,60148,61147,61148$, $861149,62147,62149,62150,62151,62152,63153,63154,63155,64155$, 8999991

data idat4/ 32072,32073, 32074,32076, 33075, 34076,34077, 34078, 34080, $\& 34082,35079,35081,36080,36082,36083,36084,36085,36086,37085,37086$, $837087,38086,38087,38088,38089,38090,39089,39090,39091,40090,40091$, $840092,40093,40094,40095,40096,41093,41094,41095,8016,42095,42096$, $842097,42098,42099,42100,43099,44099,44100,44101,44102,44104,44105$, $844106,46104,46105,46106,46107,46108,46110,47107,47109,47111,48108$, $848110,48111,48112,48113,48114, \quad \quad 48116,49113,49115,50115,50116$, $850117,50118,50119,50120,50122,50123,50124,50125,50126,51121,51123$, $\& 51124,51125,51126,52122,52123,52124,52125,52126, \quad 52128$, $852130,52132,53127,53129,53130,53131,54128,54129,54130,54131,54132$, $\& 54133,54134,54136,55133,55134,55135,55136,55137,56134,56135,56136$, $\& 56137,56138,56140,57139,57140,58140,58141,58142,58143,58144,59141$, $859142,59143,60142,60143,60144,60145,60146,60150,61151,62147,62148$, $862150,62151,62152,62153,62154,63151,63152,63156,63157,64154,64156$, $864157,64158,64160,65159,65160,66160,66161,66162,66163,66164,67165$, $868166,68167,44103,45103,45105,53135,54135,60147,60148,61147,61148$, $\$ 62149,61149,63153,63154,63155, \quad 64155,90232,91233,92233,92234$, $892235,92236,92238,93237,94238,94239,94240,94241,94242,95241$, $\$ 95243,96244$ /

$\mathrm{n} 5=5$ read $(n 5,110)$ ichk

read and check if appropriate phase input - snikr3

if (ichk.ne.'snikr3') stop 5301

c read title card read $(n 5,120)$ ittl

c read label and check to be sure mxfuel data is next read $(n 5,110)$ ichk

if(ichk.ne. 'read $\mathrm{m}^{\mathrm{l}}$ ) stop 5302

read $n 72$, unit number for origen-s file 71 output to be read from read(n5, 130) n71

c read nice, unit number for ice input to be written to read( $n 5,140)$ nice

c read nout, unit number for output to be written to read $(n 5,140)$ nout

c read ncool, number of cooling step for which densities are to be read if (ncool.gt.0)read( $n 5,110)$

if (ncool. eq. 0 ) read( $n 5,145)$ ncool

c read flag nfis to determine which fuel nuclides will be used in

keno calculations:

$$
\begin{aligned}
& =0 \text { use ttc713 intersection with sid bierman's nucs } \\
& =-1 \text { use ttc713 } \\
& =-2 \text { use ttc713 u sid u vepco u casmo } \\
& =-3 \text { use all } 27 b u r n u p l i b \text { nuclides } \\
& =n \text { read in user's choice of nuclides }
\end{aligned}
$$

read $(n 5,150)$ nf is

if (nf is.eq. 0 ) then

ncrit $=25$

do $10 i=1$, nerit

10 iderit(i)=idat1(i)

go to 500 
end if

if (nf is.eq. - 1 ) then

nerit $=37$

do $20 \quad i=1$, ncrit

20 iderit(i)=idat2(i)

go to 500

end if

if (nf is. eq. -2 ) then

nerit $=49$

do $21 \mathrm{i}=1$, ncrit

21 iderit( $i)=i d a t 3(i)$

go to 500

end if

if (nf is.eq. -3 ) then

ncrit $=193$

do 31 i=1, nerit

31 idcrit(i)=idat4(i)

go to 500

end if

if (nfis.gt.0)nerit=nfis

500 continue

c read mixture number to be used for fuel of this burn in keno calculations read(n5, 160)mixf

c read integer modifier for fuel nuclide id's for use in ice run $\operatorname{read}(n 5,145)$ idmod

c read and check that this is end of fuel mix data read $(n 5,110)$ ichk

if (ichk.ne. 'end $m \times$ ') stop 5303

c if fisprod is greater than zero read in id's of elements in fuel for

c criticality calculations

if(nf is. le.0)go to 1000

read( $n 5,170)$ (iderit( $i), i=1$, nerit)

1000 cont inue

c write input to nout

c

write(nout, 120)ittl

write(nout, 130)n71

write(nout, 140)nice

write(nout, 140) nout

write(nout, 145) ncool

write(nout, 150)nf is

write(nout, 160)mixf

write(nout, 145) idmod

write(nout, 170)(iderit(i), $i=1$, ncrit)

110 format (a6)

120 format (20a4)

130 format $(4 x, i 2)$

140 format $(5 x, i 2)$

145 format $(6 x, i 2)$

150 format $(8 x, i 3)$

160 format $(5 x, i 4)$

170 format $(10(1 x, 55))$

return

end

subrout ine rdf71(npos, tym)

c

c this routine reads atom densities from the binary output

c file on unit ' $n 71$ ' written from origen-s for the decay time

c corresponding to the position, npos(equal to ncool +1 , where

c ncool is returned from subroutine tymstp), and at the

c requested burnup, burn.

c

common /const/ bconv, burn, cool, mixf, idmod, smacto

common /index/ nburn, ncrit, nlitl, ile, iact, ifp, itot, ncyc

common /untnos/ n72, nout, n71, nors, nice

common /ident/ idlitl(40), iderit(210), iddk(2000) 
common /adens/ adlitl(40), ltyp(40), adcrit(200), addk(2000)

common /title/ ittl( 20$)$

dimension tym(20)

c

c iddk and addk are arrays containing the id's and number densities for

c all nuclides used in the origen-s decay

c case. in this routine they are used to retrieve data from unit n71

c before it is condensed into the adcrit array which will contain number

c densities corresponding to the id's given in idcrit. idcrit contains

c ids for the nuclides to be used in the criticality analysis. the

c densities stored in adcrit are burnup dependent.

c

c files needed in this subroutine should be opened by the main program

10 read(n71, end $=100)$ i tot, i le, i act, ifp, nd1, nd2, nstep, \&n1,n2, n3, n4, n5, n6, n7, n8, n9, n10,n11,n12, n13,n14,n15,

\&n16, n17, n18, n19, n20, n21, n22, n23, r1, r2, r3, r4, tym(npos)

write(nout, 102) i tot, ile, iact, ifp, ns tep, tym(npos)

if (nstep.eq.npos) then

$\operatorname{read}(n 71$, end $=100)$ ( $i d d k(i), i=1, i$ tot $),(\operatorname{addk}(i), i=1, i$ tot $)$

do $15 i=1$, itot

c - added this line to eliminate double entries caused by metastable

c -- isotopes (e.g., gd-155m) when dividing by $10 \ldots$ smb $6 / 16 / 93$

15 if $(\bmod (i d d k(i), 10)$

ial $=i l e+1$

iaz=iletiact+ifp

write(nout, 103) (iddk( $i), \operatorname{addk}(i), j=i a 1, i a 2)$

go to 20

endif

read(n71, end $=100$ ) idumy

go to 10

100 write(nout, 101)n71

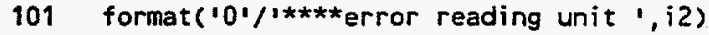

stop 7101

20 cont inue

102 format $(5(1 x, j 4), f 6.2)$

103 format $(4(i 8,2 x, 1 p, e 10.4))$

return

end

subroutine (itel(iflag)

c

c this subroutine checks to see if any

c light elements are requested by the

c user, if oxygen is not explicitly

c requested it is added.

common /const/ bconv, burn, cool, mixf, idmod, smact0

common /index/ nburn, nerit, nlitl, ile, iact, ifp, itot, ncyc

common /untnos/ $n 72$, nout, n71, nors, nice

common /ident/ idlit l(40), idcrit(210), idák (2000)

common /adens/ adlitl(40), I typ (40), adcrit(200), addk (2000)

common /title/ ittl(20)

iffentitl.ne.0)go to 10

$n l i t=1$

idl it $l(1)=8016$

ltyp $(1)=1$

c -- commented this out to get oxygen automatically added -- smb 6/16/93

c go to 30

10 continue

do $20 i=1, n l i t l$

if(idlitl(i).eq.8016)go to 35

20 continue

nlit $l=n !$ it $l+1$

idl it $l(\mathrm{nl}$ it $l)=8016$

ltyp(nlitl)=1 
30 continue

if (iflag.eq.1)go to 45

adl itl (nlitl) $=2.0 *$ smacto

write(nout, 110)adl itl(nlitl)

110 format ('adlitl(nlitl)=1,1pe10.4)

35 continue

do $40 \quad i=1, n t i t$

do $40 \mathrm{j}=1$, $i$ le

$i d t=i d t i t l(i) * 10$

if (idlt.ne.iddk(j)) 90 to 40

write(nout, 150) iddk ( $j$ ), addk ( $j$ )

if (ltyp(i).eq.1)addk $(j)=a d l i t l(i)$

if (ltyp(i).eq.2. and. $\operatorname{addk}(j) \cdot$ eq. 0.$) \operatorname{addk}(j)=\operatorname{adl} i$ t $(i)$

if $(t$ typ $(i)$.eq.3. and.addk $(j)$.ne.0. $\operatorname{addk}(j)=\operatorname{addk}(j)+\operatorname{adl} i t({ }(i)$

write(nout, 140)idlt, adlitl(i)

write(nout, 150) iddk $(j)$, addk ( $j)$

40 continue

45 continue

do $50 \mathrm{i}=1, \mathrm{nlit}$

50 if(idlitl(i).eq.8016)write(nout, 120)adlitl(i)

do $60 j=1$, $i$ tot

60 if(iddk(j).eq. 80160)write(nout, 130) j, iddk(j), addk (j)

return

120 format('adlitl for $8016=1,1$ pe10.4)

130 format $(i 2, i 10,1$ addk for $8016=1,1$ pe10.4)

140 format('litel array', 2x, i6, 2x, 1pe10.4)

150 format ('decay array', 2x, i6, 2x, 1pe10.4)

end

subroutine clect(iflag)

common /const/ beonv, burn, cool, mixf, idmod, smacto

cormon /index/ nburn, ncrit, nlitl, i le, iact, ifp, itot, ncyc

common /untnos/ n72, nout, n71, nors, nice

common /ident/ idtitl(40), idcrit(210), iddk(2000)

common /adens/ adlitl(40), ltyp(40), adcrit (200), addk (2000)

comon /title/ ittl(20)

dimension idlfp(165)

data idlfp/ $32072,32073,32074,32076,33075,34076,34077,34078,34080$ $834082,35079,35081,36080,36082,36083,36084,36085,36086,37085,37086$ $837087,38086,38087,38088,38089,38090,39089,39090,39091,40090,40091$, $\$ 40092,40093,40094,40095,40096,41093,41094,41095,42094,42095,42096$, $842097,42098,42099,42100,43099,44099,44100,44101,44102,44104,44105$, $\$ 44106,46104,46105,46106,46107,46108,46110,47107,47109,47111,48108$, $848110,48111,48112,48113,48114,48601,48116,49113,49115,50115,50116$, $850117,50118,50119,50120,50122,50123,50124,50125,50126,51121,51123$ $851124,51125,51126,52122,52123,52124,52125,52126,52601,52128,52611$, $852130,52132,53127,53129,53130,53131,54128,54129,54130,54131,54132$ $\& 54133,54134,54136,55133,55134,55135,55136,55137,56134,56135,56136$, $\& 56137,56138,56140,57139,57140,58140,58141,58142,58143,58144,59141$ 。 $859142,59143,60142,60143,60144,60145,60146,60150,61151,62147,62148$, $\& 62150,62151,62152,62153,62154,63151,63152,63156,63157,64154,64156$, $864157,64158,64160,65159,65160,66160,66161,66162,66163,66164,67165$, $868166,68167 /$

$\mathrm{nl} f \mathrm{p}=165$

extract nuclides needed for criticality calculations for this c burnup and cooling time. take requested light elements from c the light element library (1st ile entries in iddk/addk),

c actinides from the actinide data (next iact entries in iddk/addk),

c and fission products from the final ifp entries in iddk/addk)

c nlitl will be at least 1, to account for oxygen. the only situation that will allow it to be larger than 1 is if the user has chosen to input a set of isotopics different from the burnup credit nuclides (ie., ttc-0713 or bierman's) and has chosen to enter more light elements than just oxygen

if iflag=1 change all iddk by factor of 10 (from 72 not 71 ) 
iffiflag.eq. 0 )go to 20

do $10 i=1$, $i$ tot

$10 i d d k(i)=i d d k(i) / 10$

20 continue

do $40 \quad i=1$, nlitl

do $30 \mathrm{j}=1$, ile

if(iddk(j).ne.idlit(i)) go to 30

$\operatorname{adl} i t(i)=\operatorname{addk}(j)$

go to 40

30 continue

write(nout, 102) idl itl(i), n71

102 format ( $03 /, * * * *$ error, no match for light element ',i8,

\&' was found on unit $1, i 2$ )

stop 7102

40 continue

nlp1 =ile+1

do $70 i=1$, ncrit

if(idcrit(i).eq.99999)go to 70

aderit $(i)=0.0$

do $60 j=n l p 1$, itot

if(iddk(j).ne.iderit(i)) go to 60

$\operatorname{ader} i t(i)=\operatorname{addk}(j)$

go to 70

60 cont inue

do $65 \mathrm{k}=1, \mathrm{nlitl}$

if(iderit(i).eq.idlitl(k))go to 70

65 continue

write(nout, 103)iderit(i), n71

103 format ('0\%'1****error, no match for nuclide ', i8,

\&' was found on unit ', i2)

stop 7103

70 continue

c add contribution from light element and actinide/fission product libr

do $80 \mathrm{i}=1, \mathrm{nlitl}$

do $80 \mathrm{j}=1$, nerit

if(iderit(j).ne.idtitl(i))go to 80

$\operatorname{adcrit}(j)=\operatorname{adcrit}(j)+\operatorname{adl} i t l(i)$

80 cont inue

c compute number density for lumped-fission product if requested

c only available for $n f i s=-2$ (for mikey's use only)*** adl $f p=0.0$

ifpo=ile+iact

c do we need to calculate a lumped fission product

c check to see if idcrit $=99999$, if so calculate lfp

c also (if ickfp=1) check to see if any nuclide in idcrit is also

c in idlfp, if so set idlfp to zero

c

c ickfp=0 will calculate the virginia power lumped fission product

c explicitly

ickfp=0

c ickfp=1 calculates vp lfp minus fp in iderit array \#don't use now

c ickfp=1

$k 99=0$

do $92 \mathrm{kl}=1$, ncrit

if iderit (kl).eq.99999) k99=kl

if (ickfp.eq.0)go to 92

do $90 j=1, n l f p$

if(idlfp(j).ne.idcrit(kl))go to 90

write(nout, 110$)$ idl $f p(j)$

$i d t p(j)=0$

go to 92

90 continue

92 continue

110 format (i10, ' nuclide was in idlfp and idcrit')

c no Ifp calculation is required if $k 99=0$

if (k99. eq. 0 ) return

do $95 i=1, i f p$ 


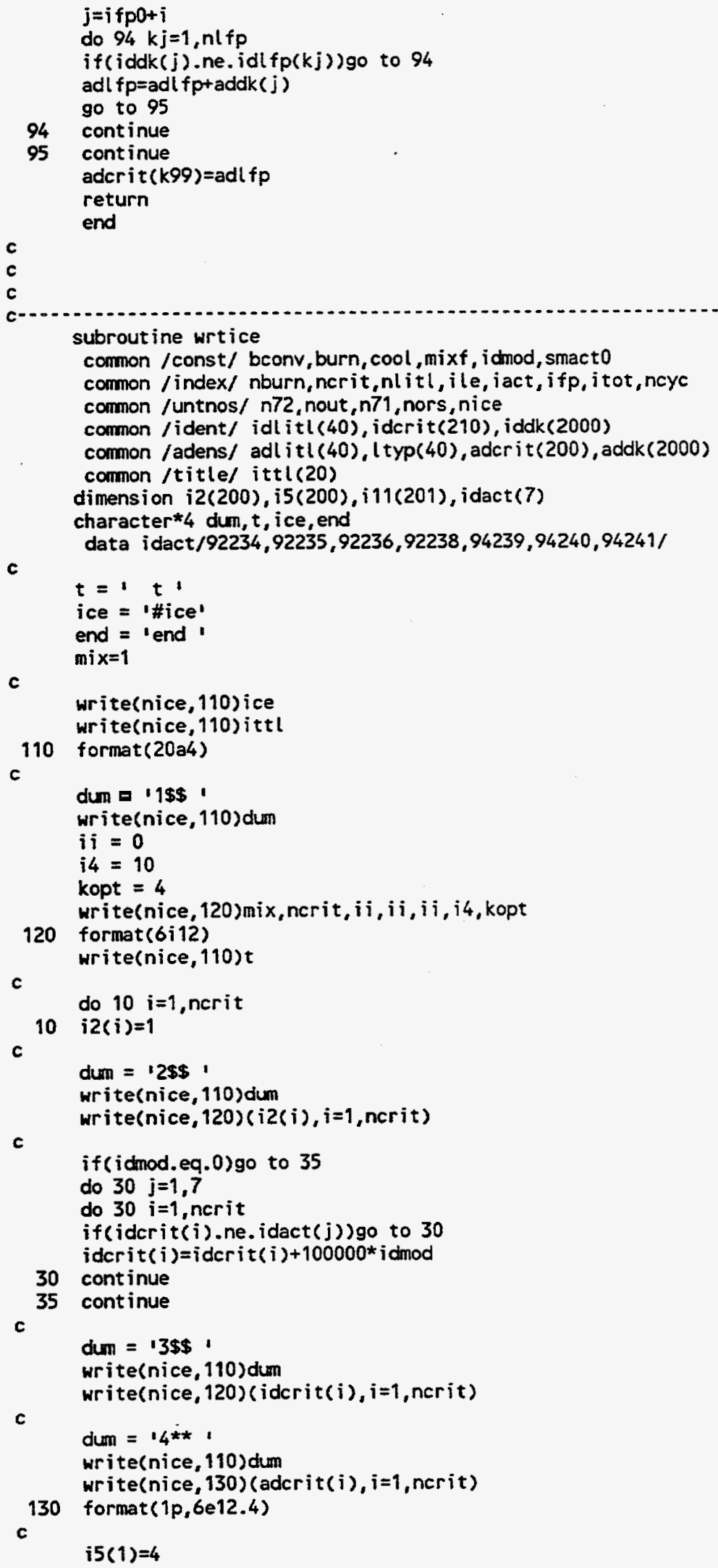


dum $=15 \$ \$$

urite(nice, 110)dum

write(nice, 120)(i5(i), i=1, mix)

write(nice, 110)t

dum $=17 \$ \$$,

write(nice, 110)dum

write(nice, 140)

write(nice, 110)t

140

format(' a $2 \mathrm{e}^{\prime}$ )

$i 11(1)=1$

$i 11(2)=\operatorname{mixf}$

dum $=111 \$ \$ 1$

wrjte(nice, 110)dum

write(nice, 120)(i11(i), $i=1, m i x+1)$

write(nice, 110)t

write(nice, 110)end

return

end

subrout ine wrtkeno

common /const/ bconv, burn, cool, mixf, idmod, smacto

common /index/ nburn, ncrit, nl itl, ile, iact, ifp, i tot, neyc

common /untnos/ $n 72$, nout, n71, nors, nice

common /ident/ idlitl (40), idcrit(210), iddk(2000)

common /adens/ adlitl (40), l typ(40), adcrit (200), addk(2000)

common /title/ ittl(20)

character*2 iname (105), ics $(200)$

dimension mass $(200)$, idact $(7)$

data idact $/ 92234,92235,92236,92238,94239,94240,94241 /$

data iname/' $h$ '.' 'he', 'li', 'be', ' b', ' c',' $n^{\prime},{ }^{\prime} o^{\prime}, f^{\prime} f^{\prime}, '$ 'ne', 'na',

\& 'mg', 'al','si',' $p^{\prime}$, ' s',

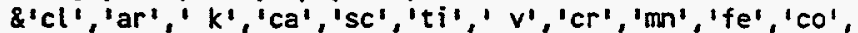

\&'ni', 'cu', 'zn', 'ga', 'ge', 'as', 'se', 'br', 'kr', 'rb',

\&'sr', ' y', '2r', 'nb', 'mo', 'tc', 'ru', 'rh', 'pd', 'ag', 'cd',

\&'in', 'sn', 'sb', 'te',' i', 'xe', 'cs', 'ba', 'la', 'ce'.

\&'pr', 'nd'. 'pm', 'sm', 'eu', 'gd', 'tb', 'dy', 'ho', 'er'.

\&'tm', 'yb', 'lu', 'hf', 'ta', ' w', 're', 'os', 'ir', 'pt',

\&'au', 'hg', 'tl', 'pb', 'bi', 'po', 'at', 'rn', 'fr' 'ra',

\&'ac', 'th', 'pa',' $u^{\prime}$, 'np', 'pu', 'am', 'cm', 'bk', 'cf',

\&'es', 'fm' 'md', 'no', 'Ir', 'rf', 'ha'l

do $15 k=1$,nerit

if(iderit(k).eq.99999)go to 15

iz=iderit $(k) / 1000$

$\operatorname{mass}(k)=i d c r i t(k)-i z * 1000$

idf $f=i z / 100$

if (idff.gt.0)iz=iz-idff*100

$i \operatorname{cs}(k)=$ iname $(i z)$

15 continue

do $20 i=1,4$

20 write(nout, 101)

write(nout, 202)

write(nout, 101)

do $30 j=1$, nerit

if( idcrit(j).eq.99999)go to 30

if $\left(i c s(j)\right.$.eq.' $\left.o^{\prime}\right)$ then

write(nout, 206)ics $(j)$, mixf, adcrit( $j)$

go to 30

end if

if (mass (j).lt.10)write(nout, 203)ics (j), mass $(j), \operatorname{mixf}, \operatorname{adcrit}(j)$

if (mass $(j)$.ge.10.and.mass $(j) .1 t .100)$ write(nout, 204) ics $(j)$.

\&mass $(j), \operatorname{mixf}, \operatorname{adcrit}(j)$

if(mass $(j) . g e .100)$ write(nout, 205)ics $(j), \operatorname{mass}(j)$, mixf, adcrit $(j)$

30 continue

if(idnod.eq.0)go to 5 
do $3 j=1,7$

do 3 i=1, nerit

if(iderit(i).ne.idact( $j$ ))go to 3

idcrit $(i)=i d c r i t(i)+100000 * i d m o d$

3 continue

5 continue

c

$$
\text { do } 10 i=1,4
$$

10 write(nout, 101)

write(nout, 102)

write(nout, 101)

write(nout, 104)mixf

write(nout, 103)(iderit( $j$ ), adcrit $(j), j=1$, ncrit)

return

101 format(a4)

102 format( ' for use when mixing in keno')

103 format $(i 9,2 x, 1 p, e 10.4)$

104 format(' mix=1, i4)

202 format (' for use in csas')

203 format (2x,a2, $\cdots+, i 1,4 x, i 3,2 x, 101,2 x, 1 p, e 10.4, '$ end $)$

204 format $(2 x, a 2,:-1, i 2,3 x, i 3,2 x, 10,2 x, 10, e 10,4, '$ end'

205 format $\left(2 x, a 2, \cdot-1, i 3,2 x, i 3,2 x, 101,2 x, 1 p, e 10.4, \prime^{\prime}\right.$ end' $)$

206 format $(2 x, a 2,6 x, i 3,2 x, 10,2 x, 1 p, e 10.4,1$ end $)$ end 


\section{C.4 SNIKR INPUT LISTING FOR SPENT FUEL ISOTOPICS}

snikr1

nic5 (batch 5) cross section set \#3 $20951 \mathrm{mwd} / \mathrm{mtu}$ read burnup

$n 72=72$

nout $=70$

burn $=20951.0$

ncyc $=8$

end burnup

read decay

nors $=74$

$n 71=71$

cool tme $=0.372$

lightel $=0$

end decay

snikr3

n1c5 (batch 5) cross section set \$3 20951 mwd/mtu

read mxfuel

$n 71=71$

nice $=75$

nout $=73$

ncool $=2$

fisprod $=-2$

$\operatorname{mix} f=1$

icmod $=0$

end mxfuel 


\section{C.5 SNIKR INPUT LISTING FOR DEPLETED BP ISOTOPICS}

snikr1

nic4 bp for 8th-core loc \#11 in cycle 5 a boc $13028 \mathrm{mwd} / \mathrm{mtu}$

read burnup

$n 72=72$

nout $=70$

burn $=13028.0$

ncyc $=6$

end burnup

read decay

nors $=74$

$n 71=71$

cool tme $=0.372$

lightel $=5$

end decay

$\begin{array}{lll}8016 & 0.04497\end{array}$

$11023 \quad 0.0$

130270.0

$5010 \quad 0.0$

50110.0

snikr3

n1c4 bp for 8 th-core loc \#11 in cycle 5 a boc 13028 mwd/mtu read mxfuel

$n 71=71$

nice $=75$

nout $=73$

ncool $=2$

fisprod $=5$

$\operatorname{mixf}=1$

idnod $=0$

end mxfuel

8016110231302750105011 


\section{C.6 SAMPLE SNIKR OUTPUT}

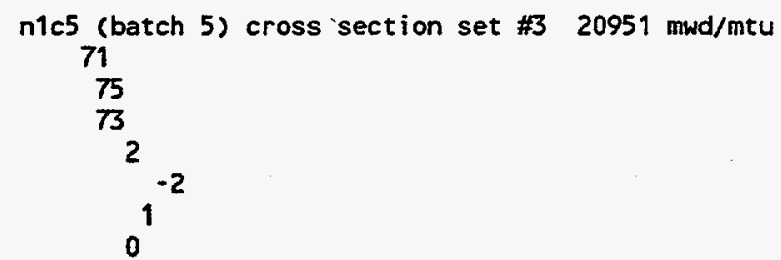

92234922359223692238932379423894239942409424194242 9524195243962448016360834009342095430994410144103 45103451054610546108471095313554131541355513355134 55135591416014360145601476014861147611486114962147 621496215062151621526315363154631556415599999

$\begin{array}{llll}1697 & 689 & 129 & 879 \\ 1697 & 689 & 129 & 879 \\ 1697 & 689 & 129 & 879\end{array}$

$2004 \quad 1.3950 E-07$

$812091.2860 E-26$

$82209 \quad 5.4329 \mathrm{E}-23$

$82214 \quad 1.2295 \mathrm{E}-23$

$83210 \quad 2.4633 \mathrm{E}-22$

$832149.1292 E-24$

$84212 \quad 1.3417 E-28$

84216 1.0191E-22

86219 1.2787E-24

87223 6.4704E-24

$88225 \quad 5.6970 E-21$

$892272.4626 \mathrm{E}-16$

$902284.2293 \mathrm{E}-14$

$902323.7479 E-12$

$912320.0000 E+00$

$912350.0000 E+00$

92233 5.7T37E-11

$92237 \quad 7.5212 E-13$

$922410.0000 E+00$

$93237 \quad 6.5255 E-06$

$93240 \quad 8.6762 E-35$

$94238 \quad 1.2760 \mathrm{E}-06$

$942423.2565 E-06$

$94246 \quad 6.0828 E-29$

$0 \quad 1.2313 E-08$

$952440.0000 E+00$

$96242 \quad 5.6508 \mathrm{E}-08$

$96246 \quad 9.0513 E-10$

$96250 \quad 1.4267 E-22$

$972510.0000 E+00$

$98252 \quad 4.6633 \mathrm{E}-18$

$992532.3090 E-22$

$16250 \quad 0.0000 E+00$

$40097.6542 E-12$

$29066 \quad 3.9961 E-37$

$300683.5390 E-16$

$30070 \quad 3.3258 E-13$

$0 \quad 0.0000 E+00$

$270720.0000 E+00$

$31072 \quad 4.6506 E-34$

$290730.0000 E+00$

$0 \quad 0.0000 E+00$

$30074 \quad 0.0000 E+00$

$280750.0000 E+00$

$320750.0000 E+00$

$290760.0000 E+00$

$33076 \quad 0.0000 E+00$

$30077 \quad 0.0000 E+00$

$33077 \quad 1.0092 E-35$

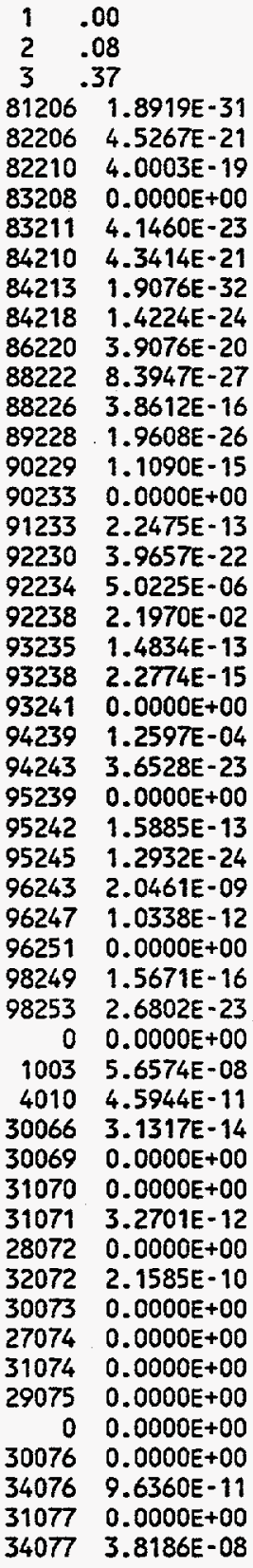

$81207 \quad 9.2165 \mathrm{E}-23$

$82207 \quad 4.8387 E-18$

$82211 \quad 6.9940 E-22$

$83209 \quad 4.5963 \mathrm{E}-19$

$83212 \quad 2.5533 E-18$

0 $0.0000 E+00$

$84214 \quad 1.2923 E-30$

$85217 \quad 1.4987 \mathrm{E}-28$

$86222 \quad 2.5267 E-21$

$882233.1899 E-19$

$88228 \quad 1.6064 \mathrm{E}-22$

$90226 \quad 4.0957 E-25$

$90230 \quad 2.9891 E-11$

$90234 \quad 3.2441 \mathrm{E}-13$

o $1.0938 \mathrm{E}-17$

$92231 \quad 1.4743 E-28$

$92235 \quad 3.7284 E-04$

$922390.0000 E+00$

o $0.0000 E+00$

$932393.7263 \mathrm{E}-13$

$94236 \quad 1.8796 \mathrm{E}-11$

$94240 \quad 3.1510 E-05$

$94244 \quad 4.9214 E-20$

$95240 \quad 4.2951 E-34$

$95243 \quad 4.2591 E-07$

$95246 \quad 1.5197 E-31$

$962445.8912 E-08$

$96248 \quad 4.7605 \mathrm{E}-14$

$972493.3406 E-16$

$98250 \quad 4.7196 \mathrm{E}-17$

$98254 \quad 1.1592 \mathrm{E}-25$

$99254 \quad 0.0000 E+00$

$3006 \quad 1.5730 E-10$

$6014 \quad 6.6352 \mathrm{E}-12$

$29067 \quad 4.3357 \mathrm{E}-33$

$0 \quad 0.0000 E+00$

$32070 \quad 4.5042 E-16$

$32071 \quad 6.6598 E-23$

$290720.0000 E+00$

$27073 \quad 0.0000 E+00$

$31073 \quad 0.0000 E+00$

$28074 \quad 0.0000 E+00$

$30075 \quad 0.0000 E+00$

$33075 \quad 5.5666 \mathrm{E}-09$

$31076 \quad 0.0000 E+00$

$28077 \quad 0.0000 E+00$

$32077 \quad 0.0000 E+00$

$0 \quad 4.0315 E-42$
$320745.7965 E-10$
$81208 \quad 4.6274 E-20$

$82208 \quad 9.2674 \mathrm{E}-15$

$82212 \quad 2.6918 E-17$

$0 \quad 0.0000 E+00$

$832131.2689 \mathrm{E}-23$

$842114.5820 E-28$

$84215 \quad 5.7476 E-28$

$86218 \quad 7.7319 E-30$

87221 1.3641E-24

$882242.2223 E-16$

89225 4.0088E-21

$90227 \quad 5.3612 E-19$

$902311.5422 \mathrm{E}-15$

91231 1.0163E-11

$91234 \quad 4.8858 E-18$

$922326.7165 E-12$

$92236 \quad 7.8727 \mathrm{E}-05$

$92240 \quad 9.8816 \mathrm{E}-31$

$93236 \quad 1.7745 E-11$

$0 \quad 8.4333 E-33$

$94237 \quad 1.0693 \mathrm{E}-13$

$94241 \quad 1.9067 \mathrm{E}-05$

$94245 \quad 0.0000 E+00$

$952418.2065 \mathrm{E}-07$

$0 \quad 0.0000 E+00$

$962411.8949 \mathrm{E}-18$

96245 1.6737E-09

$962492.0832 E-28$

$97250 \quad 4.2123 E-31$

$98251 \quad 2.1653 \mathrm{E}-17$

$982550.0000 E+00$

$992550.0000 E+00$

$3007 \quad 5.1087 E-12$

$28066 \quad 2.5634 E-34$

30067 4.1637E-15

$310691.2734 E-14$

$300710.0000 E+00$

$0 \quad 0.0000 E+00$

$30072 \quad 1.0686 E-33$

$28073 \quad 0.0000 E+00$

$32073 \quad 6.8707 E-10$

$29074 \quad 0.0000 E+00$

$27075 \quad 0.0000 E+00$

$31075 \quad 0.0000 E+00$

$28076 \quad 0.0000 E+00$

$32076 \quad 1.7032 \mathrm{E}-08$

$29077 \quad 0.0000 E+00$

$0 \quad 0.0000 E+00$

$28078 \quad 0.0000 E+00$ 


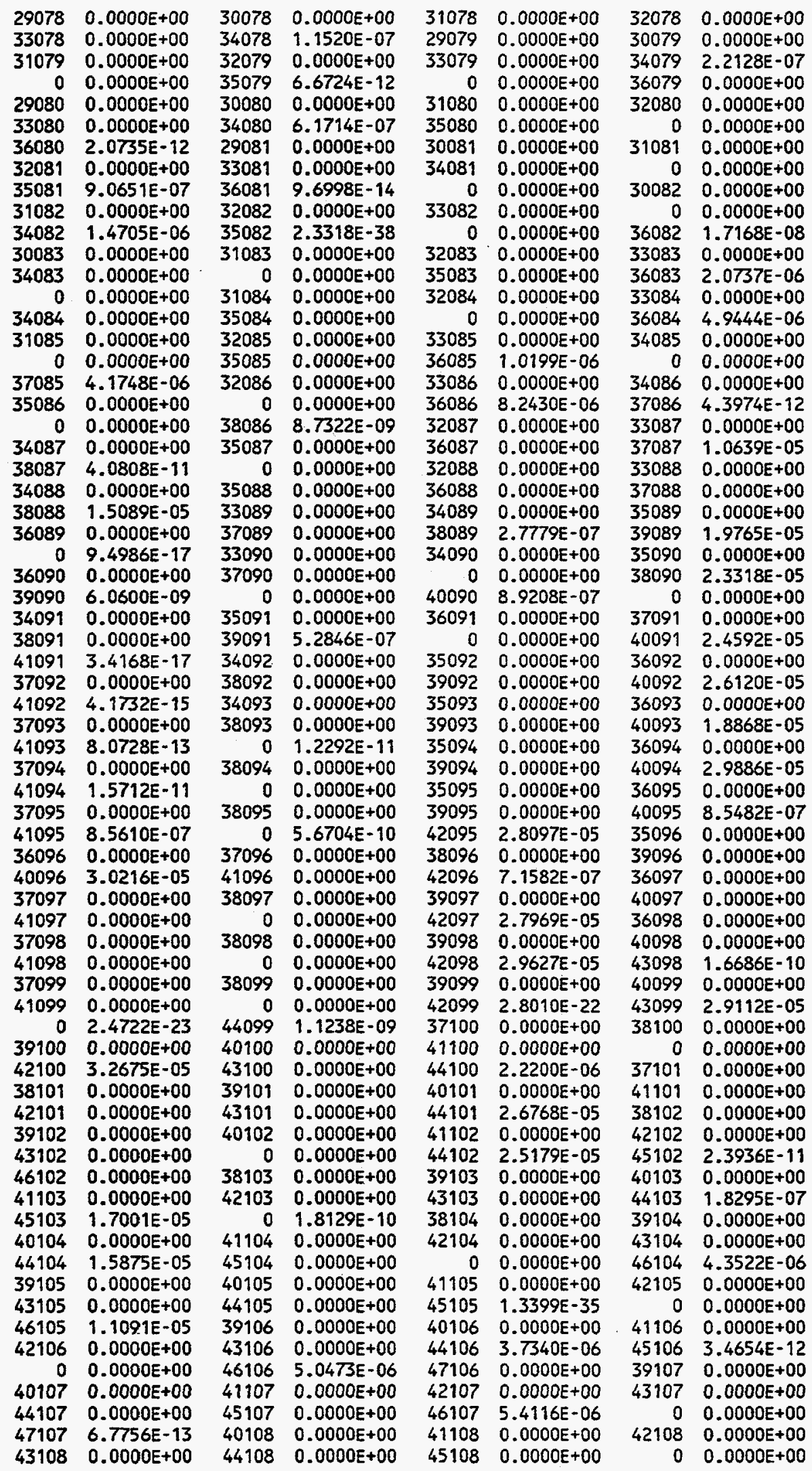




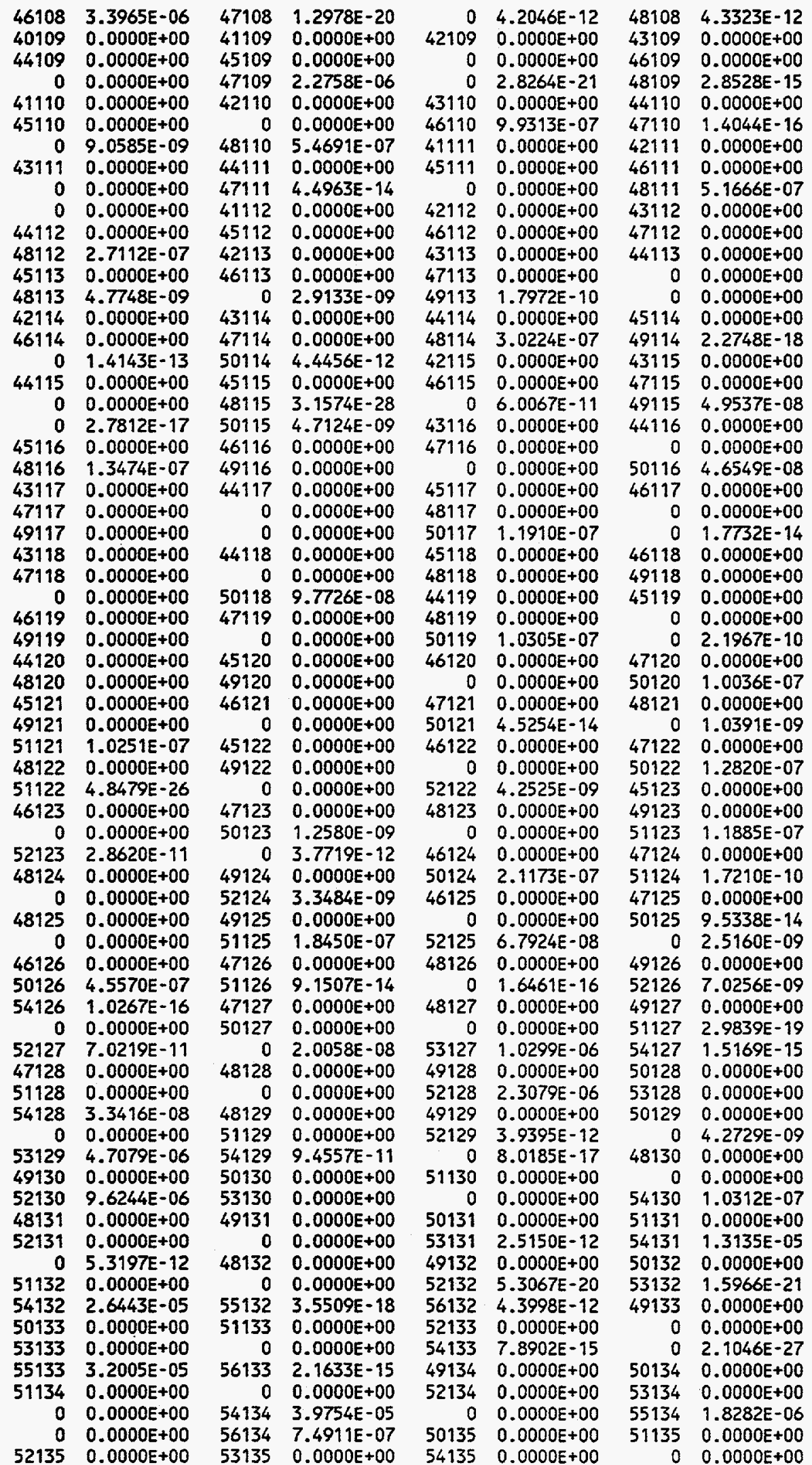




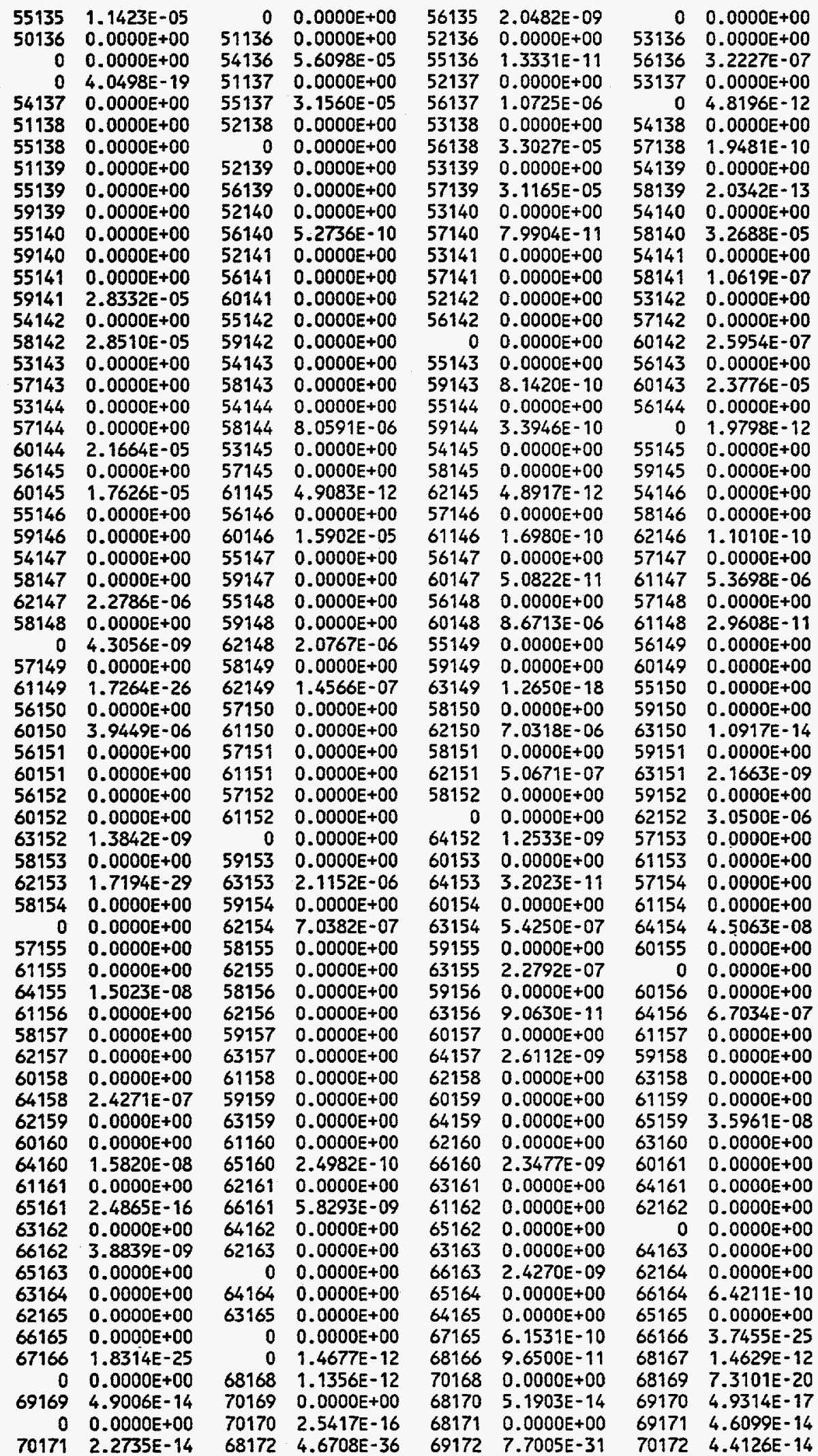
adlitl for $8016=0.0000 E+00$ 
isotopic results for cool step 3 origens cooling time $(y r)=.37$

for use in csas

\begin{tabular}{|c|c|c|c|}
\hline 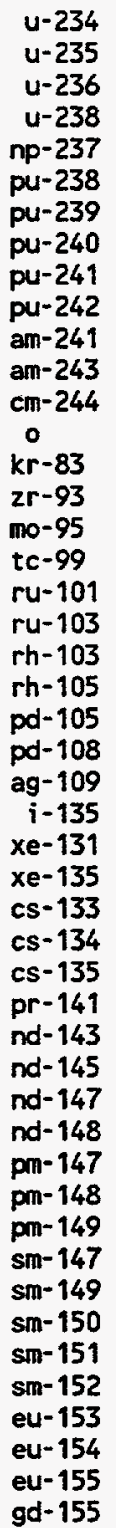 & $\begin{array}{l}1 \\
1 \\
1 \\
1 \\
1 \\
1 \\
1 \\
1 \\
1 \\
1 \\
1 \\
1 \\
1 \\
1 \\
1 \\
1 \\
1 \\
1 \\
1 \\
1 \\
1 \\
1 \\
1 \\
1 \\
1 \\
1 \\
1 \\
1 \\
1 \\
1 \\
1 \\
1 \\
1 \\
1 \\
1 \\
1 \\
1 \\
1 \\
1 \\
1 \\
1 \\
1 \\
1 \\
1 \\
1 \\
1 \\
1 \\
1 \\
1\end{array}$ & $\begin{array}{l}0 \\
0 \\
0 \\
0 \\
0 \\
0 \\
0 \\
0 \\
0 \\
0 \\
0 \\
0 \\
0 \\
0 \\
0 \\
0 \\
0 \\
0 \\
0 \\
0 \\
0 \\
0 \\
0 \\
0 \\
0 \\
0 \\
0 \\
0 \\
0 \\
0 \\
0 \\
0 \\
0 \\
0 \\
0 \\
0 \\
0 \\
0 \\
0 \\
0 \\
0 \\
0 \\
0 \\
0 \\
0 \\
0 \\
0 \\
0\end{array}$ & $\begin{array}{l}5.0225 E-06 \\
3.7284 E-04 \\
7.8727 E-05 \\
2.1970 E-02 \\
6.5255 E-06 \\
1.2760 E-06 \\
1.2597 E-04 \\
3.1510 E-05 \\
1.9067 E-05 \\
3.2565 E-06 \\
8.2065 E-07 \\
4.2591 E-07 \\
5.8912 E-08 \\
4.6252 E-02 \\
2.0737 E-06 \\
1.8868 E-05 \\
2.8097 E-05 \\
2.9112 E-05 \\
2.6768 E-05 \\
1.8295 E-07 \\
1.7001 E-05 \\
1.3399 E-35 \\
1.1091 E-05 \\
3.3965 E-06 \\
2.2758 E-06 \\
0.0000 E+00 \\
1.3135 E-05 \\
0.0000 E+00 \\
3.2005 E-05 \\
1.8282 E-06 \\
1.1423 E-05 \\
2.8332 E-05 \\
2.3776 E-05 \\
1.7626 E-05 \\
5.0822 E-11 \\
8.6713 E-06 \\
5.3698 E-06 \\
2.9608 E-11 \\
1.7264 E-26 \\
2.2786 E-06 \\
1.4566 E-00 \\
7.0318 E-06 \\
5.0671 E-07 \\
3.0500 E-06 \\
2.1152 E-06 \\
5.4250 E-07 \\
2.2792 E-07 \\
1.5023 E-08\end{array}$ \\
\hline
\end{tabular}

for use when mixing in keno

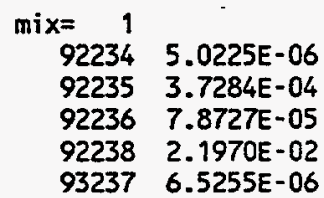


$\begin{array}{rl}94238 & 1.2760 E-06 \\ 94239 & 1.2597 E-04 \\ 94240 & 3.1510 E-05 \\ 94241 & 1.9067 E-05 \\ 94242 & 3.2565 E-06 \\ 95241 & 8.2065 E-07 \\ 95243 & 4.2591 E-07 \\ 96244 & 5.8912 E-08 \\ 8016 & 4.6252 E-02 \\ 36083 & 2.0737 E-06 \\ 40093 & 1.8868 E-05 \\ 42095 & 2.8097 E-05 \\ 43099 & 2.9112 E-05 \\ 44101 & 2.6768 E-05 \\ 44103 & 1.8295 E-07 \\ 45103 & 1.7001 E-05 \\ 45105 & 1.3399 E-35 \\ 46105 & 1.1091 E-05 \\ 46108 & 3.3965 E-06 \\ 47109 & 2.2758 E-06 \\ 53135 & 0.0000 E+00 \\ 54131 & 1.3135 E-05 \\ 54135 & 0.0000 E+00 \\ 55133 & 3.2005 E-05 \\ 55134 & 1.8282 E-06 \\ 55135 & 1.1423 E-05 \\ 59141 & 2.8332 E-05 \\ 60143 & 2.3776 E-05 \\ 60145 & 1.7626 E-05 \\ 60147 & 5.0822 E-11 \\ 60148 & 8.6713 E-06 \\ 61147 & 5.3698 E-06 \\ 61148 & 2.9608 E-11 \\ 61149 & 1.7264 E-26 \\ 62147 & 2.2786 E-06 \\ 62149 & 1.4566 E-07 \\ 62150 & 7.0318 E-06 \\ 62151 & 5.0671 E-07 \\ 62152 & 3.0500 E-06 \\ 63153 & 2.1152 E-06 \\ 63154 & 5.4250 E-07 \\ 63155 & 2.2792 E-07 \\ 64155 & 1.5023 E-08 \\ 99999 & 9.7763 E-04\end{array}$ 
APPENDIX D

CSASN INPUT LISTINGS 


\section{D.1 CSASN INPUT LISTING FOR CROSS-SECTION SET 3}

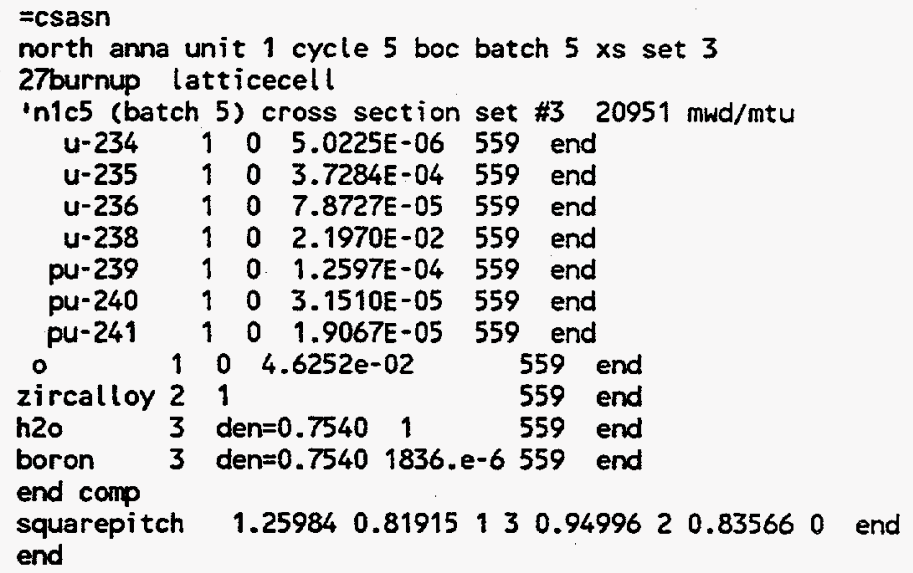




\section{D.2 CSASN INPUT LISTING FOR CROSS-SECTION SET 4}

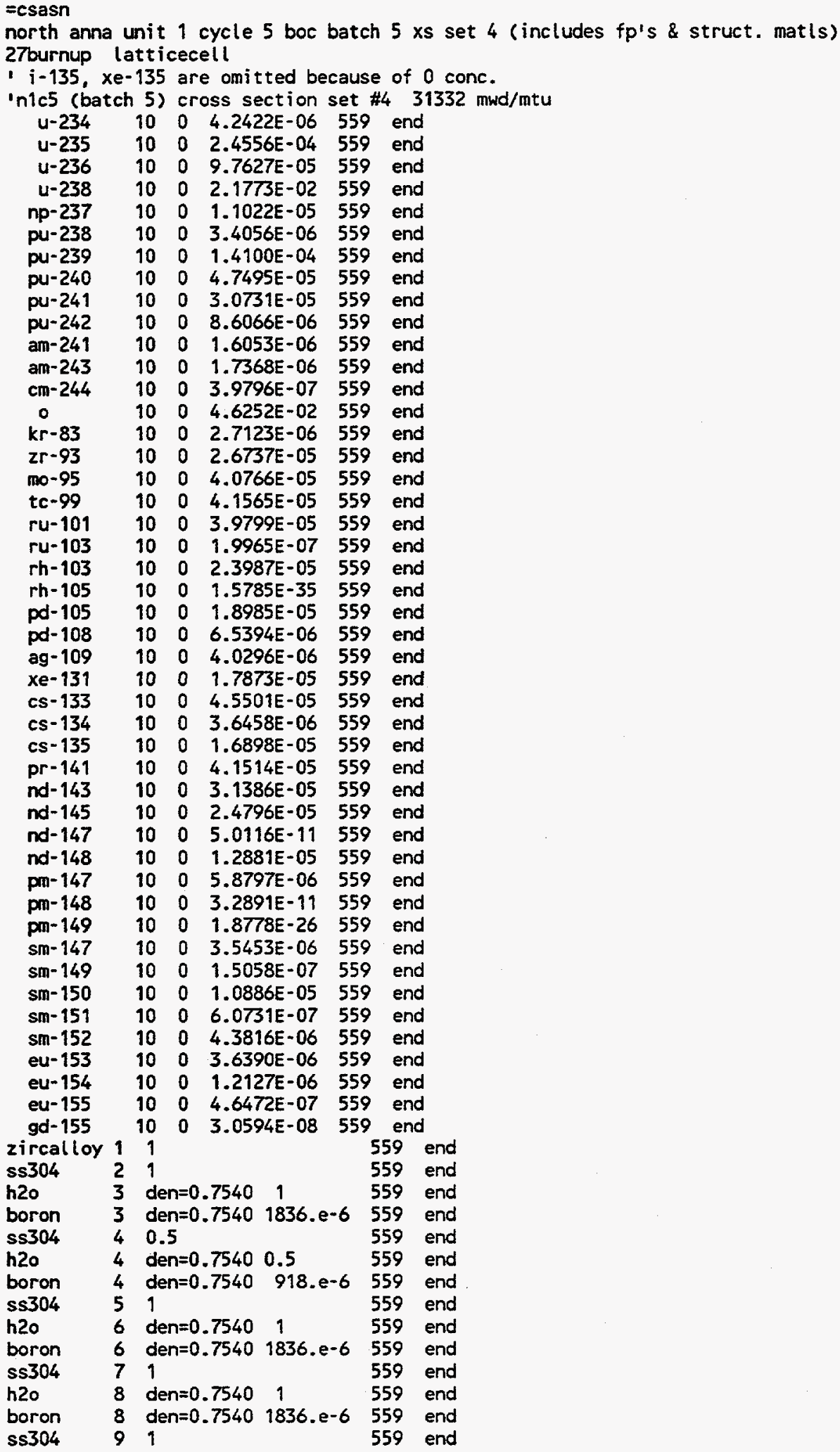


end comp

squarepitch $1.259840 .819151030 .94996 \quad 1 \quad 0.83566 \quad 0$ end end 
APPENDIX E

WAX INPUT LISTING 
=wax

'write final library to unit $4 /$ biggest input $l$ ib is on unit 36

$0 \$ 436$

' input xsec's from 11 libs

$1 \$ \$ 11 \quad t$

- input xsec's for fuel xsec set 1

$2 \$ \$ 337 \mathrm{t}$

$\begin{array}{llllllll}3 \$ \$ & 92234 & 92235 & 92236 & 92238 & 94239 & 94240 & 94241\end{array}$

4\$\$ 192234192235192236192238194239194240194241 t

input $x \sec ^{\prime} s$ for fuel $x$ sec set 2

$25 \$ 347 t$

3\$\$ $92234 \quad 92235 \quad 92236 \quad 92238 \quad 94239 \quad 94240 \quad 94241$

$4 \$ \$ 292234292235292236292238294239294240294241$ t

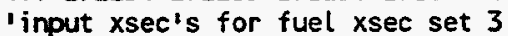

$2 \$ \$ 357 \mathrm{t}$

$\begin{array}{llllllll}3 \$ \$ & 92234 & 92235 & 92236 & 92238 & 94239 & 94240 & 94241\end{array}$

4S\$ $392234392235392236392238394239394240394241 t$

input xsec's for fuel xsec set $4+f^{\prime}$ 's + struct. mat'is

$2 \$ 360 t$

input xsec's for fuel xsec set 5

$2 \$ \$ 377 \mathrm{t}$

$\begin{array}{lllllll}3 \$ \$ 92234 & 92235 & 92236 & 92238 & 94239 & 94240 & 94241\end{array}$

$4 \$ \$ 592234592235592236592238594239594240594241 t$

input xsec's for fuel xsec set 6

$2 \$ 387 t$

$\begin{array}{llllllll}3 \$ \$ & 92234 & 92235 & 92236 & 92238 & 94239 & 94240 & 94241\end{array}$

$4 \$ \$ 692234692235692236692238694239694240694241 t$

input xsec's for fuel xsec set 7

$2 \$ 397 t$

$\begin{array}{llllllll}3 \$ \$ & 92234 & 92235 & 92236 & 92238 & 94239 & 94240 & 94241\end{array}$

4\$\$ $792234792235792236792238794239794240794241 t$

'input Xsec's for fuel xsec set $8+$ bp's

$2 \$ \$ 4010 t$

$\begin{array}{llllllll}3 \$ \$ & 92234 & 92235 & 92236 & 92238 & 94239 & 94240 & 94241\end{array}$

$408016 \quad 405010 \quad 405011$

4\$\$ 892234892235892236892238 894239894240894241 $818016815010815011 t$

input xsec's for fuel xsec set $9+$ bp's

$2 \$ \$ 17 t$

3s\$ $92234 \quad 92235 \quad 92236 \quad 92238$

$408016 \quad 405010 \quad 405011$

$4 \$ \$ 992234992235992236992238$

$918016915010915011 \mathrm{t}$

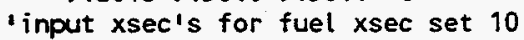

$2 \$ \$ 424$

$\begin{array}{lllll}3 \$ \$ & 92234 & 92235 & 92236 & 92238\end{array}$

$4 \$ \$ 1092234109223510922361092238$ t

input xsec's for fuel xsec set $11+$ bp's

$2 \$ \$ 39 t$

$\begin{array}{lllll}3 \$ \$ & 92234 & 92235 & 92236 & 92238\end{array}$

$\begin{array}{llllll}408016 & 11023 & 13027 & 405010 & 405011\end{array}$

4\$\$ $119223411922351192236 \quad 1192238$

$\begin{array}{llrlll}1118016 & 11023 & 13027 & 1115010 & 1115011 & t\end{array}$

end 
APPENDIX F

KENO V.a INPUT LISTING 


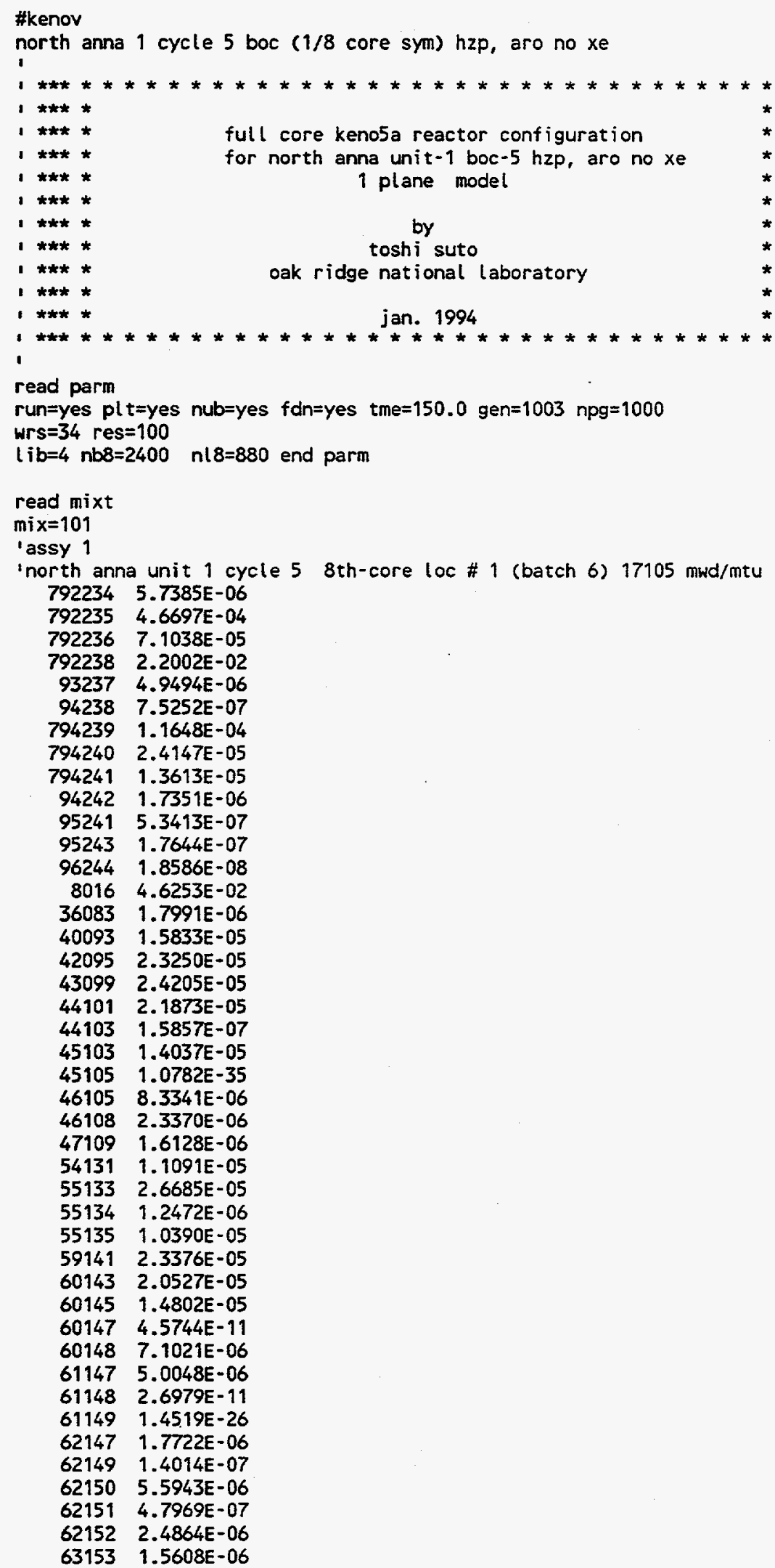




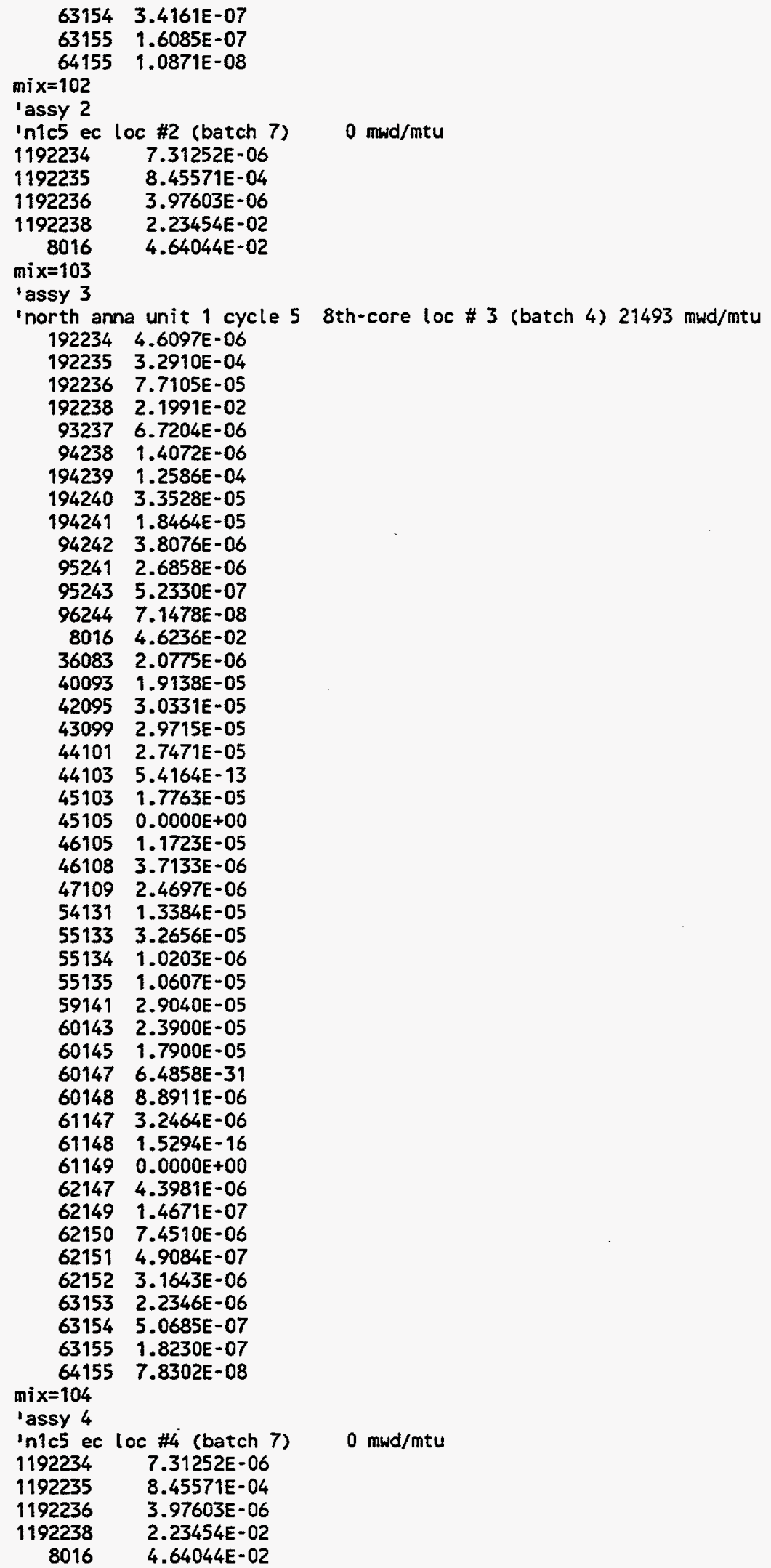




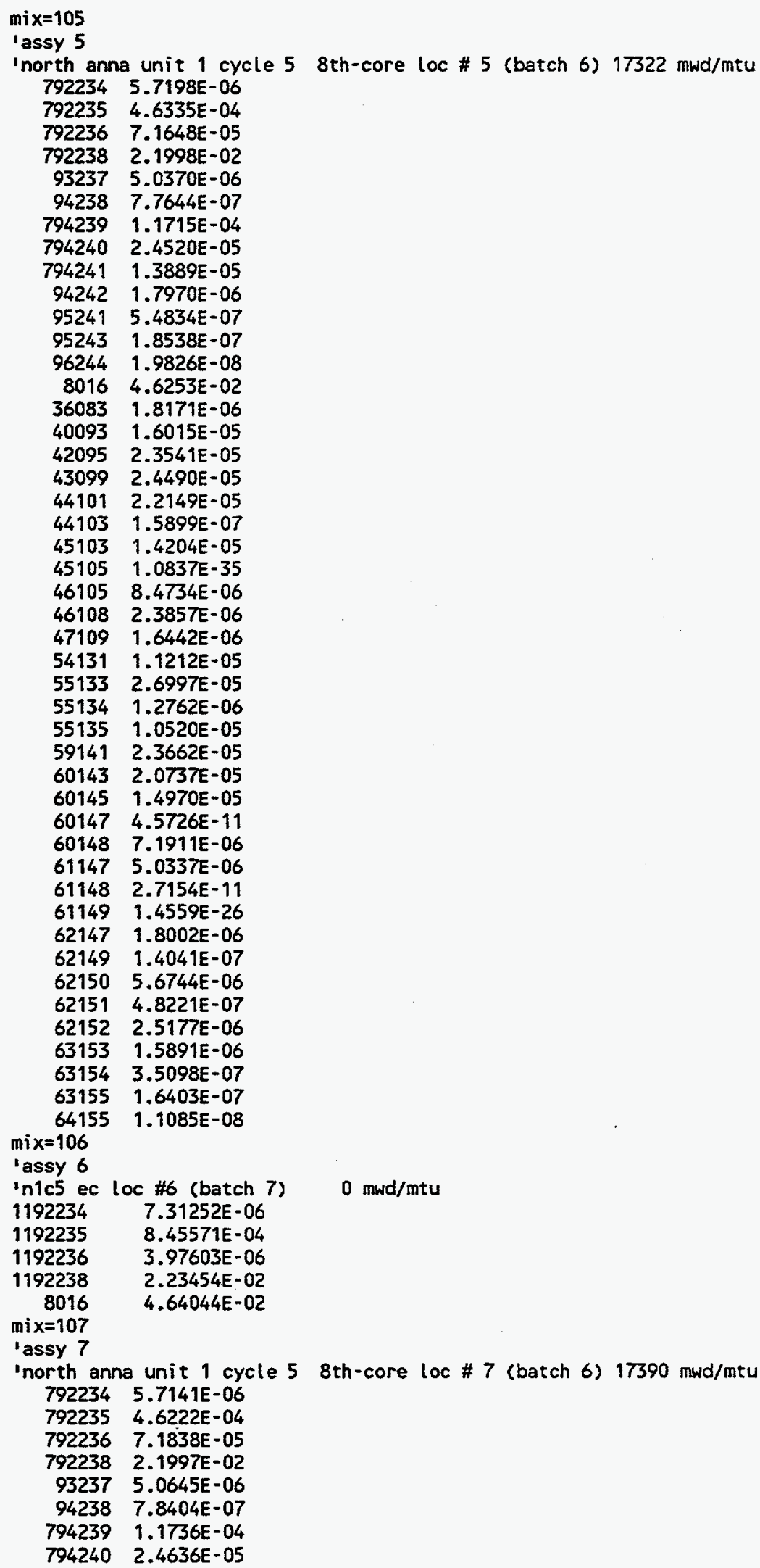




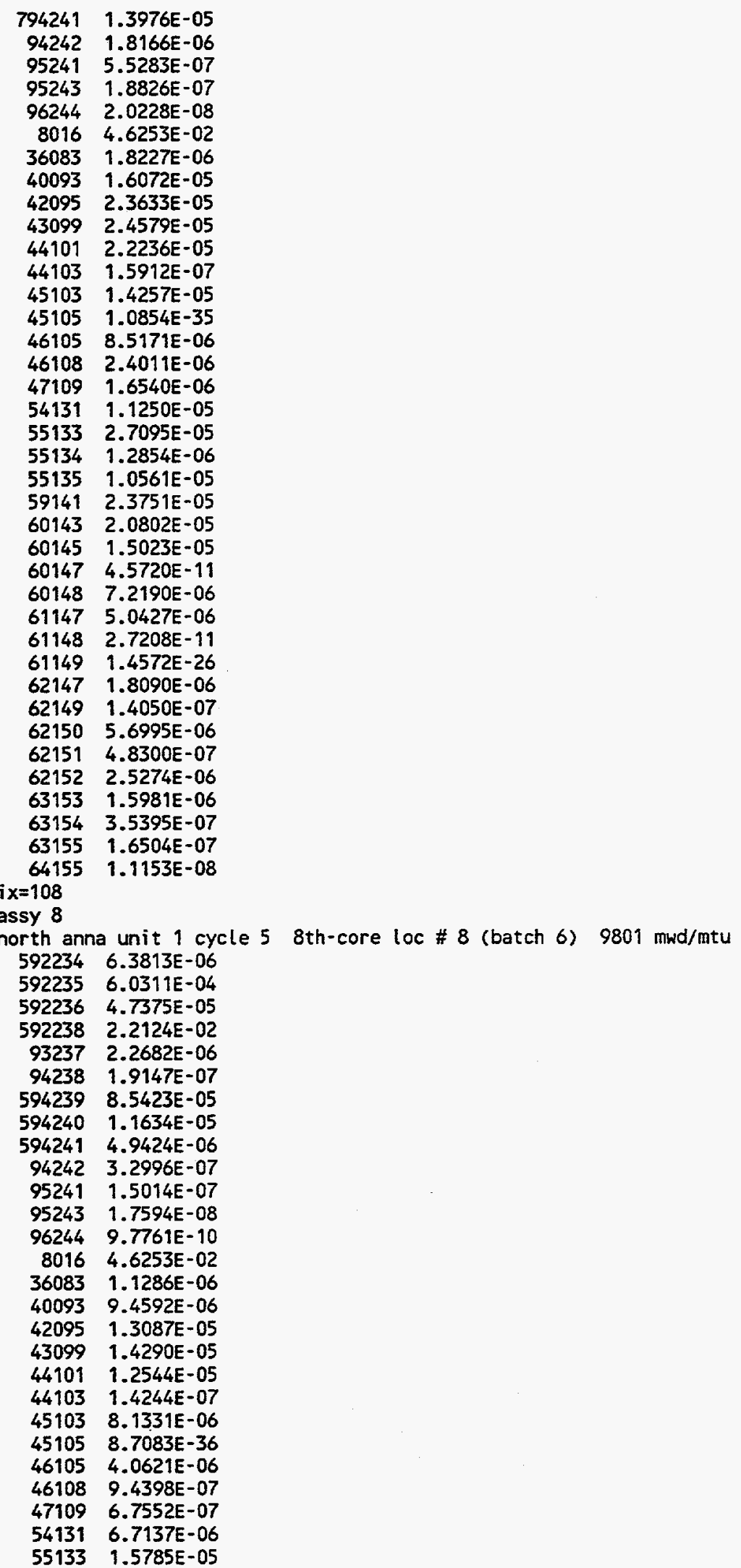




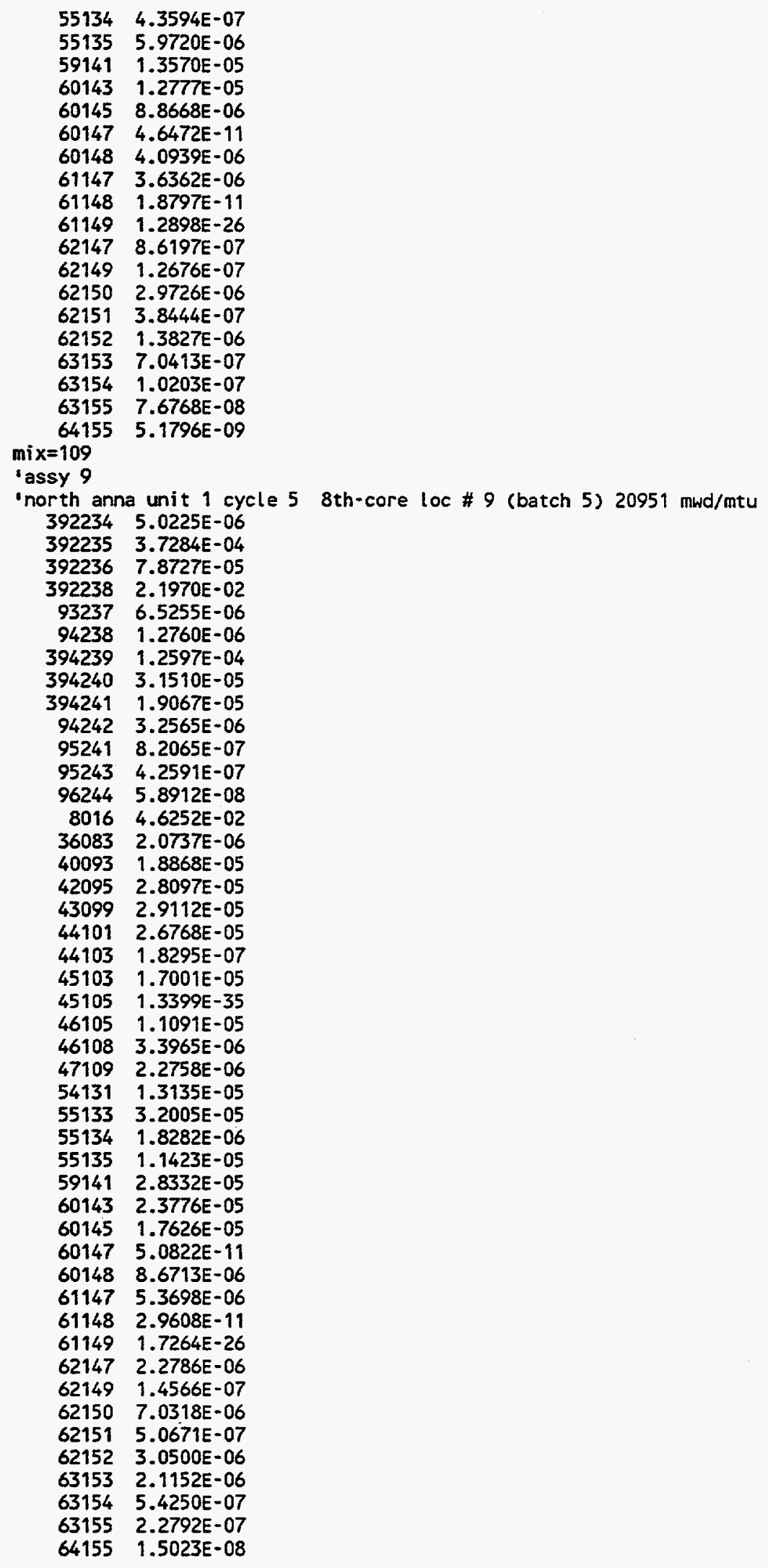




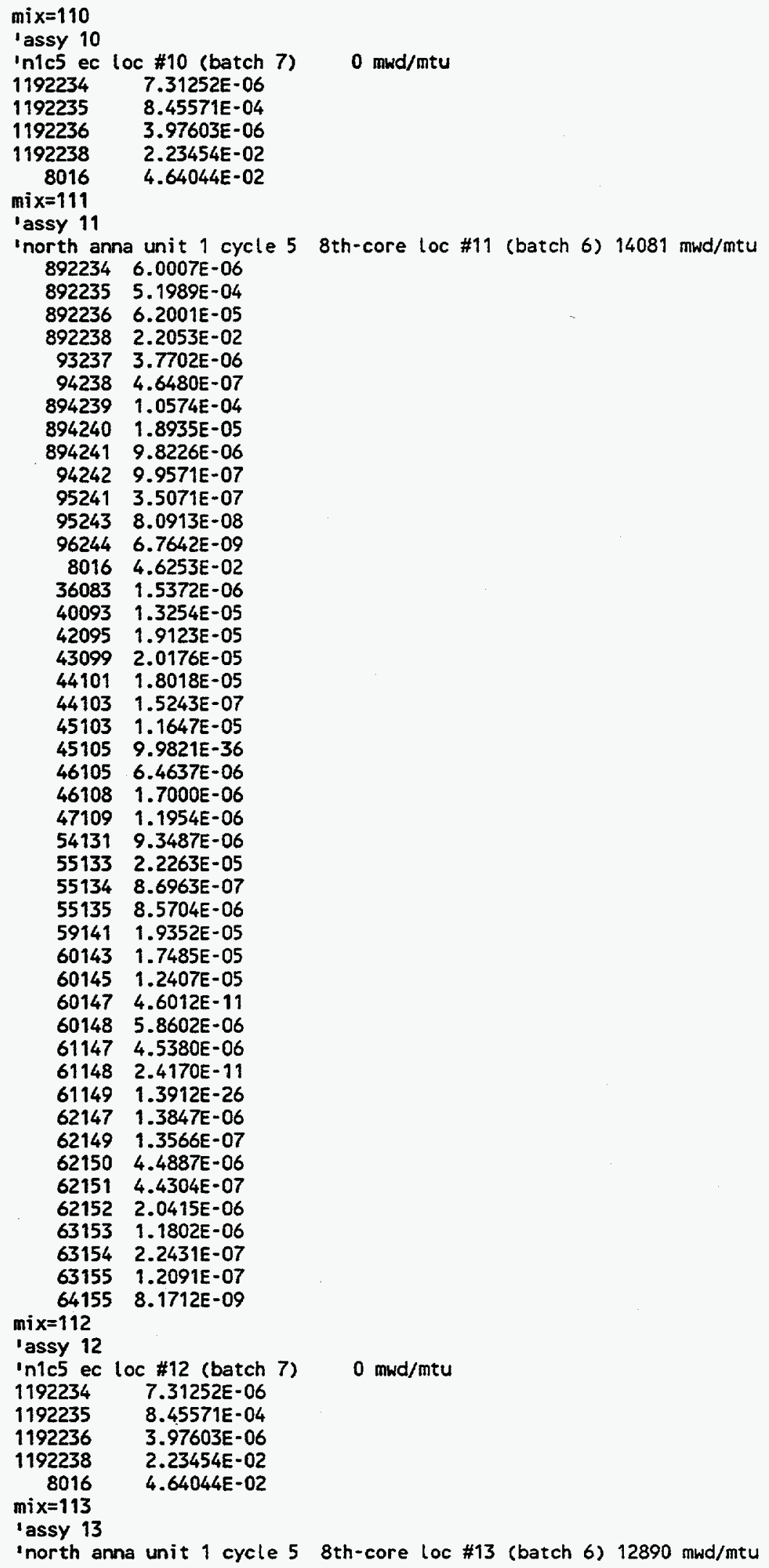




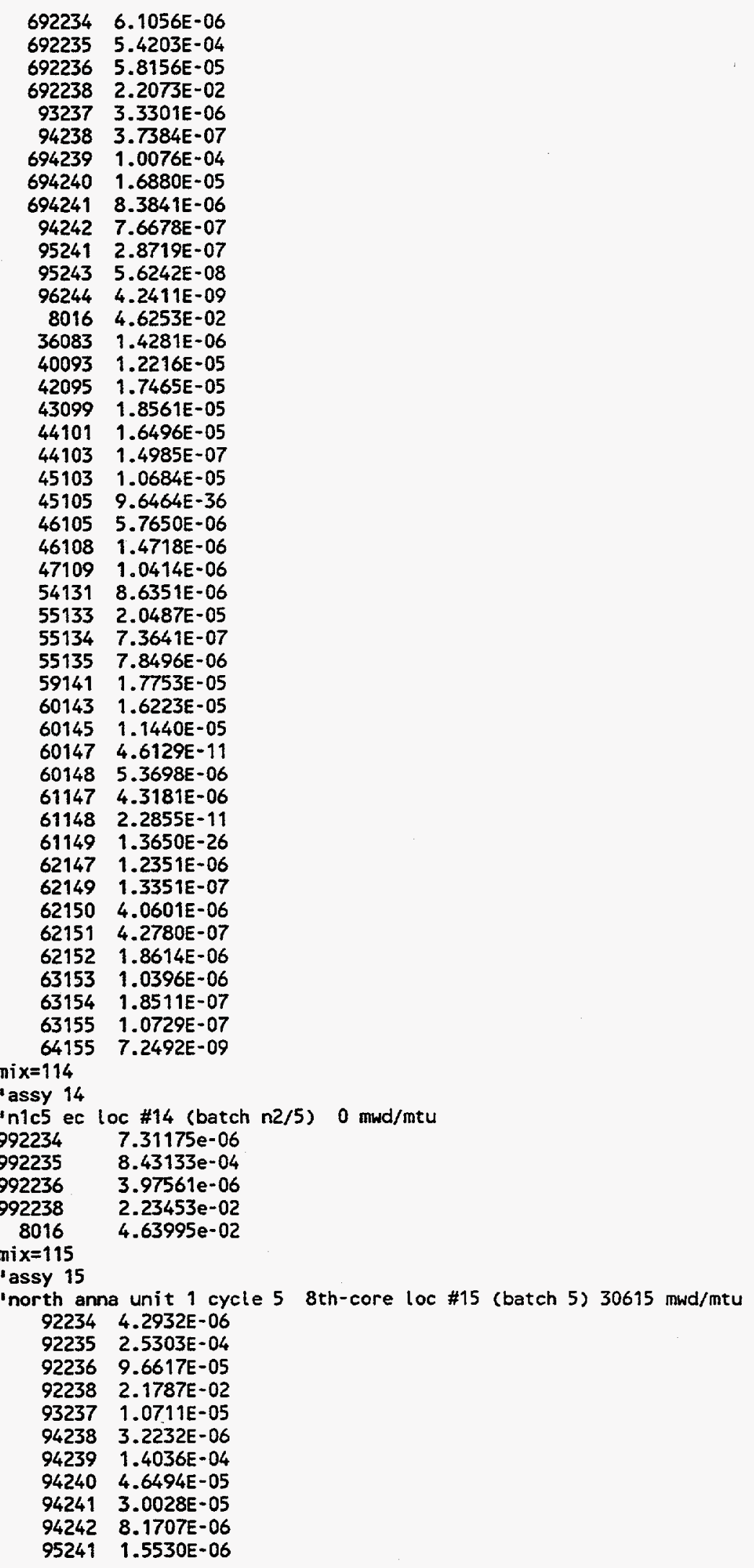


$\begin{array}{rr}95243 & 1.6103 E-06 \\ 96244 & 3.5818 E-07 \\ 8016 & 4.6252 E-02 \\ 36083 & 2.6751 E-06 \\ 40093 & 2.6219 E-05 \\ 42095 & 3.9933 E-05 \\ 43099 & 4.0747 E-05 \\ 44101 & 3.8908 E-05 \\ 44103 & 1.9864 E-07 \\ 45103 & 2.3547 E-05 \\ 45105 & 1.5638 E-35 \\ 46105 & 1.8406 E-05 \\ 46108 & 6.2993 E-06 \\ 47109 & 3.9046 E-06 \\ 54131 & 1.7584 E-05 \\ 55133 & 4.4620 E-05 \\ 55134 & 3.5091 E-06 \\ 55135 & 1.6525 E-05 \\ 59141 & 4.0621 E-05 \\ 60143 & 3.0938 E-05 \\ 60145 & 2.4330 E-05 \\ 60147 & 5.0157 E-11 \\ 60148 & 1.2592 E-05 \\ 61147 & 5.8644 E-06 \\ 61148 & 3.2785 E-11 \\ 61149 & 1.8694 E-26 \\ 62147 & 3.4653 E-06 \\ 62149 & 1.5046 E-07 \\ 62150 & 1.0623 E-05 \\ 62151 & 6.0090 E-07 \\ 62152 & 4.2953 E-06 \\ 63153 & 3.5325 E-06 \\ 63154 & 1.1608 E-06 \\ 63155 & 4.4589 E-07 \\ 64155 & 2.9358 E-08\end{array}$

$\operatorname{mix}=116$

Iassy 16

'north anna unit 1 cycle 5 8th-core loc \#16 (batch 6) $17158 \mathrm{mwd} / \mathrm{mtu}$ $792234 \quad 5.7339 E-06$

792235 4.6609E-04

$792236 \quad 7.1187 \mathrm{E}-05$

$792238 \quad 2.2001 E-02$

$93237 \quad 4.9707 E-06$

$94238 \quad 7.5832 E-07$

$7942391.1665 \mathrm{E}-04$

$794240 \quad 2.4238 E-05$

$794241 \quad 1.3681 E-05$

$942421.7501 E-06$

$95241 \quad 5.3759 E-07$

$95243 \quad 1.7859 \mathrm{E}-07$

$96244 \quad 1.8883 E-08$

$8016 \quad 4.6253 E-02$

$36083 \quad 1.8035 E-06$

$40093 \quad 1.5877 E-05$

42095 2.3322E-05

$430992.4275 E-05$

$441012.1940 E-05$

$44103 \quad 1.5868 \mathrm{E}-07$

$45103 \quad 1.4078 \mathrm{E}-05$

$45105 \quad 1.0796 \mathrm{E}-35$

$46105 \quad 8.3681 E-06$

$46108 \quad 2.3488 E-06$

$47109 \quad 1.6205 E-06$

54131 1.1121E-05

$55133 \quad 2.6761 \mathrm{E}-05$

$551341.2542 E-06$

55135 1.0422E-05

$59141 \quad 2.3445 E-05$ 


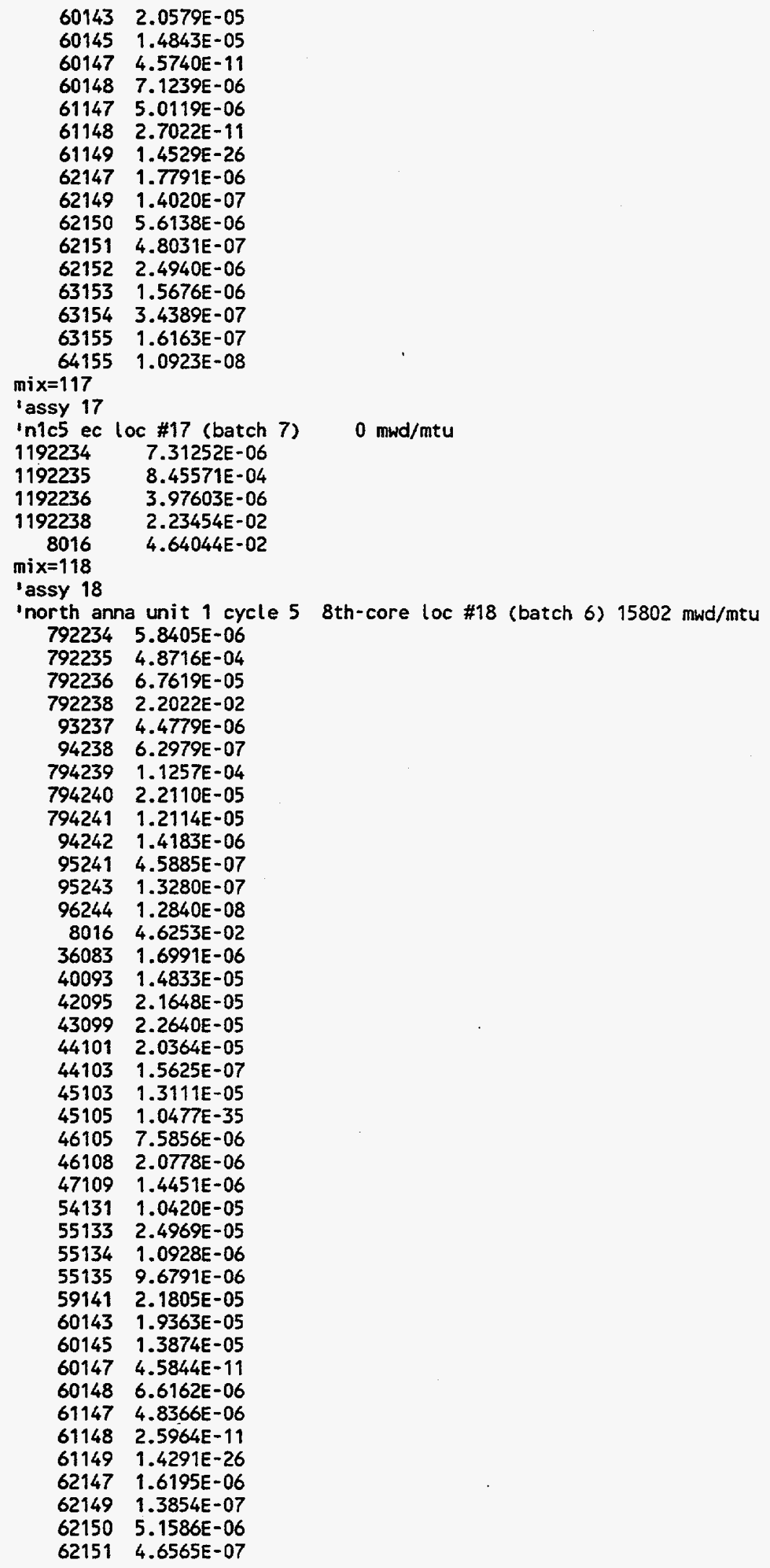




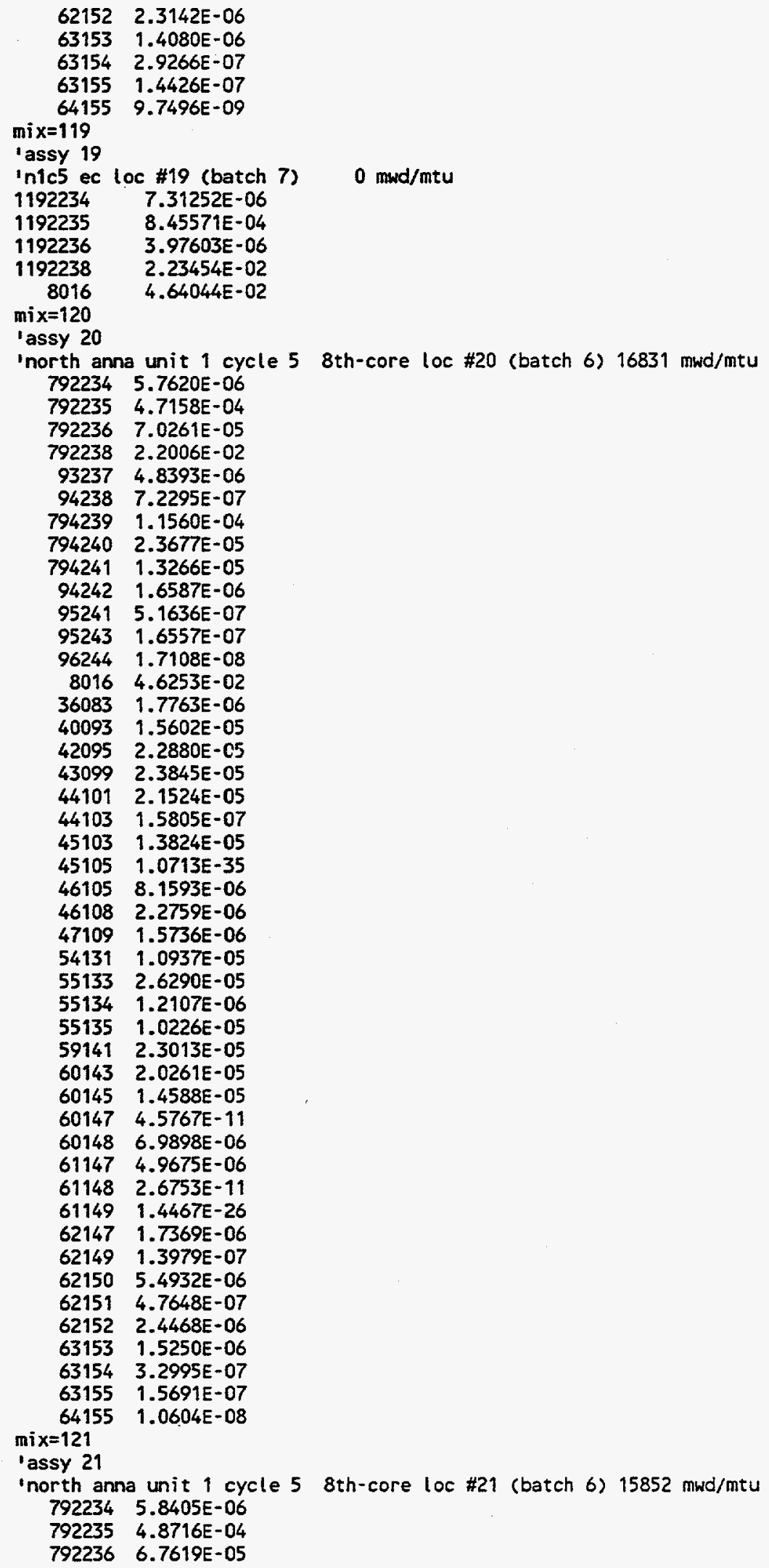




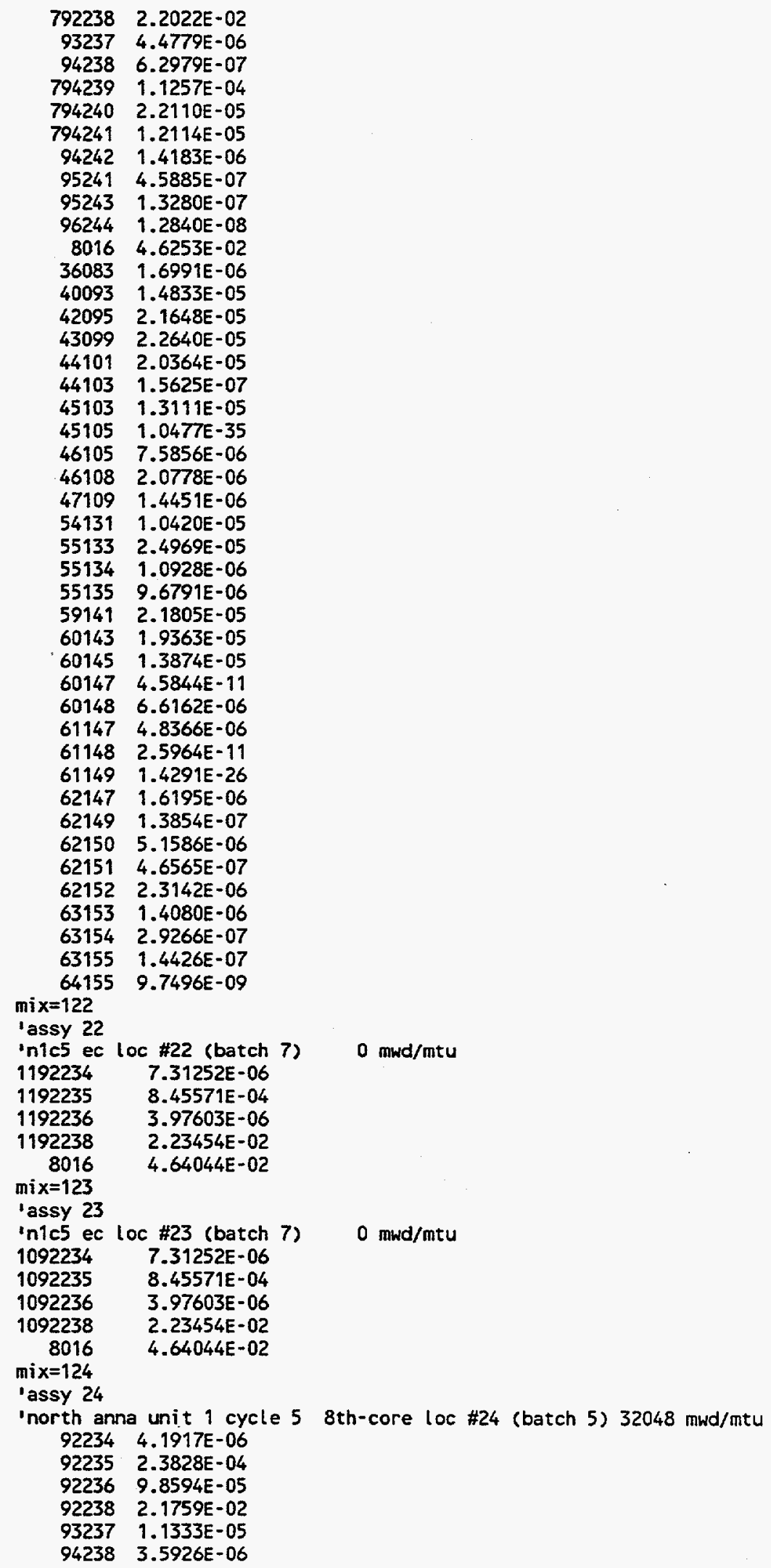


$\begin{array}{ll}94239 & 1.4160 \mathrm{E}-04 \\ 94240 & 4.8476 \mathrm{E}-05 \\ 94241 & 3.1416 \mathrm{E}-05 \\ 94242 & 9.0501 \mathrm{E}-06 \\ 95241 & 1.6567 \mathrm{E}-06 \\ 95243 & 1.8686 \mathrm{E}-06 \\ 96244 & 4.4078 \mathrm{E}-07 \\ 8016 & 4.6252 \mathrm{E}-02 \\ 36083 & 2.7485 \mathrm{E}-06 \\ 40093 & 2.7251 \mathrm{E}-05 \\ 42095 & 4.1592 \mathrm{E}-05 \\ 43099 & 4.2376 \mathrm{E}-05 \\ 44101 & 4.0688 \mathrm{E}-05 \\ 44103 & 2.0065 \mathrm{E}-07 \\ 45103 & 2.4419 \mathrm{E}-05 \\ 45105 & 1.5928 \mathrm{E}-35 \\ 46105 & 1.9567 \mathrm{E}-05 \\ 46108 & 6.7822 \mathrm{E}-06 \\ 47109 & 4.1549 \mathrm{E}-06 \\ 54131 & 1.8158 \mathrm{E}-05 \\ 55133 & 4.6373 \mathrm{E}-05 \\ 55134 & 3.7838 \mathrm{E}-06 \\ 55135 & 1.7270 \mathrm{E}-05 \\ 59141 & 4.2403 \mathrm{E}-05 \\ 60143 & 3.1823 \mathrm{E}-05 \\ 60145 & 2.5257 \mathrm{E}-05 \\ 60147 & 5.0074 \mathrm{E}-11 \\ 60148 & 1.3169 \mathrm{E}-05 \\ 61147 & 5.8926 \mathrm{E}-06 \\ 61148 & 3.2982 \mathrm{E}-11 \\ 61149 & 1.8860 \mathrm{E}-26 \\ 62147 & 3.6240 \mathrm{E}-06 \\ 62149 & 1.5068 \mathrm{E}-07 \\ 62150 & 1.1148 \mathrm{E}-05 \\ 62151 & 6.1362 \mathrm{E}-07 \\ 62152 & 4.4669 \mathrm{E}-06 \\ 63153 & 3.7453 \mathrm{E}-06 \\ 63154 & 1.2653 \mathrm{E}-06 \\ 63155 & 4.8381 \mathrm{E}-07 \\ 64155 & 3.1846 \mathrm{E}-08 \\ 6 & \end{array}$

$\operatorname{mix}=125$

'assy 25

'north anna unit 1 cycle 5 8th-core loc \#25 (batch 6) 12139 mwd/mtu $6922346.1721 E-06$

$692235 \quad 5.5638 \mathrm{E}-04$

$692236 \quad 5.5644 E-05$

$6922382.2086 \mathrm{E}-02$

$932373.0609 E-06$

$94238 \quad 3.2259 E-07$

$694239 \quad 9.7367 \mathrm{E}-05$

$694240 \quad 1.5590 \mathrm{E}-05$

$694241 \quad 7.5033 \mathrm{E}-06$

$94242 \quad 6.4014 E-07$

$952412.5006 \mathrm{E}-07$

$95243 \quad 4.3789 E-08$

$96244 \quad 3.0823 E-09$

8016 4.6253E-02

$36083 \quad 1.3575 E-06$

40093 1.1554E-05

$42095 \quad 1.6411 E-05$

43099 1.7533E-05

$44101 \quad 1.5536 E-05$

$44103 \quad 1.4816 E-07$

$45103 \quad 1.0070 \mathrm{E}-05$

$45105 \quad 9.4277 \mathrm{E}-36$

$46105 \quad 5.3360 \mathrm{E}-06$

$46108 \quad 1.3348 E-06$

$47109 \quad 9.4779 \mathrm{E}-07$ 


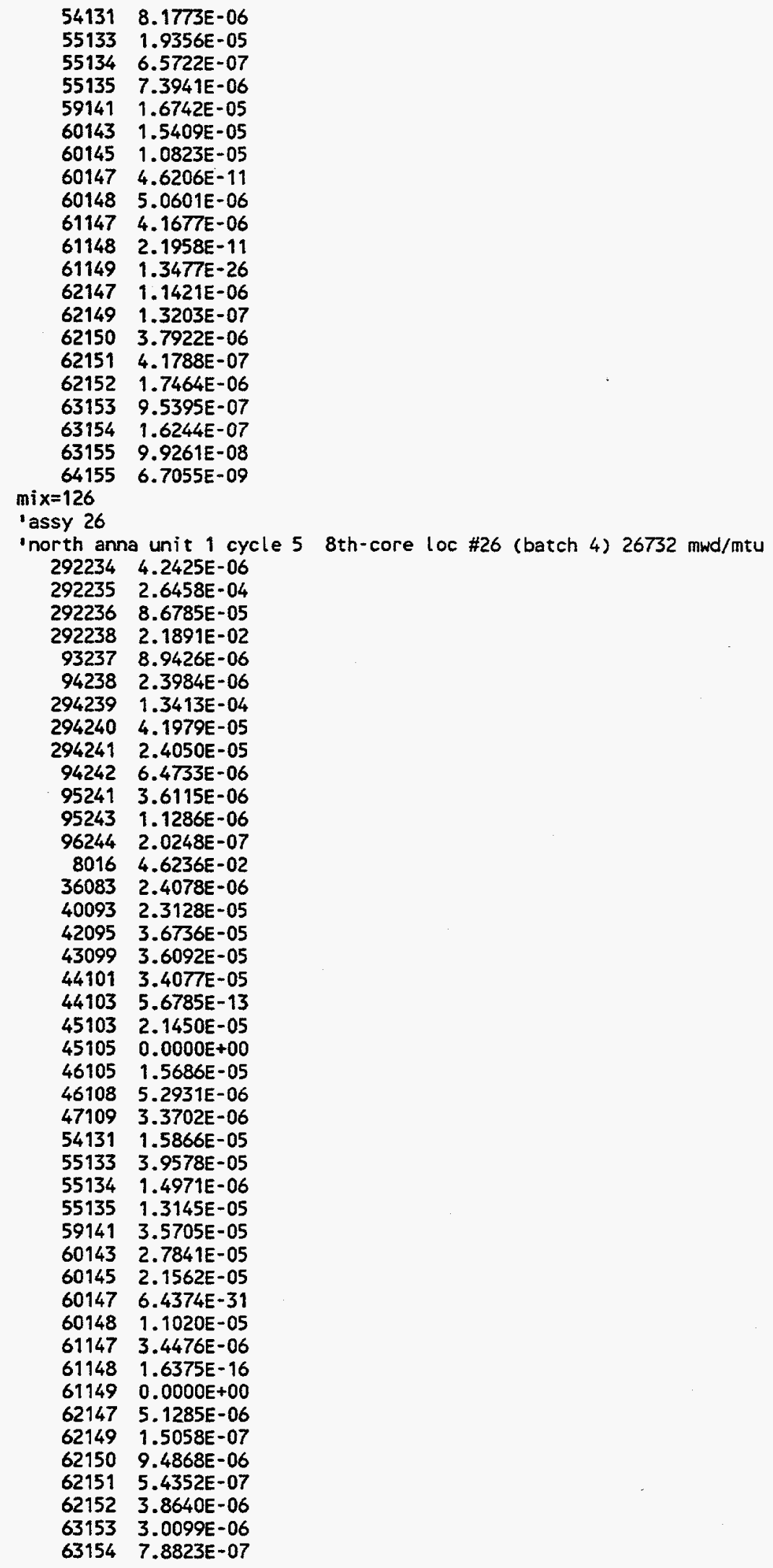




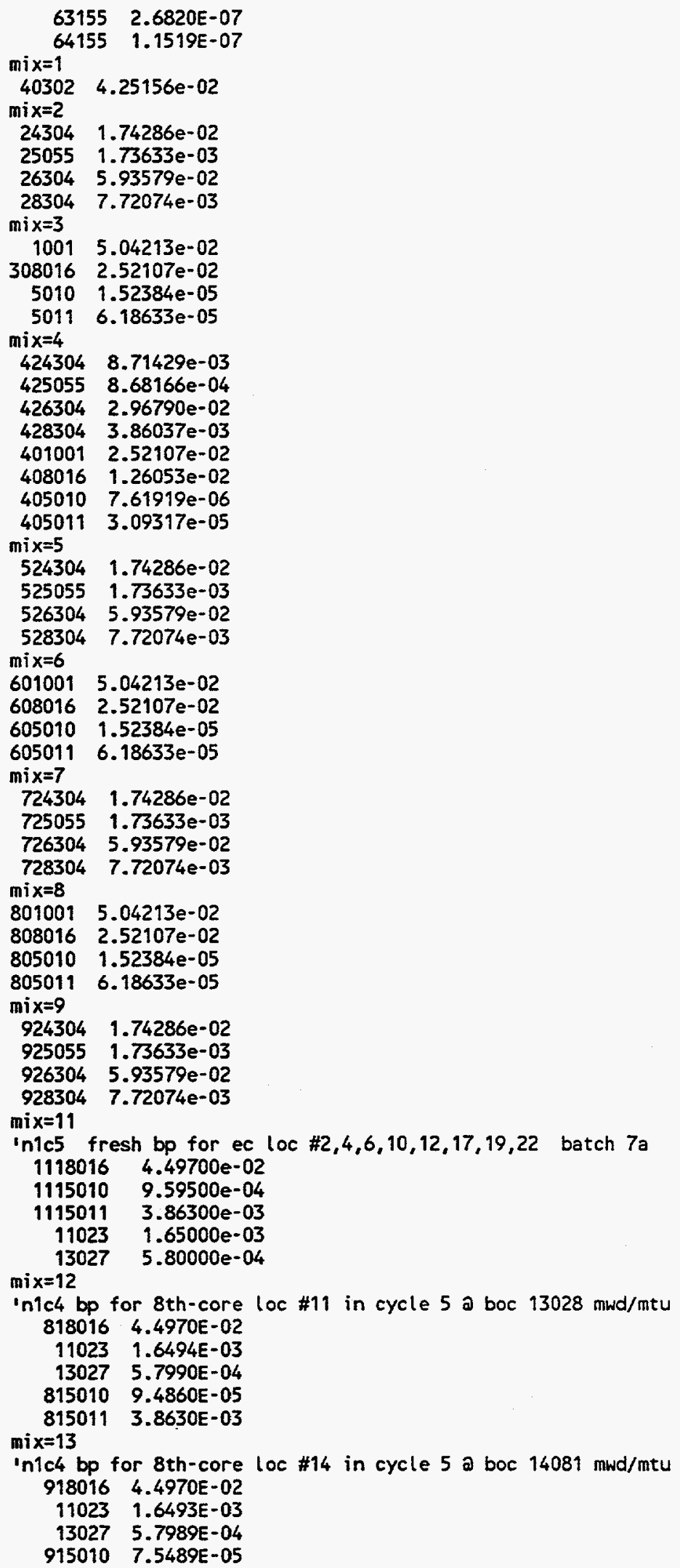




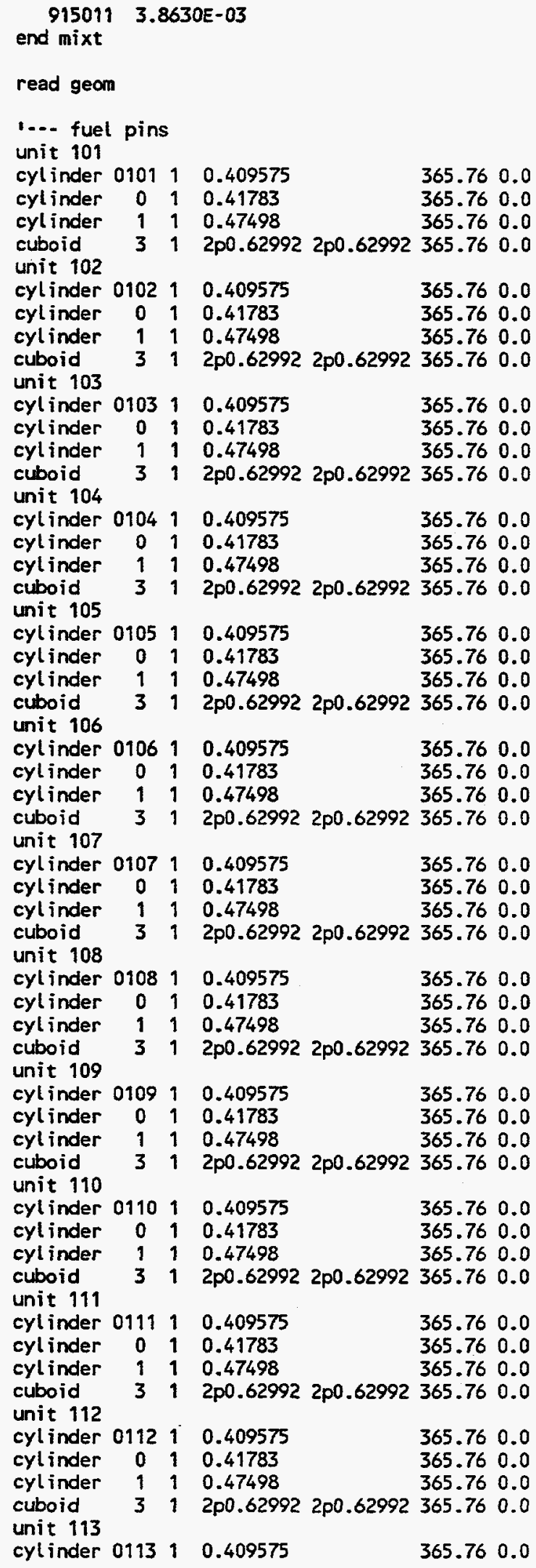




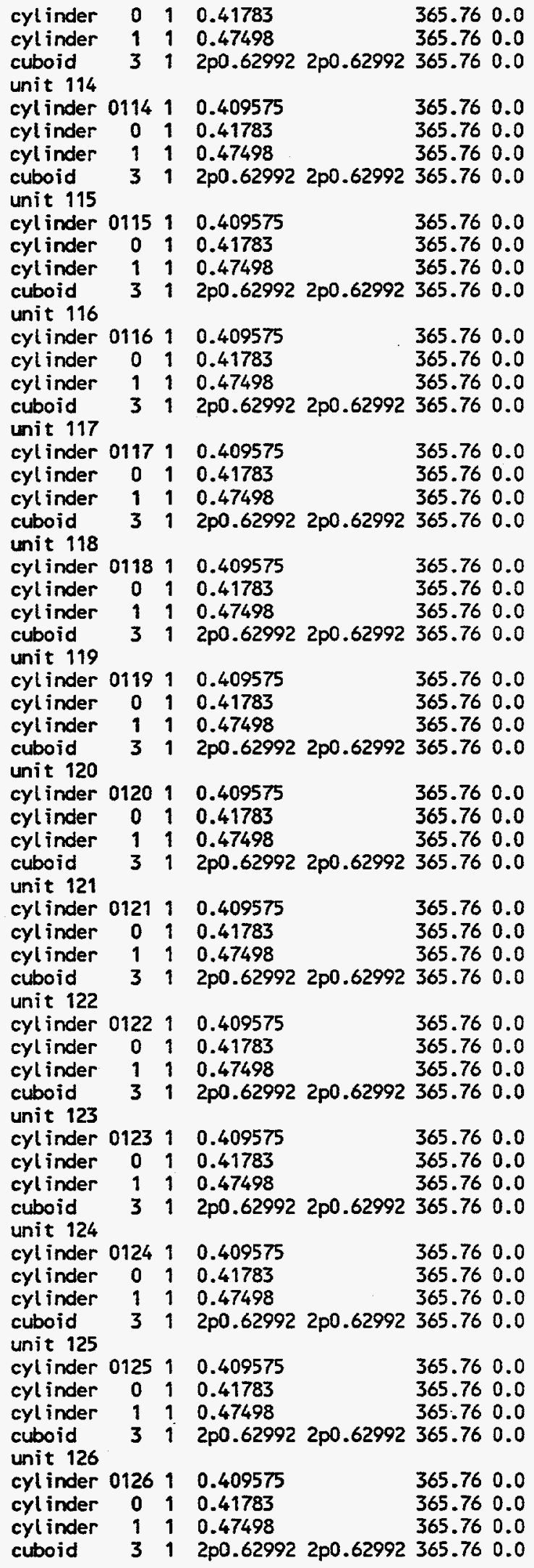




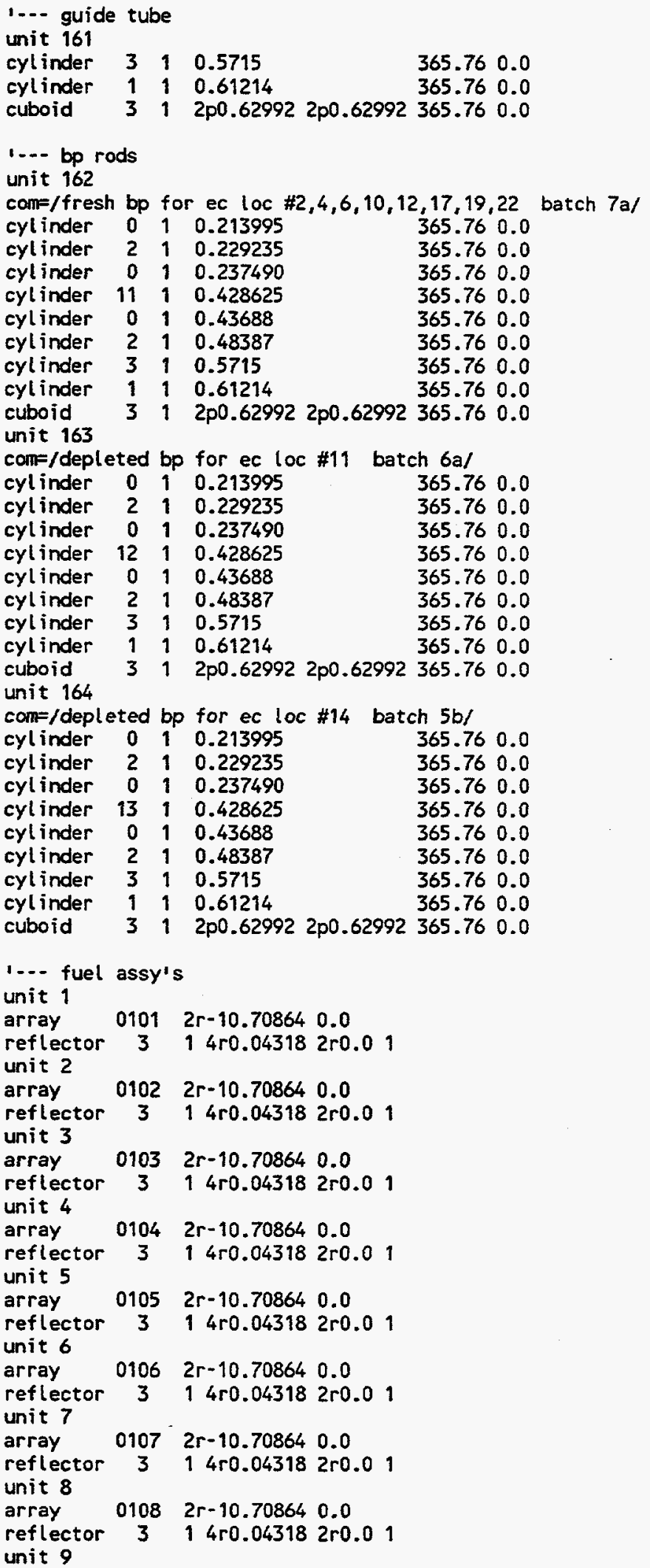




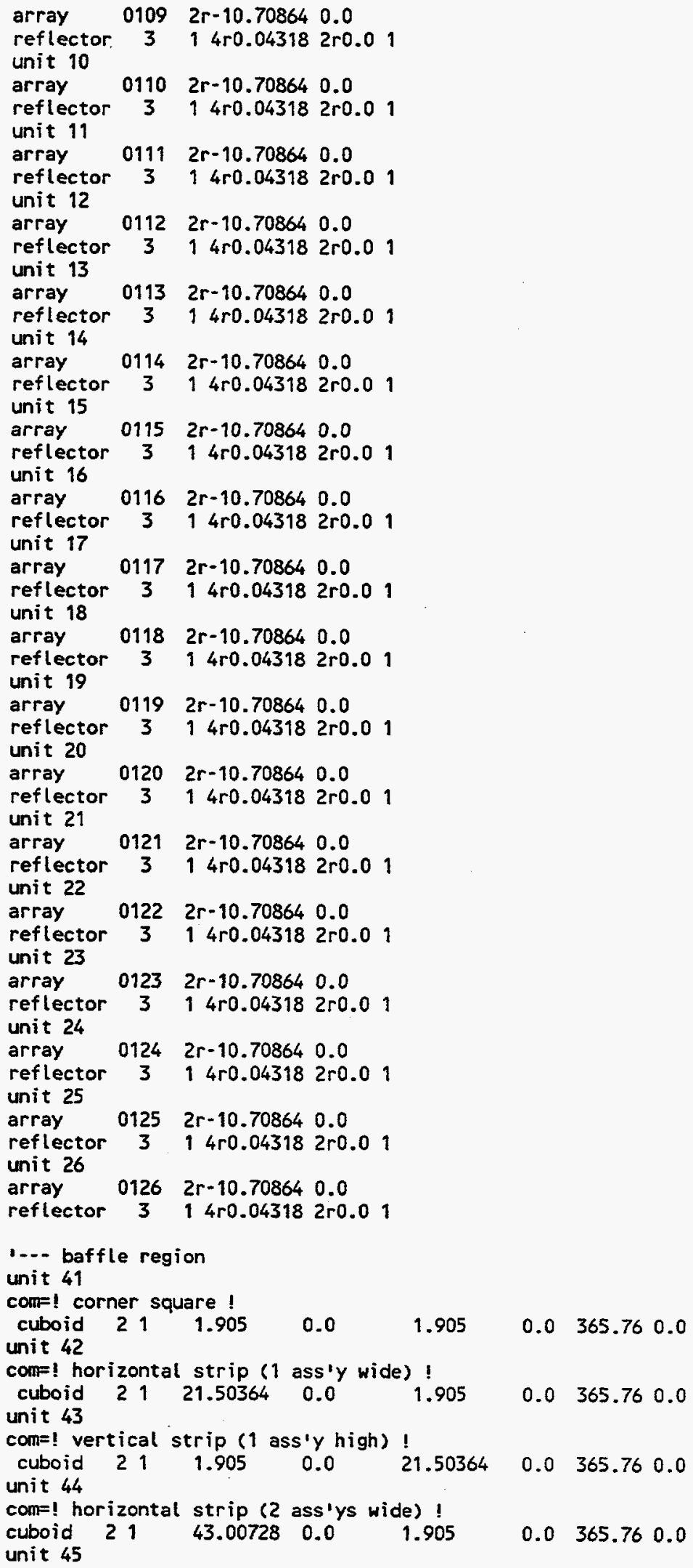


com=! horizontal strip (1 ass'y wide) bottom of $y$ axis !

$\begin{array}{lllllll}\text { cuboid } 21 & 21.50364 & 0.0 & 0.0 & -1.905365 .76 & 0.0\end{array}$

unit 46

com=! horizontal strip (2 ass'ys wide) bottom of $y$ axis !

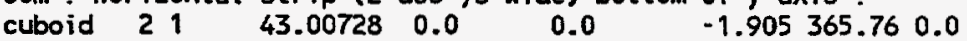

---rows of assy's w/ baffle regions on each end

unit 51

com=! row 1 !

array $1-34.16046-12.656820 .0$

unit 52

con=! row 2 !

$\begin{array}{llll}\text { array } 2 & -77.16774 & -10.75182 & 0.0\end{array}$

unit 53

com $=$ ! row 3 !

$\begin{array}{lllll}\text { array } 3 & -98.67138 & -10.75182 & 0.0\end{array}$

unit 54

con=! row 4 !

array $4-120.17502-10.751820 .0$

unit $\mathbf{5 5}$

com=! rows $5 \& 6$ !

array $5-141.67866-21.503640 .0$

unit 57

com $=1$ rows $7-9$ !

array $7-163.18230-32.25546 \quad 0.0$

unit 60

compl rows $10 \& 11$ !

array $10-141.67866-21.503640 .0$

unit 62

com=! row 12 !

array $12-120.17502-10.751820 .0$

unit 63

compl row 13 !

array $13 \quad-98.67138 \quad-10.75182 \quad 0.0$

unit 64

com=! row 14 !

$\begin{array}{llll}\text { array } 14 & -77.16774 & -10.75182 & 0.0\end{array}$

unit 65

com=! row 15 !

array $15 \quad-34.16046-10.75182 \quad 0.0$

global unit 70

cylinder 31170.02125365 .760 .0

hole $57 \quad 0.0 \quad 0.0 \quad 0.0$

hole $\begin{array}{llll}55 & 0.0 & -53.75911 & 0.0\end{array}$

hole $60 \quad 0.0 \quad 53.759110 .0$

hole $\begin{array}{lllll}54 & 0.0 & -86.01458 & 0.0\end{array}$

hole $\begin{array}{llll}62 & 0.0 & 86.01458 & 0.0\end{array}$

hole $\begin{array}{lllll}53 & 0.0 & -107.51823 & 0.0\end{array}$

hole $63 \quad 0.0 \quad 107.51823 \quad 0.0$

hole $52 \quad 0.0 \quad-129.02188 \quad 0.0$

hole $\begin{array}{lllll}64 & 0.0 & 129.02188 & 0.0\end{array}$

hole $51 \quad 0.0 \quad-150.52553 \quad 0.0$

hole $\begin{array}{llll}65 & 0.0 & 150.52553 & 0.0\end{array}$

hole $44-77.16775 \quad 139.773710$

hole $\begin{array}{lllll}46 & -77.16775 & -139.77471 \quad 0\end{array}$

hole $44 \quad 34.16047 \quad 139.773710$

hole $46 \quad 34.16047-139.774710$

hole $42 \quad-98.67139 \quad 118.27006 \quad 0$

hole $45-98.67139-118.27006 \quad 0$

hole $\begin{array}{lllll}42 & 77.16776 & 118.27006 & 0\end{array}$

hole $45 \quad 77.16776-118.27006 \quad 0$

hole $42-120.17503 \quad 96.766410$

hole $45-120.17503-96.767410$

hole $42 \quad 98.67140 \quad 96.76641 \quad 0$

hole $\begin{array}{llll}45 & 98.67140 & -96.76741 & 0\end{array}$

hole $42-141.67867 \quad 75.26276$

hole $45-141.67867-75.26276 \quad 0$ 


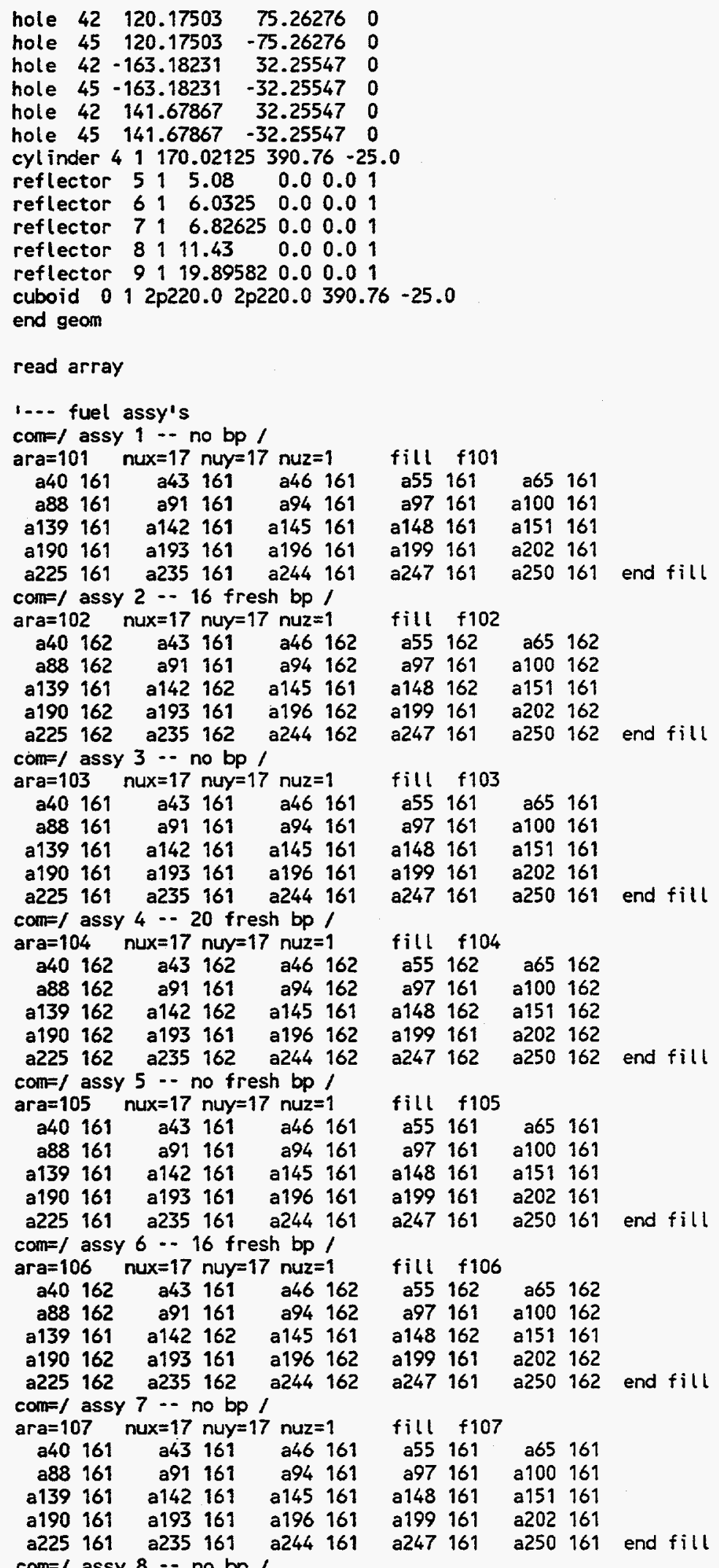




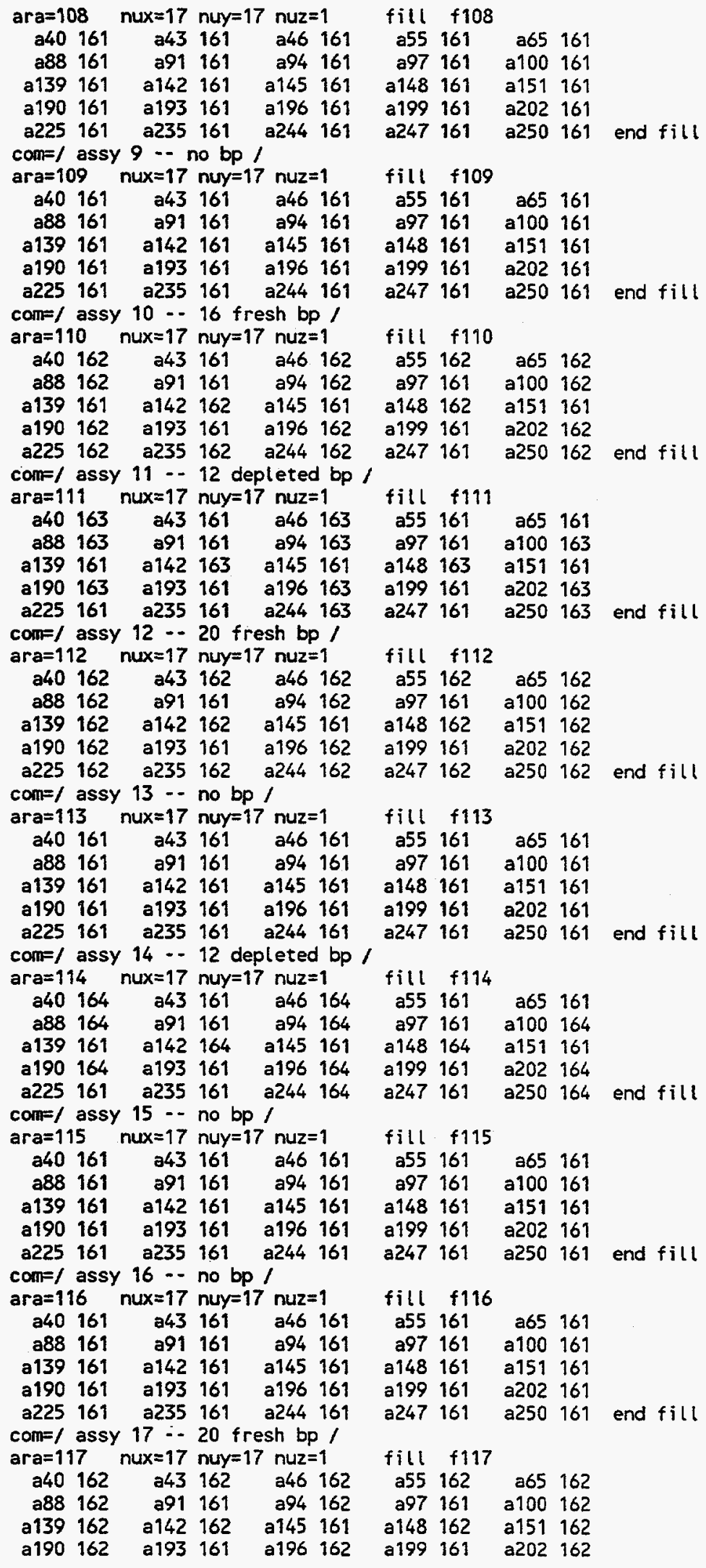




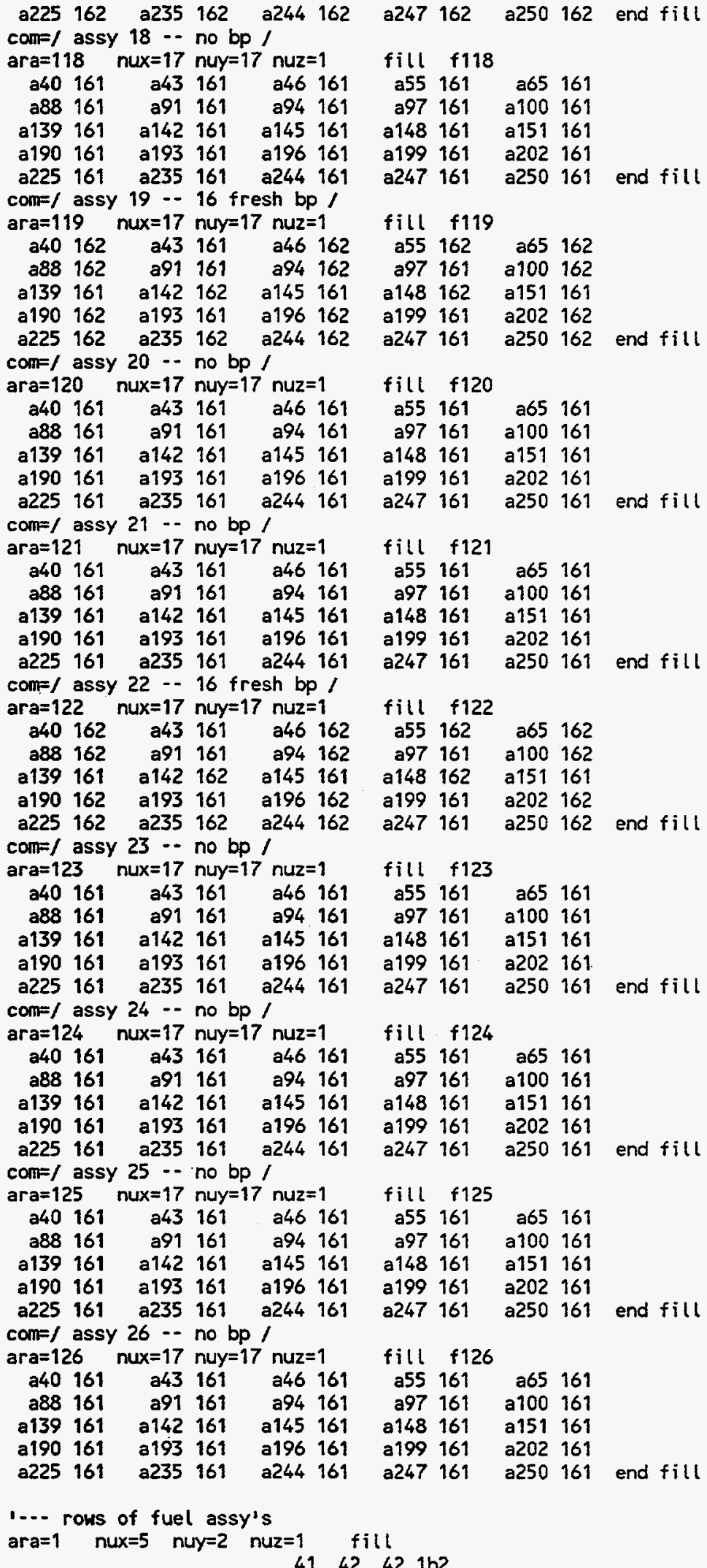




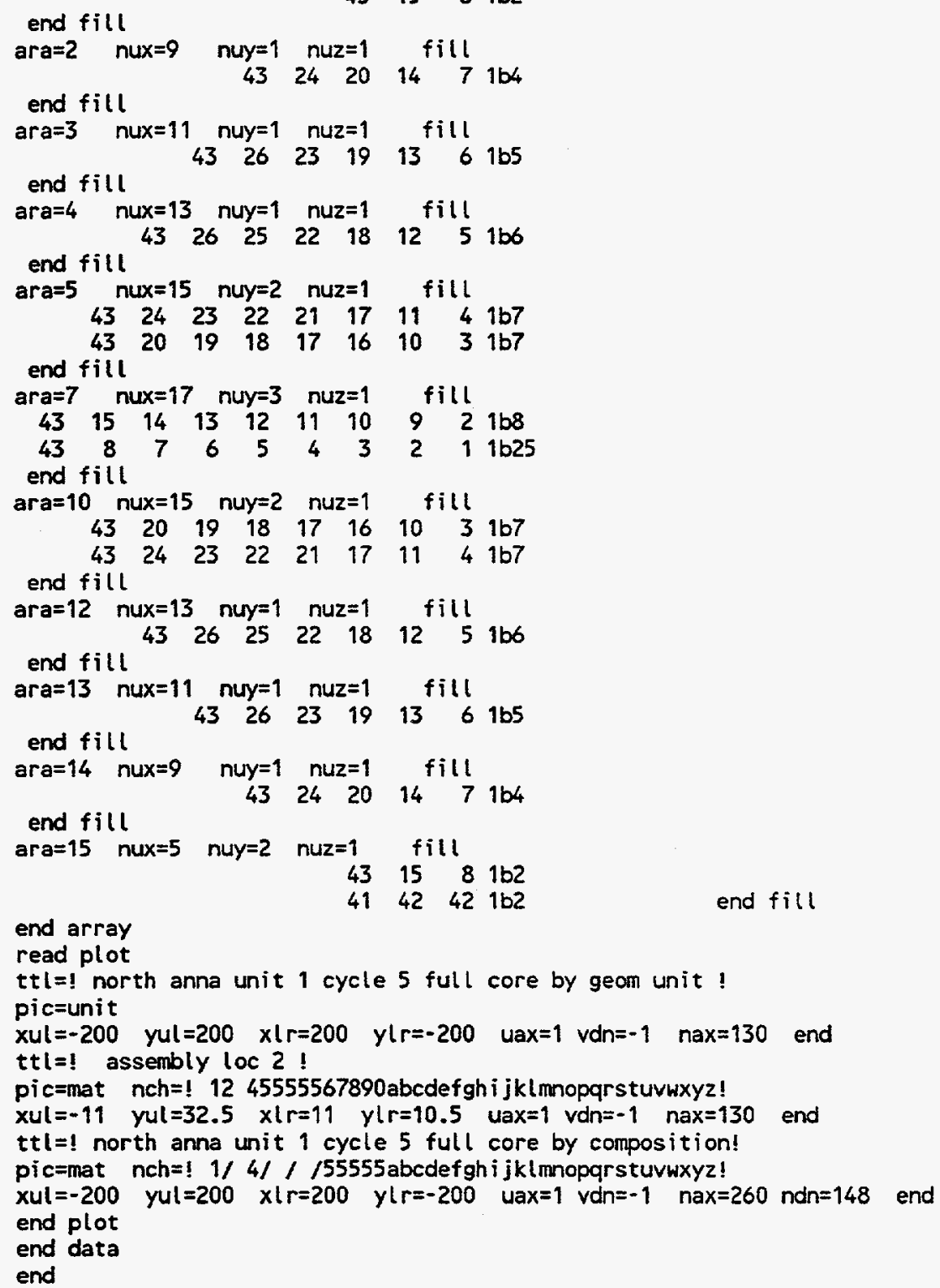

end array

read plot

ttl=! north anna unit 1 cycle 5 full core by geom unit !

pic=unit

xul $=-200$ yul $=200 \quad x l r=200 \quad y l r=-200$ uax $=1 \quad$ dnn=-1 nax=130 end

ttl $=$ ! assembly loc 2 !

pic=mat nch=! $12 \quad 45555567890$ abcdefgh i jklmnopqrstuvwxyz!

$x u l=-11$ yul=32.5 $x / r=11 \quad y l r=10.5$ uax=1 vdn=-1 nax=130 end

$t t l=!$ north anna unit 1 cycle 5 full core by composition!

pic=mat $n c h=! 1 / 4 / / / 55555$ abedefghijklmnopgrstuvwxyz!

xul $=-200$ yul $=200 \quad x l r=200 \quad$ y $l r=-200 \quad$ uax $=1 \quad$ vdn=-1 nax $=260$ ndn=148 end end plot

end data

end 
ORNL/TM-12294/V2

\section{INTERNAL DISTRIBUTION}

1. C. W. Alexander

2-3. S. M. Bowman

4. B. L. Broadhead

5. J. A. Bucholz

6. R. D. Dabbs

7-8. M. D. DeHart

9. M. B. Emmett

10. N. M. Greene

11. O. W. Hermann

12. M. Kuliasha

13. L. C. Leal

14. S. B. Ludwig

15. S. K. Martin

16. G. E. Michaels

17. B. D. Murphy

18-22. L. F. Norris

23. J. V. Pace
24-28. C. V. Parks
29. L. M. Petrie
30. R. T. Primm
31. J.-P. Renier
32. J. W. Roddy
33. R. W. Roussin
34. J. C. Ryman
35. C. H. Shappert
36. R. M. Westfall
37. B. A. Worley
38. R. Q. Wright
39-40. Laboratory Records Dept.
41. Laboratory Records, ORNL-RC
42. ORNL Y-12 Research Library
43. Central Research Library
Document Reference Section
44. ORNL Patent Section

\section{EXTERNAL DISTRIBUTION}

45. R. Anderson, General Nuclear Systems, Inc., 220 Stoneridge Dr., Columbia, SC 29210

46. M. G. Bailey, Office of Nuclear Material Safety \& Safeguards, U.S. Nuclear Regulatory Commission, MS TWFN 8F5, Washington, DC 20555

47. L. Barrett, Office of Civilian Radioactive Waste Management, RW-232 20545, U.S. Department of Energy, Washington, DC 20545

48. P. Baylor, Office of Civilian Radioactive Waste Management, RW-36, U.S. Department of Energy, Washington, DC 20545

49. C. J. Benson, Bettis Atomic Power Laboratory, P.O. Box 79, West Mifflin, PA 15122

50. J. Bickel, U.S. Department of Energy, Albuquerque Operations Office, P.O. Box 5400, Albuquerque, NM 87115

51. L. Blalock, U.S. Department of Energy, M-261 Quince Orchard, Washington, DC 205850002

52. J. Boshoven, GA Technologies, Inc., P.O. Box 85608,10955 John J. Hopkins Dr., San Diego, CA 92121

53. M. C. Brady, Sandia National Laboratories, 101 Convention Center Drive, Suite 880, Las Vegas, NV 89109

54. P. Bunton, U.S. Department of Energy, RW-1, Washington, DC 20545 
55. R. J. Cacciapouti, Yankee Atomic Electric Co., 1617 Worcester Rd., Framington, MA 01701

56. R. Carlson, Lawrence Livermore National Laboratory, P.O. Box 808, Livermore, CA 94550

57. C. R. Chappell, U.S. Nuclear Regulatory Commission, Office of Nuclear Materials Safety and Safeguards, TWFN 8F5, Washington, DC 20555

58. J. S. Choi, Lawrence Livermore National Laboratory, P.O. Box 808, Livermore, CA 94550

59. J. Clark, 2650 Park Tower Drive, Suite 800, Vienna, VA 22180

60. J. Conde, Consejo de Seguridad Nuclear, Justo Dorado, 11, 28040 Madrid, Spain

61. D. R. Conners, Bettis Atomic Power Laboratory, P.O. Box 79, West Mifflin, PA 15122

62. M. Conroy, U.S. Department of Energy, M-261 Quince Orchard, Washington, DC 20585-0002

63. P. J. Cooper, Sandia National Laboratories, P.O. Box 5800, Albuquerque, NM 871850716

64. W. Davidson, Los Alamos National Laboratory, Group A4, MSF-61 1, Los Alamos, NM 87845

65-67. F. J. Davis, Sandia National Laboratories, P.O. Box 5800, Div. 6302, MS 1333, Albuquerque, NM 87185-0716

68. D. Dawson, Transnuclear, Inc., 2 Skyline Dr., Hawthorne, NY 10532-2120

69. T. W. Doering, TESS, B\&W Fuel Co., MS 423, Suite 527, P.O. Box 98608, 101 Convention Center Drive, Las Vegas, NV 89109

70. R. Doman, Nuclear Packaging, Inc., 1010 S. 336th St., Suite 220, Federal Way, WA 98003

71. E. Easton, U.S. Nuclear Regulatory Commission, Office of Nuclear Materials Safety and Safeguards, Washington, DC 20555

72. R. C. Ewing, Sandia National Laboratories, P.O. Box 5800, Div. 6643, MS 0716, Albuquerque, NM 87185-0716

73. C. Garcia, U.S. Department of Energy, Albuquerque Operations Office, P.O. Box 5400, Albuquerque, NM 87115

74. S. Hanauer, U.S. Department of Energy, RW-22, Washington, DC 20545

75. C. Haughney, U.S. Nuclear Regulatory Commission, Office of Nuclear Materials Safety and Safeguards, TWFN 8F5, Washington, DC 20555

76. L. Hassler, Babcock \& Wilcox, P.O. Box 10935, Lynchburg, VA 24506-0935

77. E. Johnson, E. R. Johnson Associates, Inc., 9302 Lee Hwy, Suite 200, Fairfax, VA 22031

78. R. Kelleher, International Atomic Energy Agency, Division of Publications, Wagramerstrasse 5, P.O. Box 100, Vienna, Austria A-1400

79. R. Kidman, Los Alamos National Laboratory, Group A4, MSF-611, Los Alamos, NM 87845

80. C. Kouts, Office of Civilian Radioactive Waste Management, RW-36, U.S. Department of Energy, Washington, DC 20545

81. S. Kraft, Nuclear Energy Institute, 1776 I Street, Suite 400, Washington, DC 20086 
82. P. Krishna, TRW Environmental Safety Systems, 600 Maryland Ave. S.W., Suite 695, Washington, DC 20024

83. A. Kubo, 2650 Park Tower Drive, Suite 800, Vienna, VA 22180

84. W. H. Lake, Office of Civilian Radioactive Waste Management, U.S. Department of Energy, RW-46, Washington, DC 20585

85-87. R. Lambert, Electric Power Research Institute, 3412 Hillview Ave., Palo Alto, CA 94304

88-90. D. Lancaster, 2650 Park Tower Drive, Suite 800, Vienna, VA 22180

91. D. Langstaff, U.S. Department of Energy, Richland Operations Office, P.O. Box 550, Richland, WA 99352

92. D. Lillian, U.S. Department of Energy, M-261 Quince Orchard, Washington, DC 205850002

93. C. Marotta, 1504 Columbia Ave., Rockville, MD 20850

94. M. Mason, Transnuclear, Two Skyline Drive, Hawthorne, NY 10532-2120

95. J. Massey, Sierra Nuclear Corporation, 5619 Scotts Valley Drive, Number 240, Scotts Valley, CA 95066

96. W. Mings, U.S. Department of Energy, Idaho Operations Office, 550 2nd St., Idaho Falls, ID 83401

97. A. Mobashevan, Roy F. Weston, Inc., 955 L'Enfant Plaza, SW, 8th Floor, Washington, DC 20024

98. R. Morgan, 2650 Park Tower Drive, Suite 800 , Vienna, VA 22180

99. P. K. Nair, Manager, Engineered Barrier System, Center for Nuclear Waste Regulatory Analyses, Southwest Research Institute, 6220 Culebra Road, San Antonio, TX 782385166

100. D. Napolitano, Nuclear Assurance Corp., 5720 Peachtree Parkway, Norcross, GA 30092

101. C. W. Nilsen, Office of Nuclear Material Safety and Safeguards, U.S. Nuclear Regulatory Commission, MS TWFN-9F29, Washington, DC 20555

102. D. J. Nolan, 2650 Park Tower Drive, Suite 800 , Vienna, VA 22180

103-104. Office of Scientific and Technical Information, U.S. Department of Energy, P.O. Box 62, Oak Ridge, TN 37831

105. Office of the ORNL Site Manager, Department of Energy, ORNL, P.O. Box 2008, Oak Ridge, TN 37831-6269

106. C. E. Olson, Sandia National Laboratories, P.O. Box 5800, Div. 6631, MS 0715 , Albuquerque, NM 87185-0716

107. N. Osgood, U.S. Nuclear Regulatory Commission, Office of Nuclear Materials Safety and Safeguards, TWFN 8F5, Washington, DC 20555

108. O. Ozer, Electric Power Research Institute, 3412 Hillview Ave., Palo Alto, CA 94304

109. P. Pacquin, General Nuclear Systems, Inc., 220 Stoneridge Dr., Columbia, SC 29210

110. T. Parish, Department of Nuclear Engineering, Texas A \& M University, College Station, TX 77843-3313

111-113. M. Rahimi, 2650 Park Tower Drive, Suite 800, Vienna, VA 22180

114. B. Rasmussen, Duke Power Co., P.O. Box 33189, Charlotte, NC 28242

115. T. L. Sanders, Sandia National Laboratories, P.O. Box 5800, Div. 6609, MS 0720, Albuquerque, NM 87185-0716 
116. K. D. Seager, Sandia National Laboratories, P.O. Box 5800, Div. 6643, MS 0716, Albuquerque, NM 87185-0716

117. M. Smith, U.S. Department of Energy, Yucca Mountain Project Office, 101 Convention Center Dr., Las Vegas, NV 89190

118. M. Smith, Virginia Power Co., P.O. Box 2666, Richmond, VA 23261

119. K. B. Sorenson, Sandia National Laboratories, P.O. Box 5800, Div. 6643, MS 0716, Albuquerque, NM 87185-0716

120. F. C. Sturz, Office of Nuclear Material Safety \& Safeguards, U.S. Nuclear Regulatory Commission, MS TWFN 8F5, Washington, DC 20555

121. J. Sun, Florida Power \& Light Co., P.O. Box 029100, Miami, FL 33102

122. T. Suto, Power Reactor and Nuclear Fuel Development Corp., 1-9-13, Akasaka, Minato$\mathrm{Ku}$, Tokyo, Japan

123. R. J. Talbert, Battelle Pacific Northwest Laboratory, P.O. Box 999, Richland, WA 99352

124. T. Taylor, INEL, P.O. Box 4000 , MS 3428, Idaho Falls, ID 83403

125. B. Thomas, VECTRA Technologies, Inc., 6203 San Ignacio Ave., Suite 100, San Jose, CA 95119

126. D. A. Thomas, B\&W Fuel Co., 101 Convention Center Drive, Suite 527, MS 423, Las Vegas, NV 89109

127. J. R. Thornton, TRW Enviornmental Safety Systems, 2650 Park Tower Dr., Suite 800, Vienna, VA 22180

128. G. Walden, Duke Power Co., P.O. Box 33189, Charlotte, NC 28242

129. M. E. Wangler, U.S. Department of Energy, EH-33.2, Washington, DC 20585-0002

130. R. Weller, U.S. Nuclear Regulatory Commission, TWFN 7J9, Washington, DC 20555

131. A. Wells, 2846 Peachtree Walk, Duluth, GA 30136

132. W. Weyer, Wissenschaftlich-Technische Ingenieurberatung GMBH, Mozartstrasse 13, 5177 Titz-Rodingen, Federal Republic of Germany

133. B. H. White, Office of Nuclear Material Safety \& Safeguards, U.S. Nuclear Regulatory Commission, MS TWFN 8F5, Washington, DC 20555

134. J. Williams, Office of Civilian Radioactive Waste Management, U.S. Department of Energy, RW-46, Washington, DC 20545

135. M. L. Williams, LSU Nuclear Science Center, Baton Rouge, LA 70803

136. C. J. Withee, Office of Nuclear Material Safety \& Safeguards, U.S. Nuclear Regulatory Commission, MS TWFN 8F5, Washington, DC 20555

137. R. Yang, Electric Power Research Institute, 3412 Hillview Ave., Palo Alto, CA 94304 